\title{
Apresentação e Sincronização Multimídia no Ambiente SMmD
}

\author{
Laércio Augusto Baldochi Júnior
}

Orientadora

Prof ${ }^{\text {. }}$. Dr ${ }^{\mathrm{a}}$. Maria da Graça Campos Pimentel

\begin{abstract}
Dissertação ${ }^{1}$ apresentada ao Instituto de Ciências Matemáticas e de Computação, da Universidade de São Paulo - USP, como parte dos requisitos para obtenção do título de Mestre em Ciências - Área: Ciências da Computação e Matemática Computacional.
\end{abstract}

São Carlos, outubro de 1998

\footnotetext{
${ }^{1}$ Trabalho realizado com apoio financeiro da FAPESP, e, no contexto do Projeto SMmD, do ProTeM-CC/CNPq
} 
. 
"Há três coisas que nunca voltam atrás:

a flecha lançada, a palavra pronunciada e a oportunidade perdida." Provérbio chinês

"É melhor estar preparado para uma oportunidade e não ter nenhuma, do que ter uma oportunidade e não estar preparado." Whitney Young Jr. 
A Deus, pela vida e pelas oportunidades.

À minha mãe, Jaira, que sempre me apoiou incondicionalmente.

À minha irmã, Cidinha. Sem sua ajuda eu não teria chegado até aqui.

À Sílvia e Sandra, irmãs que, mesmo distantes, sempre mantiveram o elo fraterno que nos une.

À Rose, pelo incentivo, afeto e dedicação.

À Profa. Graça, por acreditar em meu potencial.

Aos amigos Luis Carlos e Daniel, companheiros de república, mestrado, festas, enfim, de todos os bons momentos vividos em São Carlos.

Aos amigos da pós-graduação, pelo companheirismo e amizade que tornaram as adversidades do mestrado mais amenas.

Ao pessoal do Laboratório Intermídia, pela ajuda inestimável na fase de implementação do meu trabalho.

Aos docentes e funcionários do ICMC-USP, que trabalham incansavelmente para fazer desse Instituto um centro de excelência em pesquisa e ensino na área da computação.

À FAPESP, pelo auxílio concedido, e a todos que de alguma forma tornaram este trabalho possível. 
2.1. CONSIDERAÇÕES INICIAIS .5

2.2. CLASSIFICAÇÃo DE MíbIas. . .5

2.3. REPRESENTAÇÃO ESPACIAL DE MIDIAS . .7

2.4. SISTEMAS MULTIMIDIA .8

2.5. REQUISTTOS PARA UM SISTEMA DE APRESENTAÇÃO MULTIMIDIA...................................................................9

2.6. QUALIDADE DE SERVIÇO EM SISTEMAS MULTIMIDIA DISTRIBUIDOS..............................................................10

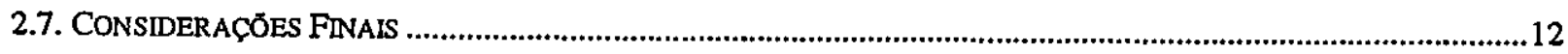

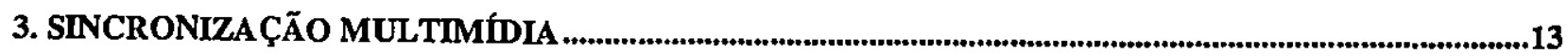

3.1. CONSIDERAÇÕES INICLAIS . .13

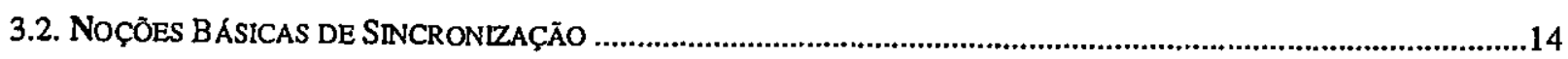

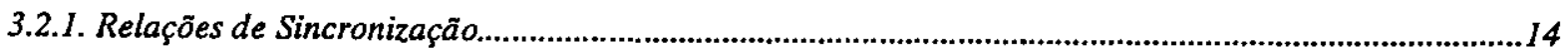

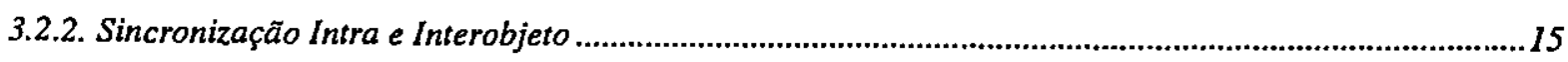

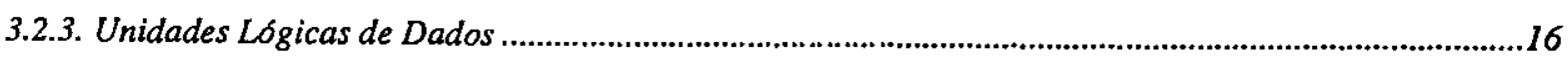

3.2.4. Especificação de Dependências Temporais....................................................................................18

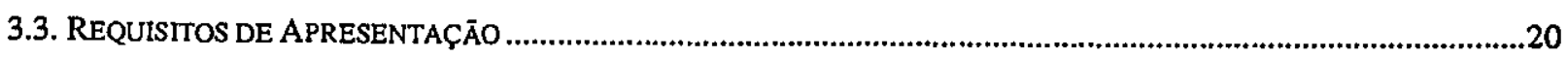

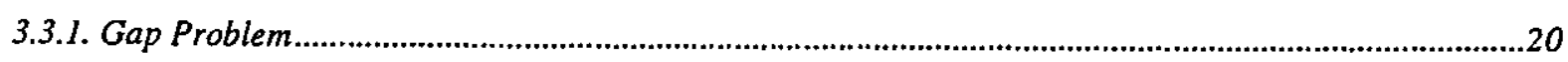

3.3.2. Sincronização Labial e Sincronização de Ponteiros...........................................................................22

3.4. MODELOS DE REFERÊNCIA PARA SINCRONIZAÇÃo MULTIMÍDIA .................................................................24

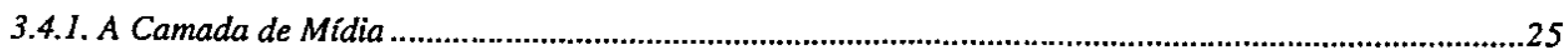

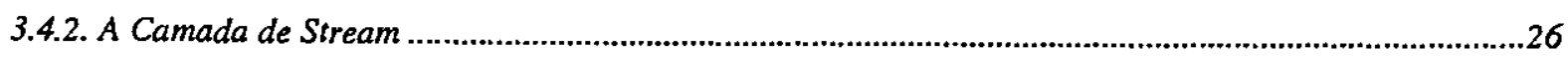

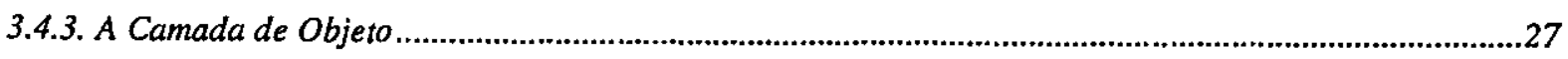

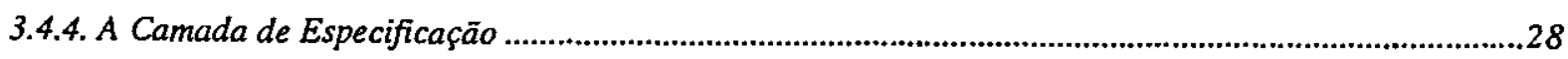

3.5. MÉTODOS DE ESPECIFICAÇÃO DE SINCRONZZAÇĀO MULTIMIDIA .................................................................29

3.5.1. Especificaçöes Baseadas em Intervalos............................................................................................29

3.5.2. Especificação de Sincronização Baseada em Eixos .............................................................................32

3.5.3. Especificação de Sincronização Baseada em Controle de Fluxo ...........................................................33

3.5.4. Especificação de Sincronização Baseada em Eventos..........................................................................34

3.6. SINCRONIZAÇÃO EM AMBIENTES DISTRIBUfDOS ......................................................................................35

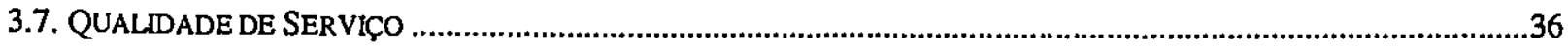

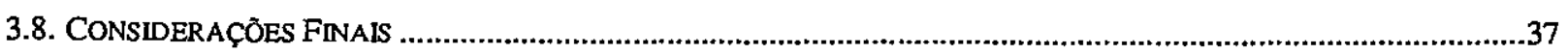




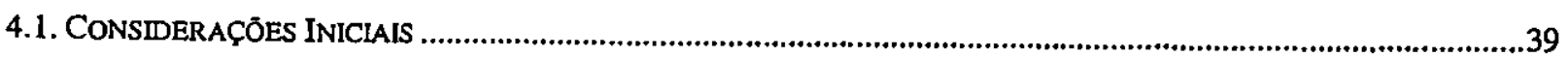

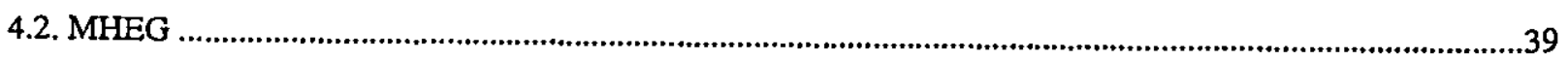

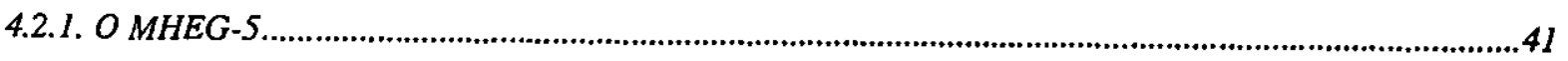

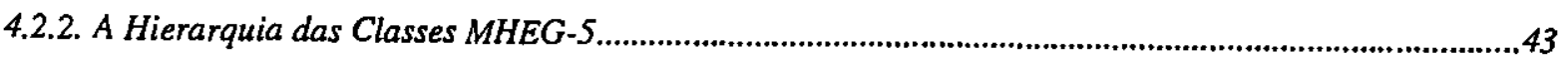

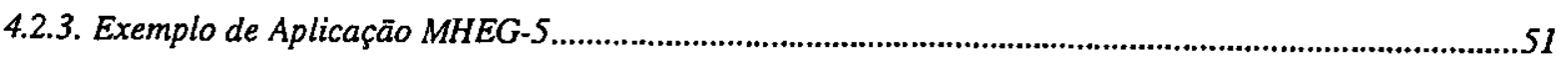

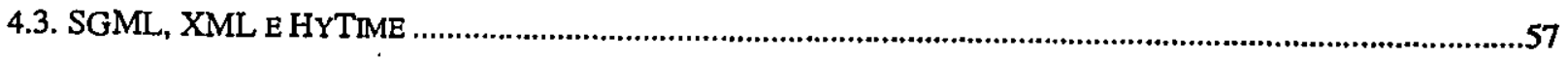

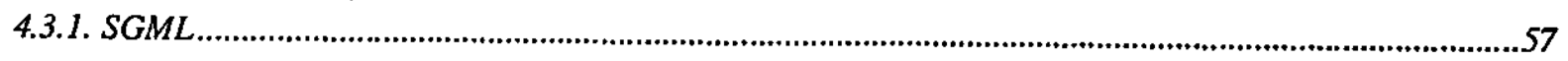



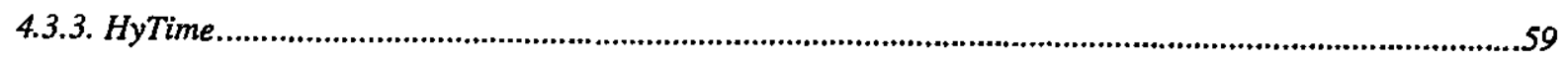

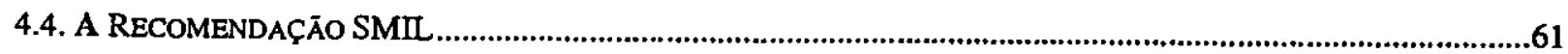

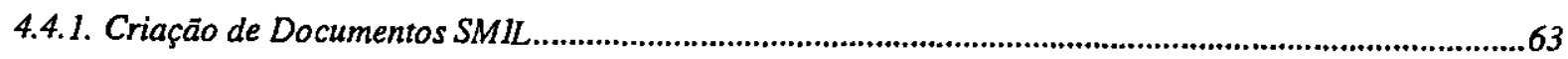

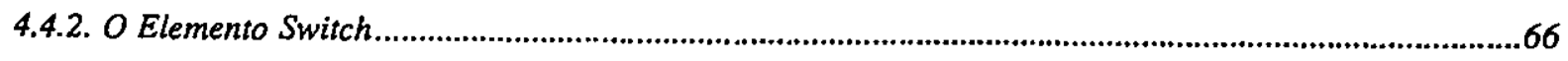

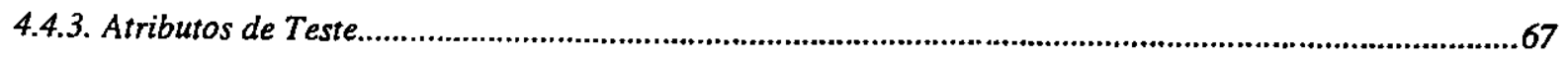

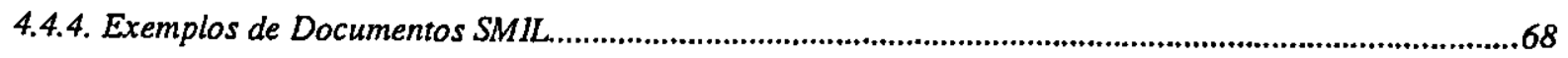

4.5. INTERSECÇÃO ENTRE OS PADRÕES MHEG E HYTMEE E A RECOMENDAÇÄO SMIL..........................................71

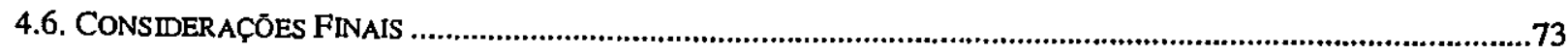

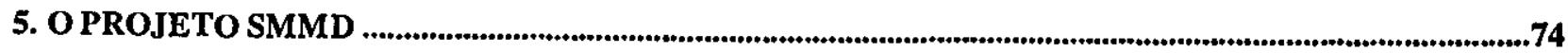

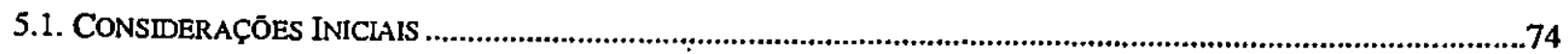

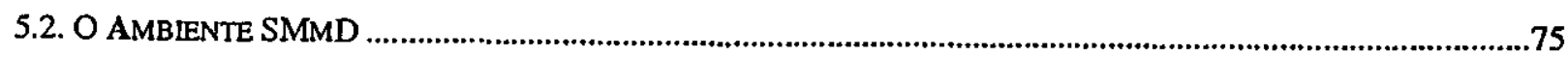

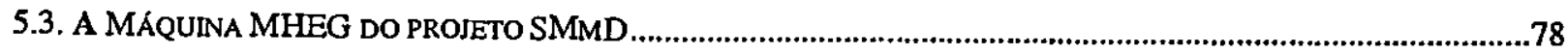

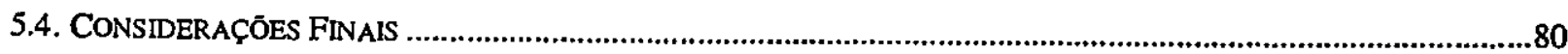

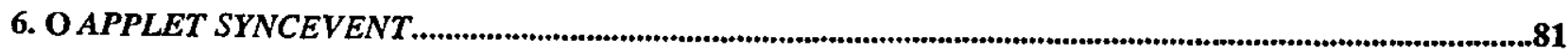

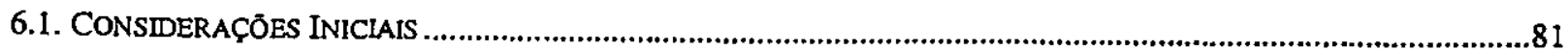

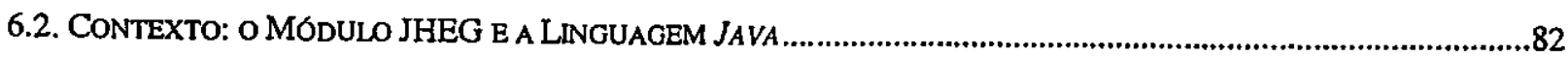

6.3. IMPLEMENTAÇÃO DAS RELAÇOES TEMPORAIS DE ALLEN ............................................................................82

6.3.1. A Primeira Versão do Applet SyncEvent ......................................................................................83

6.3.2. A Segunda Versão do Applet SyncEvent ............................................................................................86

6.4. O APPLET SYNCEVENT NO CONTEXTO DOS PADRŌES HYTIME E MHEG ......................................................89

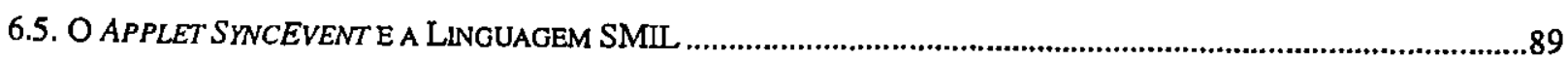

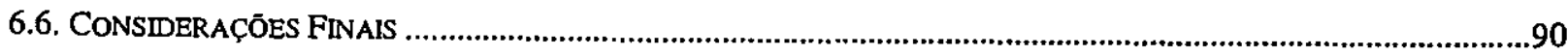

7. O MÓDULO DE APRESENTAÇÃO E SINCRONIZAÇÃO.........................................................................91

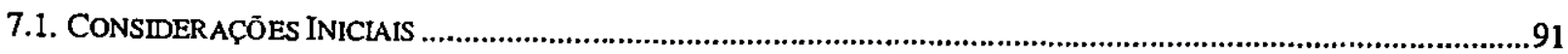

7.2. A ARQUITETURA DO MÓDULO DE APRESENTAÇĀo E SINCRONIZAÇĀO..........................................................91

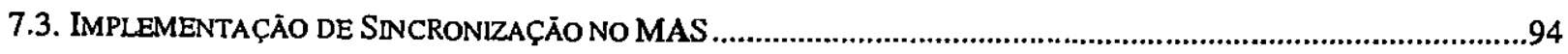

7.3.1. Especificação de Sincronização Multimidia no Padrāo MHEG-5 .......................................................94 
7.3.2. Extensāo do MHEG-5 para Suporte à Sincronizaçäo Multimídia .......................................................96

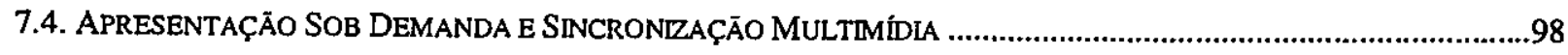

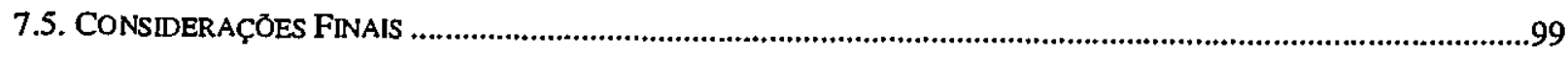

8. CONCLUSÃO

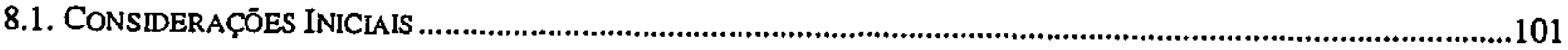

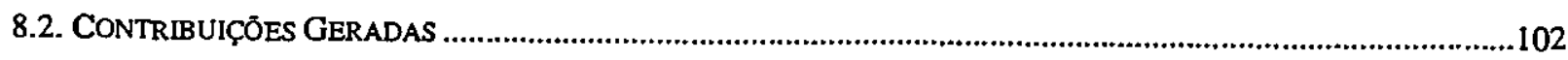

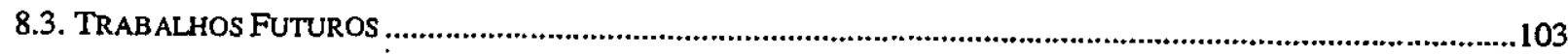

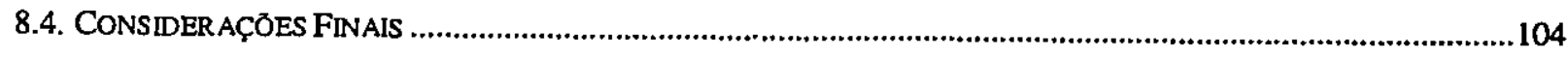

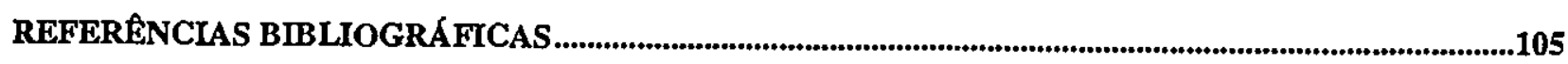

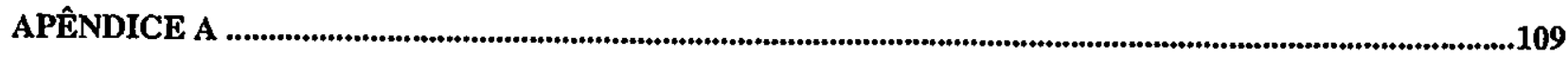

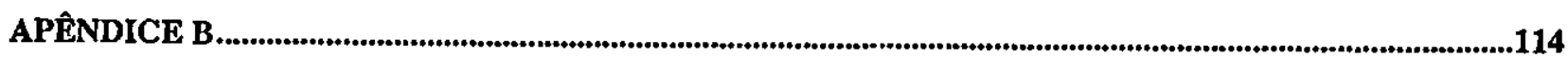


FIGURA 3.1 - SINCRONIZAÇÃO INTRA-OBJETO ENTRE FRAMES DE UMA SEQUÊNCIA DE VIDEO [SN95] .........................16

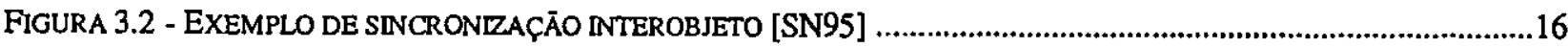

FIGURA 3.3 - VISĀo DAS ULDS DE UMA SINCRONIZAÇĀO LABIAL [SN95] .......................................................18

FIGURA 3.4 - SOlUÇÃo PARA O GAP PROBLEM ATRAVÉS do MÉTODO DE BLOQUEIO RESTRITIVO [SN95]....................21

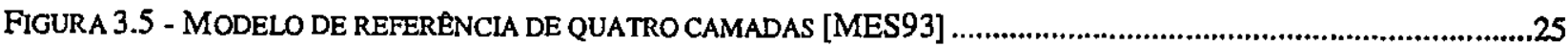

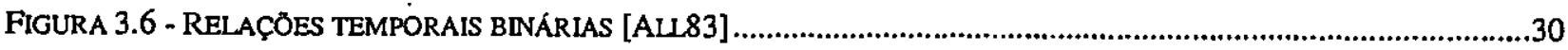

FIGURA 3.7 - OPERAÇర̃ES DO MODELO AVANÇADO DE SINCRONIZAÇÃo BASEADO EM INTERVALOS [WR94] .................31

FIGURA 4.1 - APLICAÇÃO MHEG EM UM SERVIDOR, COM PARTES CARREGADAS EM UM CLIENTE [JR95] ...................42

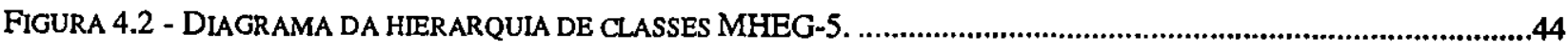

FIGURA 4.3 - RECORTE DE TELA DA APLICAÇĀO "PRODUÇĀO DE MÍDIA DiGTTAL" ..................................................52

FIGURA 4.4 - PARTE DA NOTAÇĀo TEXTUAL DA APLICAÇĀO "PRODUÇĀO DE MÍDIA DIGITAL" ...................................54

FIGURA 4.5 - USO UM VALOR DE "DELAY" DENTRODE UM ELEMENTO PAR..........................................................65

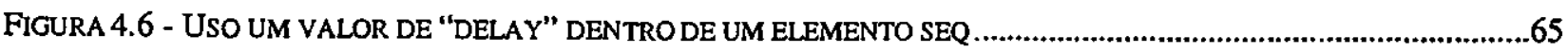

FIGURA 4.7 - ATRIBUTO DE SINCRONIZAÇĀO COM O ELEMENTO EVENT VALUE .......................................................65

FIGURA 4.8 - USO DO ELEMENTO SEQ EM UM DOCUMENTO SMIL. ........................................................................68

FIGURA 4.9 - USO DO ELEMENTO PAR EM UM DOCUMENTO SMIL . ......................................................................69

FIGURA 4.10 - USO DE ELEMENTOS PAR E SEQ INTERCALADOS EM UM DOCUMENTO SMIL ..........................................70

FIGURA 4.11 - USO DO ELEMENTO SWITCH EM UM DOCUMENTO SMIL . .....................................................................71

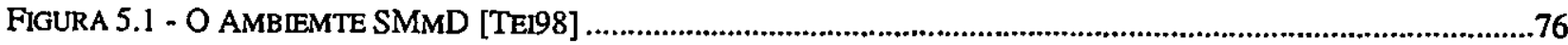

FIGURA 5.2 - MODELO DA MÁQUINA MHEG-5 DO PROJETO SMMD [TEI98] .........................................................78

FIGURA 6.1 - CÓDIGO HTML USADO NA ATIVAÇĀO DO APPLET SYNCEVENT, .............................................................8.

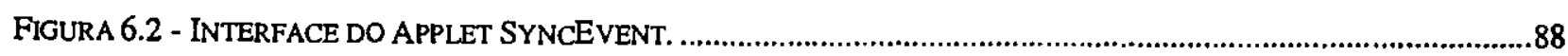

FIGURA 6.3 - TRANSFORMAÇĀo DE APLICAÇŌES SMIL EM APLICAÇర̋ES MHEG-5 E VICE-VERSA..............................90

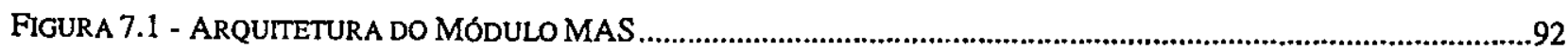

FIGURA 7.2 - EXEMPLO DO USO DA AÇĀO RUNSYNC EM UMA APLICAÇÃO MHEG-5.................................................97

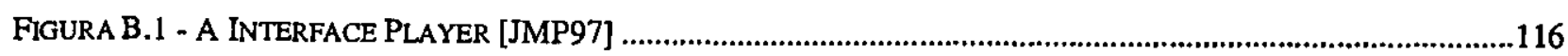

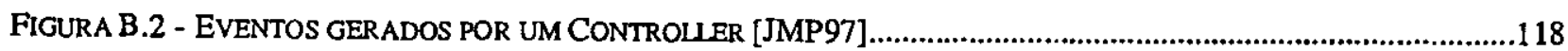

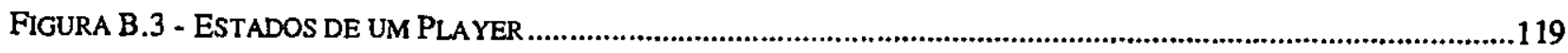

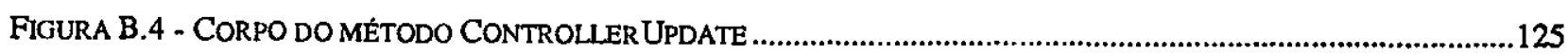

FIGURA B.5 - MAPEAMENTO ENTRE O TEMPO DE MIDIA E O TEMPO BASE [JMP97] ...................................................127 
TABELA 3.1- DEFINIÇŌES DE DEPENDENCIAS TEMPORAIS [BUF94] ....................................................................19

TABELA 3.2 - QUALIDADE DE SERVIÇO PARA PROPÓSITOS DE SINCRONIZAÇĀO [SN95] ................................................37

TABELA 4.1 - LEGENDA DO DIAGRAMA DA HIERARQUIA DE CLASSES DO PADRÃO MHEG-5 .......................................44

TABELA B.1 - RETRIÇÕES A INVOCAÇÃO DE MÉTODOS EM UM PLAYER [JMP97] .....................................................121 
O projeto SMmD - Sistemas Multimídia Distribuídos - investiga a construção de uma estrutura de middleware para dar suporte à implementação de aplicações multimídia interativas em ambientes distribuídos e heterogêneos. Para tanto, devenvolveu-se o Ambiente SMmD, o qual inclui módulos para armazenamento e recuperação de objetos de mídia tais como áudio e vídeo, e também módulos para autoria e intercâmbio de objetos multimídia em conformidade com o padrão ISO MHEG-5.

Esta dissertação descreve o trabalho de implementação de um dos módulos do Projeto SMmD, chamado Módulo de Apresentação e Sincronização (MAS). Este módulo foi implementado a partir de outro, chamado Java MHEG-5 Engine (JHEG), cuja função é interpretar e manipular objetos multimídia em conformidade com aquele padrão.

Incialmente são apresentados o contexto, a motivação e os objetivos que levaram à execução deste trabalho. A seguir, é feita uma revisão dos conceitos relacionados à apresentação multimídia, enfatizando os aspectos relacionados à sincronização de seus componentes. Em seguida, apresenta-se o padrão MHEG-5 juntamente com outros padrões e recomendações relevantes no contexto deste trabalho.

Com o objetivo de contextualizar o trabalho, é apresentada, então, uma visão geral dos módulos que compõem o Ambiente $\mathrm{SMmD}$, seguida de uma descrição do trabalho de pesquisa que resultou na implementação do applet SyncEvent, embrião do Módulo de Apresentação e Sincronização.

O Módulo de Apresentação e Sincronização, resultado principal deste trabalho, é entâo descrito, detalhando-se aspectos de sua arquitetura e de sua implementação. Finalmente, na conclusão, as contribuições deste trabalho são discutidas juntamente com suas limitações e possíveis trabalhos futuros, dentre os quais está a integração do MAS com os outros módulos do Projeto SMmD. 
The SMmD Project - Distributed Multimedia Systems - is under investigation in order to provide midleware infrastructure for multimedia interactive applications in heterogeneous distributed environments. In this context, the SMmD Environment (ASMmD) has been developed, including modules for storage and retrieval of media objects such as audio and video, as well as modules for authoring, storing and delivering multimedia objects according to the MHEG-5 ISO standard.

This dissertation describes the work relative to the implementation of the Presentation and Synchronization Module (MAS) of the SMmD Project. This module was built integrated to another module, the Java MHEG-5 Engine (JHEG), that provides the parsing and decoding of multimedia objects conforming to that ISO standard.

Initially the context, motivation and objectives are presented, followed by a literature review of concepts relative to multimedia in general and synchronization in particular. Next, the MHEG-5 standard is presented along with other standards and recommendations relevant to the context of this work.

In order to proper contextualize the work, an overview of the modules that build up the SMmD Environment is then presented, followed by a description of the investigation and implementation of the SyncEvent Applet, which was the embryo of the Presentation and Synchronization Module.

The main result of this work, the Presentation and Synchronization Module (MAS), is introduced both from its architectural and implementation aspects. Finally, in the conclusion, the contributions of the work are discussed along with its limitations and related future work, which includes integrating the MAS with the remaining modules of the SMmD project. 
"Começar já é metade de toda ação."

Provérbio grego

Na última década houve um crescimento explosivo no uso de dados e aplicações multimídia. Hoje em dia, computadores e redes processam e transmitem muito mais que apenas texto e imagens estáticas. Mídias contínuas, como vídeo e áudio, juntamente com mídias discretas, como gráficos, se tornaram parte de aplicações integradas de computador [Buf94].

As novas aplicações que estão surgindo fazem crescer a cada dia a necessidade de distribuição de dados e de processamento. Entre essas novas aplicações estão os grandes sistemas hipermídia, que são inerentemente distribuídos e por isso requerem a adoção de padrões para representação e intercâmbio de dados multimídia [LV95].

Um dos fatores que contribuiu para a evolução dos sistemas hipermídia foi a expansão e a disseminação da rede mundial de computadores Internet. No entanto, existem ainda várias limitações à plena utilização de hiperdocumentos que incorporem dados multimídia remotos.

Entre os serviços oferecidos pela Internet, um dos que mais se destaca é a WWW (World Wide Web). A WWW utiliza a linguagem HTML (HyperText Markup Language) para realizar o intercâmbio de documentos através da rede. Um documento HTML nada mais é que um arquivo texto com códigos de marcação especiais e que pode ser visualizado pelo usuário através de um programa navegador, como o Netscape $e^{\mathrm{TM}}$, por exemplo.

A linguagem HTML se consolidou na WWW devido à sua simplicidade, tendo se tornado um padrão de facto. Qualquer pessoa com conhecimentos básicos em computação tem condições de produzir um documento HTML e disponibilizá-lo na WWW. No entanto, esta simplicidade impede que a linguagem HTML, na sua atual especificação, permita interações complexas com o usuário e represente objetos multimídia que possuam relações temporais. A fim de solucionar este problema, o World Wide Web Consortium (W3C) elaborou recentemente a recomendação 
SMIL [W3C98a] - Synchronized Multimedia Integration Language - que provê uma linguagem para especificação de sincronização de objetos multimídia no contexto da WWW.

No entanto, existem diversos tipos de aplicações multimídia distribuídas que não usam os serviços da WWW. Entre eles pode-se citar aplicações de vídeo sob demanda, jogos em rede e a TV interativa ou TV digital. Direcionado para estas aplicações, a International Standards Organisation (ISO) desenvolveu o padrão MHEG (acrônimo de Multimedia and Hypermedia information coding Expert Group), o qual tem sido definido desde o início com a preocupação de viabilizar a troca de objetos multimídia em tempo real e sob demanda e facilitar a interação com o usuário, sem direcionar as aplicações para um contexto específico, como é o caso do SMIL.

Com o surgimento do padrão MHEG, alguns grupos de pesquisadores têm trabalhado no sentido de modelar e implementar ambientes adequados à execução de aplicações multimídia. Neste contexto se insere o projeto $\mathrm{SMmD}^{1}$ [Tei94], do qual faz parte o trabalho relatado neste documento. O projeto SMmD utiliza o padrão MHEG-5 [ISO97] no desenvolvimento de uma estrutura de middleware (componentes de software do sistema situados entre sistemas operacionais genéricos e aplicações), chamada Ambiente SMmD, ou ASMmD [Tei98], oferecendo um conjunto de serviços para facilitar a construção de aplicações multimídia interativas.

Este documento aborda o desenvolvimento de um dos módulos do projeto $\mathrm{SMmD}$, chamado MAS, Módulo de Apresentação e Sincronização. O MAS é o módulo que serve de interface entre os usuários e aplicações e a máquina MHEG-5 do projeto SMmD, chamada JHEG (Java MHEG-5 Engine) [Abr97], sendo responsável pela apresentação e pela sincronização das mídias que compõem um objeto multimídia e também pelo controle das interações dos usuários com o Ambiente SMmD.

${ }^{1}$ O Projeto SMmD (Sistemas Multimídia Distribuídos: Suporte, Estrutura e Aplicações) é suportado pelo CNPq através do ProTeM-CC fase 2, sob número 680077/94-4. 
Esta dissertação possui, além deste capítulo introdutório, os seguintes capítulos:

- Capítulo 2 - Multimídia: Definições e Conceitos Básicos: define o termo multimídia, apresentando conceitos básicos relacionados a aplicações e sistemas multimídia.

- Capítulo 3 - Sincronização Multimídia: apresenta desde conceitos básicos, como a definição de sincronização intra e intermídia, até avançados, como os modelos de sincronização para apresentação multimídia. Este capítulo tem como finalidade embasar o leitor para o tema central deste trabalho, que é a implementação de sincronização multimídia no Módulo de Apresentação e Sincronização.

- Capítulo 4 - Padrões para Especificação de Apresentações Multimídia: descreve os padrões MHEG e HyTime e a recomendação SMIL. Maior ênfase é dada ao padrão MHEG, utilizado como base para o desenvolvimento do projeto SMmD.

- Capítulo 5 - O Projeto SMmD: apresenta o Ambiente SMmD, descrevendo seus principais módulos e o relacionamento entre eles.

- Capítulo 6 - O Applet SyncEvent: descreve o trabalho de pesquisa que antecedeu o desenvolvimento do MAS, enfatizando a implementação de um applet chamado SyncEvent. Este applet pode ser visto como uma versão simplificada do MAS. Sua implementação consistiu no embrião a partir do qual desenvolveu-se o Módulo de Apresentação e Sincronização.

- Capítulo 7 - O Módulo de Apresentação e Sincronizaçâo: detalha o funcionamento do MAS, apresentando sua arquitetura básica. Mostra também detalhes de sua implementação, sobretudo aqueles relacionados à implementação de sincronização multimídia, tema central do trabalho desenvolvido.

- Capítulo 8 - Conclusão: sintetiza as contribuições geradas pelo trabalho relatado neste documento e discute sua continuidade. 
Além disso, são apresentadas nos apêndices as seguintes complementações ao texto desta dissertação:

- Apêndice A: Notação textual de uma aplicação MHEG-5 chamada "Produção de Mídia Digital";

- Apêndice B: A API Java Media Framework Player, que estende a linguagem Java provendo facilidades para apresentação e sincronização multimídia. 
"O homem só aprende quando ensina."

Aristóteles

\subsection{Considerações Iniciais}

O trabalho relatado neste documento aborda a apresentação de objetos multimídia e a interação dos usuários com estes objetos. A fim de capacitar o leitor para o devido entendimento do trabalho realizado, é necessário apresentar uma série de conceitos relacionados ao tema multimídia.

Além da própria definição da palavra multimídia, este capítulo apresenta os vários tipos de mídia existentes e seus critérios de classificação. Além disso, são também abordadas as principais características de um sistema multimídia, dando ênfase aos requisitos necessários a este tipo de sistema, como o suporte a programação multithreading, por exemplo. Finalizando, o capítulo aborda os problemas relacionados ao intercâmbio de mídia contínua nos sistemas multimídia distribuídos, destacando a importância dos parâmetros de qualidade de serviço no gerenciamento desses problemas.

\subsection{Classificação de Mídias}

Existem várias formas de se definir a palavra multimídia. De acordo com as definições do latin, pode-se dividir a palavra em dois radicais:

- Multi: muitos; múltiplos.

- Mídia (medium): meio; substância ou matéria através da qual alguma coisa é transmitida; meio de comunicação de massa, como jornal, revista ou televisão (do American Heritage Dictionary, 1991). 
A descrição acima é derivada das formas comuns de interação humana, não sendo, portanto, muito exata, devendo ser adaptada ao processamento computacional. Em computação, mídia é normalmente descrita como sendo um meio de distribuição e apresentação de informação. Exemplos de mídia são texto, gráfico, voz, música, etc. Uma mídia pode ser classificada de acordo com diferentes critérios [SN95], entre eles:

- Percepção: Este critério envolve a forma na qual os humanos percebem a informação num ambiente computacional. Uma vez que as formas mais comuns de percepção são a visão e a audição, de acordo com este critério as mídias se dividem em mídias visíveis (texto, imagens e vídeo) e audíveis (música, barulho, voz);

- Representação: Aborda a forma na qual as mídias são representadas internamente pelos computadores. Nessa abordagem, os formatos de representação usados servem para classificar as mídias. A codificação ASCII, por exemplo, é usada para representar caracteres de um texto e o formato JPEG é usado para codificar uma imagem;

- Apresentação: Refere-se ao uso de ferramentas e dispositivos na entrada e saída de informações. Neste critério, o mais importante é definir através de qual mídia uma informação entra ou sai do computador. Assim, as mídias papel, tela (monitor de vídeo) e alto falantes são usados na saída-de informações, enquanto que o teclado, o mouse, a câmera e o microfone são usados na entrada de dados;

- Armazenamento: Refere-se aos dispositivos usados no armazenamento de informações. No entanto, estes dispositivos não se limitam apenas aos componentes de um computador. Assim, uma folha de papel pode ser considerada uma mídia de armazenamento. Entre as principais mídias de armazenamento estão o disco rígido e o CD-ROM;

- Transmissão: Aborda os meios de comunicação (mídias) que possibilitam a transmissão de dados contínuos. Estes meios seriam as redes de computadores, compostas basicamente de fios e cabos de transmissão, como o cabo coaxial e as fibras óticas, além, é claro, do ar meio de transmissão das comunicaçōes sem fio (wirelles communications); 
- Intercâmbio de informação: Envolve todas as mídias usadas na transmissão de dados, ou seja, todas as mídias de armazenamento e transmissão de informações. Esta classificação é usada porque o processo de transmissão de dados muitas vezes usa mídias de armazenamento temporário, que podem ser transportadas para fora de uma rede de computadores até o destinatário através da transmissão direta entre diversas redes, ou através do uso conjunto de mídias de armazenamento e transmissão, como ocorre no sistema de correio eletrônico.

\subsection{Representação Espacial de Mídias}

Uma característica importante inerente a uma mídia é sua representação espacial. Cada espaço de representação consiste de uma ou mais dimensões de representação. Assim, a tela de um computador possui duas dimensões, não sendo, portanto, adequada para a representação de holografia, pois esta requer uma dimensão a mais. O tempo pode ocorrer dentro de cada espaço de representação como uma dimensão adicional, dividindo as mídias em dois tipos:

- Mídias não dependentes de tempo (discretas): são mídias nas quais a informação consiste exclusivamente de uma sequiência de elementos individuais ou de um continuum sem o componente de tempo. Exemplos de mídias discretas são textos e gráficos. $\mathrm{O}$ processamento de mídias discretas deve acontecer o mais rápido possível. No entanto, este processamento não é crítico em relação ao tempo uma vez que a validade e a corretude dos dados não depende de condições temporais.

- Mídias dependentes de tempo: são mídias que têm seus valores modificados com o tempo. Neste tipo de mídia, a informação é expressa não somente por valores individuais, mas também pela ordem de ocorrência desses valores. Exemplos desse tipo de mídia são som e vídeo full-motion. O processamento dessas mídias é crítico em relação ao tempo porque a validade e a corretude dos dados depende de condições temporais.

As mídias dependentes de tempo são subdivididas em mídias contínuas e não contínuas. Áudio e vídeo são classificados como mídias contínuas porque são constituídos de elementos discretos (frames e samples) que ocorrem de forma periódica no tempo. Dessa forma, valores de representação que ocorrem de forma aperiódica, como comandos de controle em um 
sistema de tempo real, não são caracterizados como mídia contínua, mesmo sendo dependentes de tempo.

\subsection{Sistemas Multimídia}

Baseado na definição de multimídia fornecida pelo American Heritage Dicitonary, um sistema multimídia seria qualquer sistema que suportasse mais de um tipo de mídia. No entanto, esta caracterização baseada apenas em aspectos quantitativos é insuficiente para definir um sistema multimídia. Mais que quantidade, é importante avaliar a qualidade das mídias apresentadas por um sistema antes de dizer se este sistema é ou não multimídia [SN95]. Um sistema multimídia se distingue de outros sistemas através de quatro propriedades principais:

- Combinação de mídias: nem toda combinação arbitrária de mídias justifica o uso do termo multimídia. Este termo deve apenas ser usado quando se combinam mídias contínuas e discretas.

- Independência entre mídias: diferentes mídias devem ter um nível de independência satisfatório em relação umas às outras. Mídias como áudio e vídeo são, algumas vezes, coletadas de forma simultânea e mantidas numa mesma mídia de armazenamento. Um sistema não pode ser considerado multimídia somente por apresentar estas duas mídias, uma vez que entre elas existe um alto grau de dependência.

- Integração de mídias suportada por computador: um sistema multimídia deve ser capaz de combinar várias mídias de forma arbitrária. Para que isso seja possível, o sistema deve suportar relações de sincronização espacial, temporal e semântica. Assim, não basta que um sistema apresente várias mídias simultaneamente para que ele seja considerado multimídia, é necessário também que o sistema permita que estas mídias interajam entre si.

- Comunicação: um sistema multimídia deve ser capaz de se comunicar com outros sistemas. Como a maioria dos computadores atualmente estão interconectados, é interessante que o sistema suporte aplicações multimídia distribuídas, como, por exemplo, programas de vídeo conferência. O sistema multimídia deve permitir que uma informação possa ser não somente 
criada, processada, apresentada e armazenada, mas também distribuída através da rede. Sistemas com estas características são chamados sistemas multimídia distribuídos.

\subsection{Requisitos para um Sistema de Apresentação Multimídia}

A apresentação de umạ aplicação multimídia requer a execução simultânea, sequencial e independente de dados heterogêneos. O problema da apresentação multimídia se assemelha muito ao problema da execução de threads sequienciais e paralelas em computação concorrente [Buf94]. Muitas linguagens concorrentes, como CSP e Ada, suportam o conceito de multithreading. No entanto, a solução presente nas linguagens concorrentes não se adequa ao problema da apresentação multimídia, uma vez que estas linguagens estão direcionadas para a solução de problemas que necessitam de um alto throughput, como a solução paralela para a inversão de matrizes. Por outro lado, a apresentação multimídia se preocupa com a apresentação coerente de mídias heterogêneas ao usuário. Assim, existe um limite na velocidade de fornecimento dos dados acima da qual o usuário não consegue assimilar o conteúdo da apresentação. Para os sistemas computacionais comuns é sempre desejável produzir uma solução no menor tempo possível. Os sistemas multimídia, por outro lado, devem priorizar a apresentação, não a computação.

Um outro fator que diferencia os sistemas concorrentes dos sistemas multimídia é a forma de tratar os eventos dependentes de tempo. Nos sistemas concorrentes existe uma grande preocupação com a ordem dos eventos que ocorrem em paralelo. No entanto, não existe preocupação com a taxa de execução desses eventos (a performance da CPU não é considerada). Os dados multimídia dependentes de tempo, por outro lado, devem obedecer limitações de precedência e tempo de execução, ou seja, se um dado multimídia deve ser apresentado por 10 segundos, apresentá-lo por 9 ou por 11 segundos não é permitido.

Um esquema de apresentação multimídia deve capturar a precedência dos componentes e obedecer as limitações de tempo impostas pelas aplicações. Uma metodologia de especificação para apresentações multimídia deve incluir a representação da semântica de tempo real e concorrência e também prover formas de modelagem hierárquica. A natureza da apresentaçāo de dados multimídia também implica outros requerimentos, como a possibilidade de reverter uma 
apresentação, de permitir acesso aleatório a qualquer ponto da mesma, de especificar temporização de forma parcial ou incompleta, de permitir o compartilhamento de componentes sincronizados entre aplicações e de prover meios de armazenagem de informações de controle [Buf94].

\subsection{Qualidade de Serviço em Sistemas Multimídia Distribuídos}

A importância da informação multimídia e da comunicação cresce com o aumento de consumidores potenciais dessa informação que estão conectados a alguma rede. Espera-se para um futuro próximo que os sistemas multimídia sejam acessíveis em larga escala e possam prover funções de distribuição similares à rede mundial de telefones e à Internet. No entanto, a difusão dos sistemas multimídia distribuídos esbarra nos problemas envolvidos no intercâmbio de mídia contínua [Buf94].

O termo mídia contínua, como já foi dito, refere-se à dimensão temporal de mídias como áudio e vídeo, nas quais a informação se resume a uma sequiência de amostras, cada uma com uma posição específica no tempo. Os requisitos de tempo envolvidos são reforçados durante o processo de apresentação e captura, quando os dados são visualizados pelos usuários. Além disso, dados de mídia contínua possuem geralmente um volume considerável. Estes dois fatores devem ser considerados no projeto de sistemas multimídia, diferenciando estes sistemas dos convencionais, sobretudo nos aspectos de gerenciamento de processos, arquivos e rede.

A fim de atender aos requisitos existentes no intercâmbio de mídia contínua, o gerenciamento de recursos, função principal de um sistema operacional, deve atender a uma nova classe de serviços, na qual restrições de tempo e níveis de serviço negociáveis devem ser satisfeitos. Assim, para a maioria das aplicações de mídia contínua é possível estabelecer níveis de serviço flexíveis, que variam de acordo com a carga do sistema. A flexibilidade do nível de serviço é estabelecida através de um processo de negociação entre a aplicação e o gerenciador de recursos local. O termo qualidade de serviço ( $Q O S$ - Quality of Service) é usado para representar os requerimentos da aplicação a um dado recurso [Buf94]. 
Parâmetros típicos de qualidade de serviço são: resolução máxima e mínima, taxa de erros permitida, limites de atraso e jitter aceitáveis. Resolução máxima e mínima referem-se à qualidade em que são exibidos objetos visíveis, como texto, imagem e vídeo. Taxa de erros está ligada aos protocolos de transporte de streams de vídeo e áudio. O parâmetro atraso refere-se ao tempo gasto no processo de intercâmbio de um dado multimídia entre a fonte e o destino. Por fim, jitter refere-se à variação desse atraso. Assim, se cada frame de um vídeo demora exatamente $10 \mathrm{~ms}$ entre a fonte e o destino, o jitter é igual a zero (não há variação no atraso). No entanto, devido a oscilações na carga da rede, quase sempre ocorrem variações no atraso durante o processo de transporte de um stream. A fim de oferecer uma boa qualidade de serviço na apresentação de uma mídia contínua, como áudio ou vídeo, o sistema multimídia deve tentar manter o valor do jitter constante e o mais próximo de zero possível.

O paradigma para gerenciamento de recursos no contexto de mídia contínua é baseado no fato de que algumas aplicações requerem garantias determinísticas de serviço, enquanto outras requerem garantias probabilísticas, ou ainda, garantias mínimas de serviço. Garantias determinísticas e probabilísticas podem ser asseguradas desde que fatores como carga do sistema, espaço de buffer e escalonamento de processos possam ser monitorados e controlados. O que diferencia as duas formas de garantia citadas é que as probabilísticas são mais flexíveis, permitindo que o gerenciador de recursos admita um maior volume de tráfego, o que leva a uma melhor utilização do sistema. Aplicações que requerem garantias de performance mínimas podem ser atendidas na política do melhor esforço (best effort basis).

O gerenciador de recursos do sistema controla os níveis de serviço oferecidos. Assim, para uma dada classe de serviços, o gerenciador executa um teste de admissibilidade quando um recurso é solicitado. $O$ teste determina se uma tabela de serviços que atenda os requisitos dos clientes pode ser construída. Em caso afirmativo, a solicitação é atendida. Caso contrário, o gerenciador de recursos pode recomendar classes de serviço de mais baixo nível que possam estar disponíveis. $O$ gerenciador de recursos mantem uma função de escalonamento através da qual os clientes admitidos são atendidos. Durante o ciclo de serviços, o gerenciador monitora o uso que cada aplicação faz dos recursos de modo a evitar que uma sobrecarga inesperada, gerada por um cliente, não cause a deteriorização dos serviços prestados a outros clientes. 
A natureza temporal das amostras de áudio e vídeo digital requer que parâmetros de $Q o S$ como atraso e jitter variem o mínimo possível do ponto de geração ou recuperação até o ponto de apresentação. Este requerimento é conhecido como sincronização intramídia. Quando vários streams de mídia contínua são apresentados em paralelo, geralmente a partir de diferentes pontos de geração ou recuperação, problemas referentes a relacionamentos temporais acontecem. Faz-se necessário então, realizar um ajuste de temporização entre as mídias envolvidas. Este ajuste é conhecido como sincronização intermídia. Os aspectos envolvidos na sincronização de mídias inter-relacionadas serão discutidos no próximo capítulo.

\subsection{Considerações Finais}

Neste capítulo foram introduzidos conceitos básicos que serão de grande utilidade para o entendimento dos assuntos apresentados no restante deste documento. Vários critérios de classificação de mídias foram apresentados, dos quais vale relembrar aquele que classifica uma mídia de acordo com as relações temporais entre seus componentes, identificando as mídias que são dependentes de tempo e as que não são. A importância dessa classificação está no fato de que as dependências temporais envolvendo mídias são um dos principais assuntos deste documento. A especificação dessas dependências recebe o nome de sincronização multimídia, assunto do próximo capítulo.

Além dos critérios de classificação de mídias, dois outros assuntos relevantes foram abordados neste capítulo. O primeiro refere-se aos sistemas multimídia e aos requisitos que tais sistemas devem possuir a fim de apresentar corretamente composições multimídia. O segundo refere-se aos problemas relacionados ao intercâmbio multimídia em sistemas distribuídos, abordando o uso de parâmetros de qualidade de serviço no sentido de estabelecer limites máximos para o atraso e o jitter no transporte de mídias contínuas. 
"Temos UMA boca e DOIS ouvidos, mas jamais nos comportamos proporcionalmente."

Provérbio chinês

\subsection{Considerações Iniciais}

A palavra sincronização refere-se a tempo, e sincronização em sistemas multimídia refere-se às relações temporais entre os objetos de mídia do sistema. Estas relações. envolvem objetos de mídia dependentes de tempo (mídias contínuas) e objetos de mídia não dependentes de tempo (mídias discretas). Um exemplo de sincronização de mídias contínuas é a sincronização entre a informação visual e acústica na televisão. Nos sistemas multimídia, uma sincronização semelhante deve ser provida para a apresentação de áudio e vídeo. Um exemplo de relações temporais entre mídias dependentes e não dependentes de tempo é o slide show, onde a apresentação de slides (mídia discreta) deve ser sincronizada com um áudio (mídia contínua) que comenta cada slide.

A sincronização de mídias é realizada por vários componentes de um sistema multimídia, como o sistema operacional, o sistema de comunicação, os gerenciadores de bancos de dados e as aplicações. Dessa forma, a sincronização deve ser analisada em vários níveis em um sistema multimídia [SN95].

O sistema operacional e as camadas básicas de comunicação manipulam streams de mídia com o objetivo de evitar a ocorrência de jitter na apresentação das unidades de cada stream. Imediatamente acima do sistema operacional existe uma camada que dá suporte em tempo de execução para a sincronização de múltiplos streams de mídia. O objetivo desta camada é manter as relações temporais entre vários streams que participam de uma mesma apresentação. Em seguida, existe a camada que dá suporte em tempo real à sincronização de mídias dependentes e não dependentes de tempo, além de também manipular a interação dos usuários [MES93]. Esta 
camada será abordada com mais profundidade, pois é nela que se insere o padrão MHEG assunto abordado no próximo capítulo.

Este capítulo está organizado da seguinte forma: a Seção 3.2 introduz os conceitos básicos sobre sincronização multimídia; a Seção 3.3 aborda problemas relacionados à apresentação síncrona de objetos de mídia inter-relacionados; a Seção 3.4 comenta modelos de referência para apresentação multimídia, dando maior ênfase ao modelo de camadas proposto por Meyer, Effelsberg \& Steinmetz [MES93]; a Seção 3.5 trata dos métodos de especificação de sincronização multimídia; a Seção 3.6 aborda problemas de sincronização em ambientes distribuídos; a Seção 3.7 apresenta os parâmetros de qualidade de serviço $(Q o S)$ relacionados à sincronização multimídia; e, finalmente, a Seção 3.8 faz algumas considerações a respeito da importância dos assuntos abordados neste capítulo.

\subsection{Noções Básicas de Sincronização}

O processamento de mídias integradas é uma das principais características dos sistemas multimídia. A principal razão da necessidade de integração de mídias é a dependência inerente entre a informação codificada em diferentes objetos de mídia. Estas dependências devem ser mantidas durante os processos de armazenamento, manipulação, comunicação, captura, e sobretudo, apresentação desses objetos. A tarefa de manter as interdependências temporais entre objetos de mídia recebe o nome de sincronização multimídia [SN95].

Nesta seção são apresentados os conceitos básicos de sincronização, abordando as relações de sincronização existentes, as formas de especificação de dependências temporais entre objetos de mídia, as unidades lógicas de dados (ULDs - usadas na sincronização fina), e também a sincronização intra e interobjeto.

\subsubsection{Relações de Sincronização}

A palavra sincronização está diretamente ligada ao fator tempo. No entanto, a palavra sincronização refere-se não somente às relações temporais, mas também às relações espaciais e de conteúdo dos objetos de mídia [SN95]. 
As relações de conteúdo definem a dependência de objetos de mídia a algum dado. Por exemplo, o conteúdo de uma planilha pode estar associado a um gráfico que representa seus dados. Dessa forma, qualquer mudança nos dados da planilha implica uma mudança no gráfico exibido. Documentos com esta característica são chamados documentos multimf́dia integrados. A sincronização multimídia é muito importante neste tipo de documentos.

As relações espaciais, também conhecidas como relações de layout, servem para definir um espaço de apresentação de objetos de mídia em um dispositivo de saída em um certo momento do tempo. Assim, se o dispositivo de saída tem duas dimensões (monitor ou folha de papel), as relações de layout especificam a área bidimensional a ser usada em um dado momento da apresentação.

As relações temporais, por sua vez, definem dependências de tempo entre diferentes objetos de mídia. Estas relações devem ser consideradas em qualquer apresentação que envolva objetos de mídia dependentes de tempo. Apesar da existência das relações espaciais e de conteúdo, a sincronização em sistemas multimf́dia refere-se sobretudo aos aspectos temporais do relacionamento entre objetos de mídia, tendo as relações espaciais e de conteúdo normalmente pouca importância dentro desse contexto.

\subsubsection{Sincronização Intra e Interobjeto}

Existem relações temporais entre as unidades de um objeto de mídia dependente de tempo e relações temporais entre diferentes objetos de mídia. As primeiras definem a sincronização que deve existir entre as componentes de um mesmo objeto, ou seja, sincronização intra-objeto. As últimas, definem a sincronização existente entre objetos de mídia distintos, chamada sincronização interobjeto [SN95].

Um exemplo de sincronização intra-objeto é a relação temporal existente entre os frames de uma sequiência de vídeo. Para um vídeo com taxa de 25 frames por segundo, cada frame deve ser exibido por $40 \mathrm{~ms}$. A Figura 3.1 mostra este exemplo para uma seqüência de vídeo que apresenta uma bola em movimento vertical. 


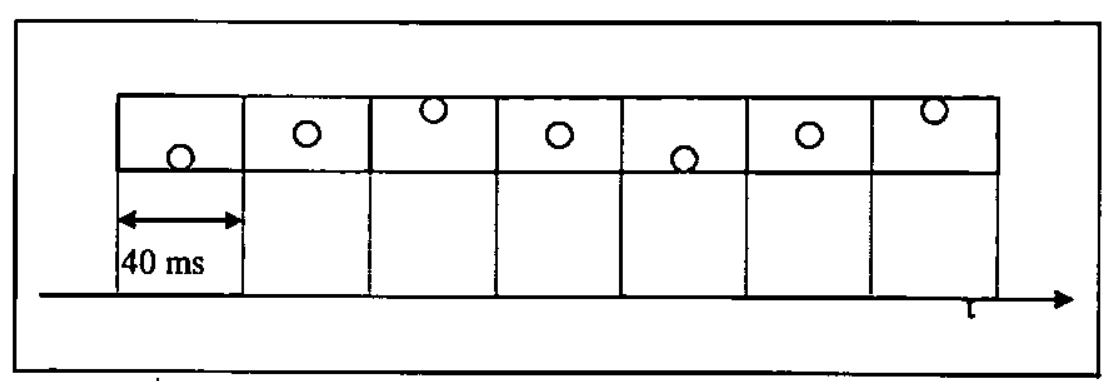

Figura 3.1 - Sincronização intra-objeto entre frames de uma seqüência de video [SN95]

A sincronização interobjeto deve ocorrer em toda e qualquer apresentação que envolva dois ou mais objetos de mídia, onde pelo menos um deles é um objeto de mídia contínua. A Figura 3.2 mostra um exemplo de sincronização interobjeto no qual objetos de mídia como áudio, vídeo, animação e imagens estáticas são apresentados. Estes objetos devem ser apresentados de forma ordenada no tempo, mantendo as dependências temporais especificadas.

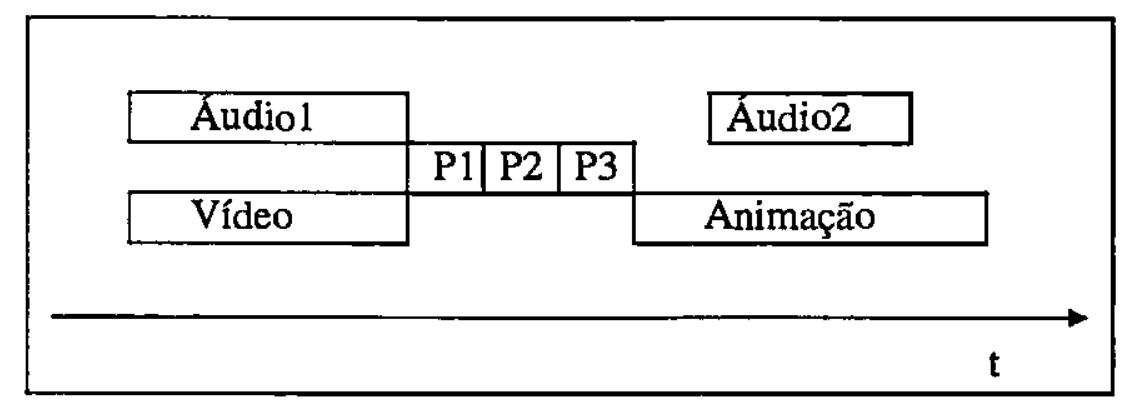

Figura 3.2 - Exemplo de sincronizaçāo interobjeto [SN95]

\subsubsection{Unidades Lógicas de Dados}

Objetos de mídia dependentes de tempo geralmente são constituídos de uma sequiência de unidades de informação. Estas unidades de informação são chamadas unidades lógicas de dados (ULDs) [SN95]. 
$\mathrm{Na}$ majoria das vezes existem vários níveis de granularidade de ULDs em um objeto. Um exemplo disso é, por exemplo, um objeto de vídeo não comprimido dividido em cenas e frames. Cada frame pode ser particionado em áreas de $16 \times 16$ pixels. Cada pixel é dividido em luminance values e crominance values. Todas estas unidades são candidatas a se tornar ULD do objeto.

Os níveis de granularidade implicam uma decomposição hierárquica dos objetos de mídia. Existem dois tipos de hierarquia:

- Hierarquia de conteúdo: gerada pelo conteúdo do objeto de mídia. Assim, uma sinfonia é composta por movimentos, que por sua vez são compostos por notas musicais;

- Hierarquia de codificação: baseada na forma em que os dados estão codificados. Nesta hierarquia, um movimento de uma sinfonia pode ser representado por um objeto de mídia. Cada objeto que representa um movimento pode ser dividido em blocos de amostras. As amostras seriam, então, o nível mais baixo na hierarquia de codificação.

As ULDs são ainda classificadas em abertas e fechadas. ULDs fechadas são aquelas que têm uma duração pré-definida. Exemplos de ULDs fechadas são as ULDs que compõem objetos de mídia contínua armazenados, como áudio e vídeo. ULDs abertas, por sua vez, são aquelas que não possuem duração pré-definida. As ULDs abertas ocorrem, por exemplo, nos objetos de mídia que envolvem interação do usuário.

\section{Classificação das Unidades Lógicas de Dados}

Para vídeo digital, geralmente os frames são selecionados como ULDs. Por exemplo, para um vídeo com 30 frames por segundo, cada ULD tem a duração de 1/30 segundos.

Em alguns casos, a ULD é muito pequena para ser manipulada. É o que acontece com os streams de áudio, nos quais a duração de cada unidade física tem uma dimensão muito reduzida, o que faz com que cada ULD seja formada por um bloco de amostras (geralmente composto de 512 amostras). 
A importância das ULDs pode ser melhor observada quando se deseja realizar sincronização labial (lip synchronization). A Figura 3.3 mostra um exemplo de sincronização labial entre um objeto de áudio e um objeto de vídeo. Através do uso de ULDs, é possível especificar que o frame $n$ do objeto de vídeo deve ser apresentado simultaneamente à amostra $m$ do objeto de áudio.

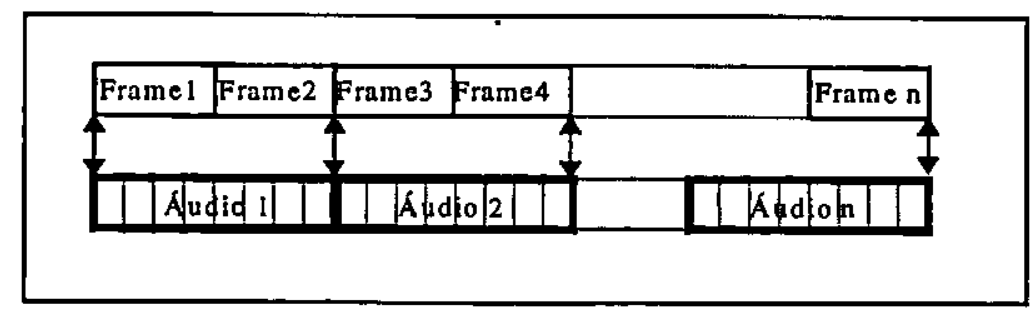

Figura 3.3 - Visão das ULDs de uma sincronização labial [SN95]

\subsubsection{Especificação de Dependências Temporais}

O processo de autoria de apresentações multimídia consiste basicamente em se especificar relações, a maioria dependentes de tempo, entre os componentes da aplicação. O sistema multimídia, por sua vez, deve interpretar estas especificações e prover a apresentação adequada. Interpretar especificações significa processar cada item da apresentação de acordo com os parâmetros de sincronização estabelecidos no processo de autoria. Portanto, os modelos de tempo são importantes tanto no processo de autoria (especificação de relações temporais) quanto no processo de apresentação (identificação de relações temporais). Existem diversos tipos de dependências temporais, que variam de acordo com a forma em que os dados são capturados ou apresentados [Buf94]. A Tabela 3.1 mostra algumas definiçōes de dependências temporais.

Dependências de tempo presentes no momento da captura dos dados são chamadas naturais ou implícitas. Um exemplo de dependência natural é aquela existente entre objetos de vídeo e áudio capturados simultaneamente. Estes streams de dados são descritos como contínuos, uma vez que os elementos de dados gravados são exibidos de forma contígua no tempo. Por outro lado, dados também podem ser capturados sem nenhuma ordem específica (por exemplo, um conjunto de 
fotografias). Sem uma dependência de tempo, estes dados são ditos estáticos. Dados estáticos podem ter relações temporais sintéticas, ou seja, relações temporais criadas artificialmente.

Tabela 3.1- Definiçōes de dependências temporais [Buf94]

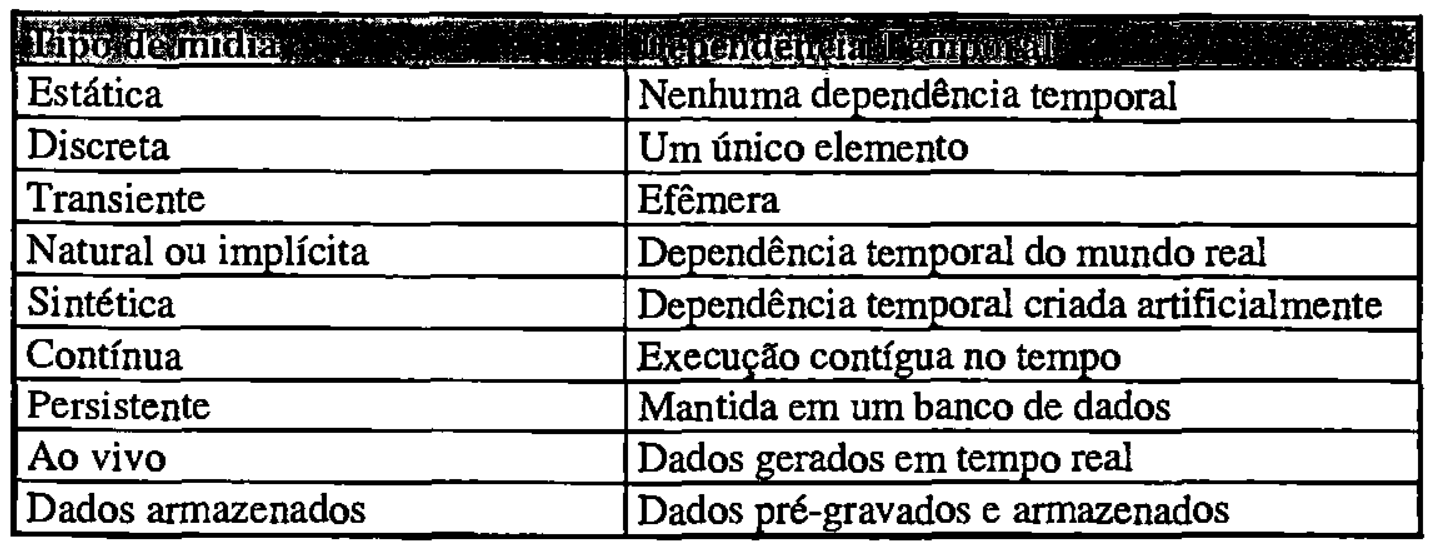

A combinação de dependências temporais naturais e sintéticas descrevem os requerimentos temporais de qualquer apresentação multimídia pré-orquestrada [Buf94]. No momento da apresentação, os dados podem manter suas dependências temporais naturais ou podem ser "forçados" a participar de relacionamentos temporais sintéticos. Um relacionamento sintético possui uma dependência temporal fabricada de acordo com as necessidades da aplicação. Por exemplo, um filme (longa metragem) consiste de uma seqüência de cenas gravadas. Estas cenas são gravadas naturalmente, mas arranjadas de forma artificial durante o processo de edição do filme. De forma similar, uma animação é uma ordenação sintética de dados estáticos. Uma fonte de dados "ao vivo" é uma fonte gerada dinamicamente e em tempo real, contrastando com as fontes de dados pré-armazenados. As relações sintéticas são válidas apenas para dados armazenados, uma vez que não é possível reordenar ou conhecer os valores futuros de uma fonte gerada "ao vivo".

Dados multimídia podem ainda ser classificados de acordo com a duração de sua existência e de sua apresentação. Um objeto persistente é aquele que existe durante toda a execução da aplicação. Um objeto não persistente é criado dinamicamente e descartado quando obsoleto. Com relação à apresentação, um objeto transiente é definido como um objeto que é apresentado por uma curta duração de tempo. 
É importante observar que as definições de dependências temporais não são mutuamente exclusivas, ou seja, um mesmo objeto de mídia pode se enquadrar em duas ou mais dessas definições.

\subsection{Requisitos de Apresentação}

A fim de apresentar corretamente dados multimídia na interface do usuário, a sincronização é fundamental. Não é possível, no entanto, mensurar objetivamente a sincronização a partir do ponto de vista subjetivo da percepção humana, uma vez que esta varia de pessoa para pessoa. Portanto, apenas critérios heurísticos podem determinar se a apresentação de um stream está sincronizada ou não [SN95]. Nesta seção são apresentados experimentos extensivos que abordam a percepção humana da sincronização em diferentes mídias.

Os requisitos de apresentação incluem, para sincronização intra-objeto, a precisão relacionada aos atrasos na apresentação das ULDs de um stream qualquer e, para sincronização interobjeto, a precisão na apresentação paralela de objetos de mídia.

Um outro requisito de apresentação que deve ser considerado é o problema gerado pelo bloqueio de um stream que está sendo apresentado de forma síncrona com outros objetos de mídia. Este problema é conhecido como gap problem, e será abordado a seguir.

\subsubsection{Gap Problem}

Uma apresentação multimídia pode ser composta por um ou mais streams de dados que, na maioria das vezes, são capturados e armazenados separadamente em servidores de mídia contínua. A aplicação encarregada de mostrar esta apresentação deve, então, solicitar aos servidores de mídia os streams requeridos e sincronizá-los, apresentando-os em paralelo. Mas, o que acontece se um dos streams for interrompido, mesmo que temporariamente, antes do seu término normal? Nesse caso, a aplicação deve prover artifícios para controlar o problema, minimizando ao máximo o efeito causado na apresentação como um todo. O problema causado pela interrupção de um stream é chamado gap problem. 
Duas soluções são propostas para o gap problem [SN95]. A primeira, conhecida como bloqueio restritivo, consiste em se repetir a última ou as últimas amostras do stream recebidas antes de sua interrupção, ou ainda prover um stream alternativo que possa ser usado caso ocorra um gap. A outra forma baseia-se na realização de uma reamostragem de um ou mais streams com o propósito de restabelecer a sincronização perdida devido a um gap. A solução mais indicada para o problema varia de acordo com a duração do gap, uma vez que o mesmo pode durar desde alguns milisegundos até vários minutos. Cabe à aplicação (e não ao sistema multimídia) optar pela melhor solução. As soluções para este problema são detalhadamente abordadas a seguir.

\section{Método do Bloqueio Restritivo}

O método do bloqueio restritivo, como já foi dito, consiste em se repetir a última ou as últimas amostras de um stream interrompido. Assim, para um stream de vídeo, o último frame recebido é mostrado como uma imagem estática. Uma outra forma de solução do problema através de bloqueio restritivo consiste na especificação de uma apresentação alternativa, que é apresentada toda vez que um gap excede um determinado limite de tempo. A Figura 3.4 mostra esta solução. Nela pode-se observar que, quando ocorre um gap no stream de áudio, uma apresentação alternativa é acionada, cobrindo a falta do stream interrompido.



Figura 3.4 - Solução para o Gap Problem através do Método de Bloqueio Restritivo [SN95] 


\section{Método da Reamostragem de um Stream}

O problema gerado por um gap em um stream pode ser também solucionado através da reamostragem desse stream, desde que o gap tenha uma duração curta (de no máximo alguns segundos). A solução consiste em aumentar ou diminuir a velocidade em que o stream é apresentado, até que se alcance a sincronização desejada. Este tipo de solução é conhecida como reamostragem on-line. A reamostragem de um stream pode também ser usada para sincronizar mídias capturadas a partir de dispositivos diferentes, que podem, e muitas vezes têm, uma precisão insuficiente em seus cristais de clock. Um exemplo disso ocorre quando se captura um concerto musical com dispositivos de áudio e vídeo diferentes. A duração da apresentação dessas duas mídias de acordo com a taxa de amostragem das sequências de áudio e vídeo armazenadas

pode variar. É necessário então, fazer a reamostragem de um dos streams de forma a se obter a sincronização requerida. Este processo recebe o nome de reamostragem off-line, uma vez que os streams se encontram armazenados (não são gerados ou recebidos via rede em tempo real).

A percepção humana da reamostragem de streams depende muito do tipo de mídia utilizado. No caso de vídeo, a reamostragem através da inserção ou remoção de frames pode ser feita sem muitos problemas - é o que acontece nas conversões NTSC/PAL. Por outro lado, a reamostragem de streams de áudio é bem mais complexa. Um usuário certamente se sentirá desconfortável ao ouvir um trecho de áudio que possua blocos repetidos ou removidos. Além disso, mudanças na taxa de playback podem ser facilmente percebidas pelo usuário, uma vez que essa mudança causa uma variação instantânea na freqüência do áudio. Todos estes problemas inviabilizam a reamostragem on-line de streams de áudio [SN95].

\subsubsection{Sincronização Labial e Sincronização de Ponteiros}

A sincronização labial (lip synchronization) e a sincronização de ponteiros referem-se aos relacionamentos temporais entre streams de áudio e vídeo que possuem um alto grau de acoplamento, isto é, são fortemente inter-relacionados. 


\section{Sincronização Labial}

A sincronização labial deve ser observada no caso de apresentações que envolvam uma pessoa falando. Se o usuário percebe uma falta de sincronismo entre os movimentos dos lábios do interlocutor e as palavras que estão sendo olvidas, então diz-se que os streams não estão em sincronismo. A diferença de tempo entre ULDs de áudio e vídeo relacionados é chamada skew (variação). Quando skew $=0$, a apresentação está em sincronismo, quando skew <0, o áudio está atrasado em relação ao vídeo e, finalmente, quando $s k e w>0$, o vídeo está atrasado em relação ao áudio.

Experimentos realizados no IBM European Networking Center [SE93] mostram que pequenas variações na sincronização dos streams (para mais ou para menos) são praticamente imperceptíveis à maioria dos usuários. Dessa forma, variaçōes de $-80 \mathrm{~ms}$ até $+80 \mathrm{~ms}$ não são percebidas pela maioria das pessoas, portanto, variações dentro desse intervalo são consideradas aceitáveis. É importante destacar, no entanto, que a percepção humana da sincronização labial é extremamente subjetiva. $O$ experimento mostra casos de pessoas que não percebiam a falta de sincronismo entre áudio e vídeo mesmo com variações inferiores a -160 ms e superiores a +160 ms.

\section{Sincronização de Ponteiros}

Com o advento do Trabalho Cooperativo Suportado por Computador - CSCW (ComputerSupported Cooperative Work) - câmeras e microfones passaram a ser incorporadas às estações de trabalho dos usuários, permitindo que discussões de trabalho sejam feitas on-line através do computador. Neste tipo de trabalho, um mesmo objeto pode ser manipulado por vários usuários remotos. Cada usuário deve ter um feedback das suas ações e perceber as ações dos outros participantes em tempo real.

Um problema inerente ao ambiente CSCW é a sincronização entre a voz de um usuário e suas ações, realizadas com o mouse. Assim, se um usuário aponta um determinado objeto e fala algo sobre ele, os demais usuários devem ver o ponteiro se posicionar sobre o referido objeto no 
mesmo instante em que ouvem a referência àquele objeto. O problema da sincronização.de voz $\mathrm{e}$ ponteiro não é tão drástico quanto o problema da sincronização labial, e variaçð̃es de até $500 \mathrm{~ms}$ (para mais e para menos) não são perceptíveis para a maioria dos usuários.

\subsection{Modelos de Referência para Sincronização Multimídia}

Os modelos de referência para sincronização multimídia são necessários para [SN95]:

- entender os diversos requisitos relacionados à sincronização multimídia;

- identificar e estruturar mecanismos de run-time que suportem a execução de sincronização;

- identificar a interface existente entre esses mecanismos de run-time;

- comparar soluções para o problema de sincronização multimídia.

Algumas classificações foram propostas na tentativa de se estabelecer um modelo de referência. Little \& Ghafoor [LG90], por exemplo, propuseram a classificação de objetos multimídia de acordo com a sincronização intermídia e intramídia utilizada. Ehley, Furth \& Ilyas [EFI94] propuseram uma classificação baseada no controle remoto ou local da sincronização de objetos de mídia. Por fim, Meyer, Effelsberg \& Steinmetz [MES93] propuseram uma classificação baseada em camadas de sincronização.

A classificação de Meyer, Effelsberg \& Steinmetz possui quatro camadas, como mostra a Figura 3.5. A primeira, chamada camada de mídia, é responsável pela sincronização intrastream entre mídias dependentes de tempo. A segunda, conhecida como camada de stream, realiza a sincronização entre streams de mídia (sincronização interstream). A terceira, chamada camada de objeto, é responsável pela apresentação de mídias dependentes e não dependentes de tempo. Finalmente, a quarta camada, conhecida como camada de especificação, permite a autoria de aplicações multimídia [MES93]. Cada uma das quatro camadas do modelo será detalhadamente abordada a seguir. 


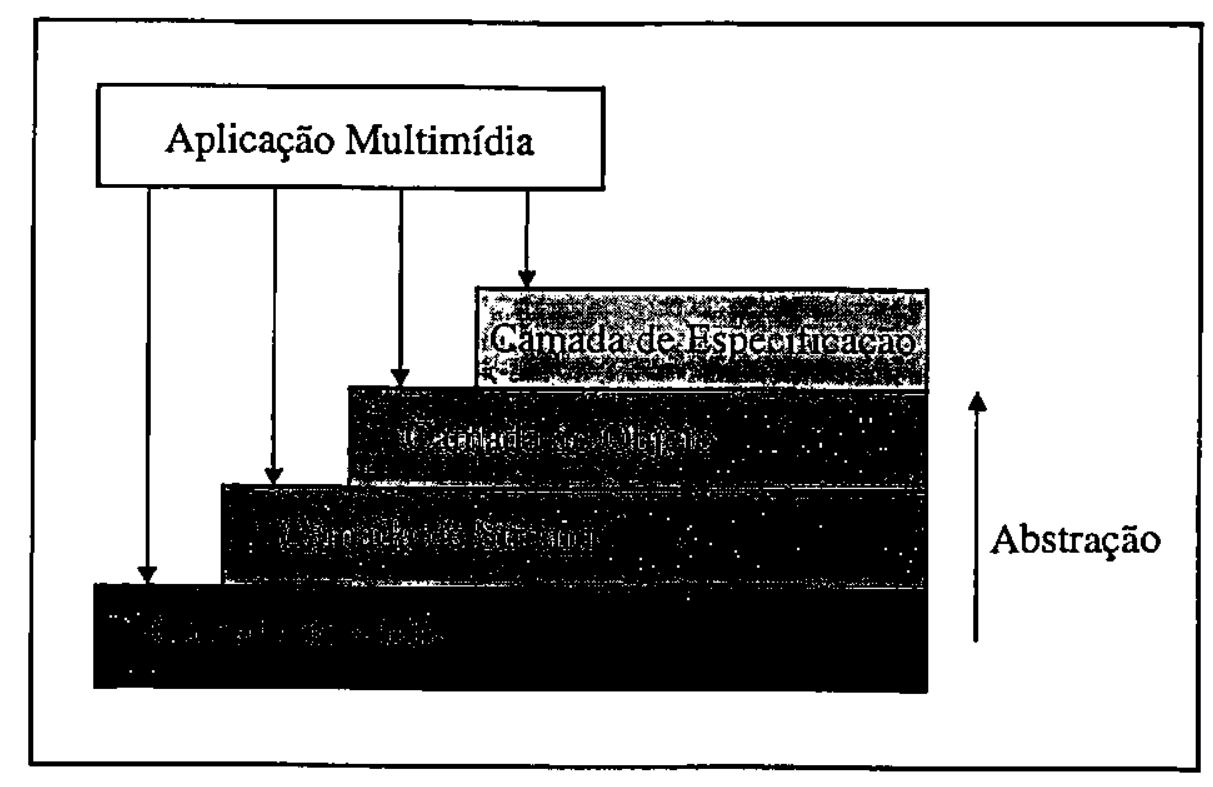

Figura 3.5 - Modelo de referência de quatro camadas [MES93]

\subsubsection{A Camada de Mídia}

Na camada de mídia, uma aplicação opera sobre um único stream de mídia contínua, o qual é tratado como uma sequiência de ULDs. A abstração oferecida nessa camada consiste de uma interface independente de dispositivo com operações como:

read(deviceHandle, ULD) ou write(deviceHanle, ULD).

Usando esta camada, a própria aplicação é responsável pela sincronização intrastream. Neste caso, a sincronização é feita através do uso de mecanismos de controle de fluxo entre um dispositivo produtor e um dispositivo consumidor de streams. No caso especial de sincronização labial, a sincronização interstream pode ser provida facilmente através do entrelaçamento (interleaving) de frames simultâneos de áudio e vídeo dentro da mesma ULD. Assim, as implementações da camada de mídia podem ser classificadas em implementações simples e implementaçőes que provêem acesso a streams de mídia entrelaçados. 


\subsubsection{A Camada de Stream}

A camada de stream opera sobre streams de mídia contínua provendo sincronização intrastream, e também sobre grupos de streams de mídia provendo sincronização interstream quando a apresentação paralela de streams é necessária. A abstração oferecida nesta camada é a noção de stream com parâmetros de temporização relacionados à qualidade de serviço (QoS) para sincronização intra e interstream.

Mídias contínuas são vistas pela camada de stream como um fluxo de dados que possui condições temporais implícitas; ULDs individuais não são visíveis. Os streams são executados em um ambiente de tempo real, onde todo processamento é regido por especificações temporais bem definidas. Por outro lado, aplicações que usam os serviços da camada de stream são executadas em um ambiente chamado NRTE (Non Real-Time Environment), no qual o processamento de eventos é controlado pela política de escalonamento do sistema operacional.

Alguns exemplos de operações invocadas a partir do NRTE por aplicações que desejam manipular streams e grupos de streams são:

- $\operatorname{start}($ stream);

- $\operatorname{stop}($ stream);

- create_group(list_of_streams);

- $\operatorname{start(group)e}$

- $\operatorname{stop}($ group).

A interação de streams com mídias não dependentes de tempo e com o usuário é feita através da junção de eventos aos streams de mídia contínua. A operação abaixo, por exemplo, realiza uma junção deste tipo:

setcuepoint(stream/group, at, event). 
Assim, quando um stream em processo de playback encontra um evento de interação, este evento é enviado à aplicação, que, nesta camada, é responsável pelo processamento de objetos de mídia não dependentes de tempo e por interações com o usuário.

As implementações da camada de stream podem ser classificadas de acordo com o suporte dado à distribuição (fim-a-fim ou local), de acordo com os tipos de garantia de serviço oferecidos (melhor esforço ou determinístico) e de acordo com o tipo de stream suportado (analógico e/ou digital) [SN95].

Uma aplicação usando a camada de stream é responsável por iniciar, finalizar e agrupar streams, e, além disso, deve definir os parâmetros de $Q o S$ que serão utilizados pela camada de stream. A aplicação também é responsável pela sincronização de streams com objetos de mídia não dependentes de tempo.

\subsubsection{A Camada de Objeto}

A camada de objeto opera sobre todos os tipos de mídia, oferecendo às aplicaçōes a abstração de uma apresentação sincronizada. A camada de objeto recebe uma especificação de sincronização multimídia como entrada e gera uma apresentação sincronizada como saída. As funçöes localizadas na camada de objeto são responsáveis pela execução de roteiros completos de apresentação que incluem a apresentação de objetos de mídia não contínua e chamadas à camada de stream. Além disso, a camada de objeto é responsável por iniciar a preparação de ações que são necessárias a fim de se obter uma apresentação corretamente sincronizada. A camada de objeto não manipula a sincronização intrastream e interstream. Para este propósito ela usa os serviços da camada de stream.

Um exemplo de implementação da camada de objeto é a especificação MHEG, assunto do próximo capítulo. Uma possível implementação dessa camada pode ser feita através de um sistema run-time MHEG, conhecido como MHEG engine. A função do MHEG engine é avaliar o status de objetos e realizar operações (ações) como prepare, run, stop e destroy sobre estes objetos. No caso de objetos de mídia dependentes de tempo, a operação run pode ser mapeada 
para a inicialização de um stream de mídia na camada de stream. No caso de um objeto de mídia não dependente de tempo, a operação run faz com que o objeto seja diretamente apresentado.

A fim de apresentar corretamente um objeto, o MHEG engine necessita de um tempo para a preparação do mesmo (operação prepare). Isto ocorre porque, no caso de objetos de mídia contínua, o engine deve contactar a camada de stream para que ela apresente o referido objeto. No caso de objetos de mídia discretos, a preparação é necessária a fim de que os dispositivos de saída sejam preparados para a apresentação do objeto.

Neste contexto, a tarefa de uma aplicação que deseja utilizar a camada de objeto é fornecer uma especificação de sincronização adequada.

\subsubsection{A Camada de Especificação}

Esta camada é uma camada aberta, que não oferece nenhuma interface específica. Ela inclui aplicações e ferramentas que permitem a criação de especificações de sincronização. Exemplos dessas aplicações e ferramentas são editores de sincronização, editores de documentos multimídia, sistemas de autoria e ferramentas de conversão, capazes de converter especificações para um formato aceitável pela camada de objeto, como, por exemplo, um formatador de documentos multimídia que produz especificações MHEG.

Uma outra função da camada de especificação é mapear os requerimentos de $Q o S$ do nível de usuário para os serviços oferecidos pela interface da camada de objeto.

Os métodos de especificação de sincronização podem ser classificados em quatro categorias principais [SN95]:

- Especificações baseadas em intervalos, que permitem a especificação de relações temporais entre intervalos de tempo das apresentações de objetos de mídia;

- Especificações baseadas em eixos, que relacionam eventos de apresentação com eixos que são compartilhados pelos objetos da apresentação; 
- Especificações baseadas em controle de fluxo, nas quais o fluxo da apresentação é sincronizado em pontos de sincronização pré-estabelecidos;

- Especificações baseadas em eventos, nas quais a ocorrência de eventos durante a apresentação das mídias dispara a execução de ações.

Cada um desses métodos de especificação de sincronização é detalhadamente descrito a seguir.

\subsection{Métodos de Especificação de Sincronização Multimídia}

Para a especificação de sincronização de múltiplos objetos de mídia, incluindo interação do usuário, métodos sofisticados de especificação devem ser usados. Nesta seção, os principais métodos de especificação de sincronização multimídia são abordados.

\subsubsection{Especificações Baseadas em Intervalos}

Através do conceito de instante e intervalo é possível estabelecer um modelo de tempo conceitual aplicável ao problema de sincronização multimídia [Buf94]. Em primeiro lugar, é importante definir o que é um instante e o que é um intervalo.

Um instante é um momento de comprimento zero no tempo, como por exemplo 4:00 da tarde. Por outro lado, um intervalo de tempo é definido como sendo o comprimento (duração) entre dois instantes. Assim, dados dois instantes $a$ e $b$, sendo $b>a$, o comprimento do intervalo é dado por $b$ - $a$, ou seja, a diferença entre os instantes final e inicial. Uma outra forma de especificar intervalos usa comparações ao invés de pontos. Nesta forma de especificação, um intervalo é definido em função de outro ou outros intervalos, o que possibilita a geração de relações temporais.

Segundo Allen [All83], existem treze formas nas quais dois intervalos podem se relacionar no tempo. Estas relações estão representadas graficamente na Figura 3.6. É importante observar que as treze relações são representadas por sete casos, uma vez que seis deles são inversos. Por exemplo, before é a relação inversa de after, ou de forma equivalente, after $^{-1}$ é a relação inversa de after; além disso, a equals b é o mesmo que b equals a. 


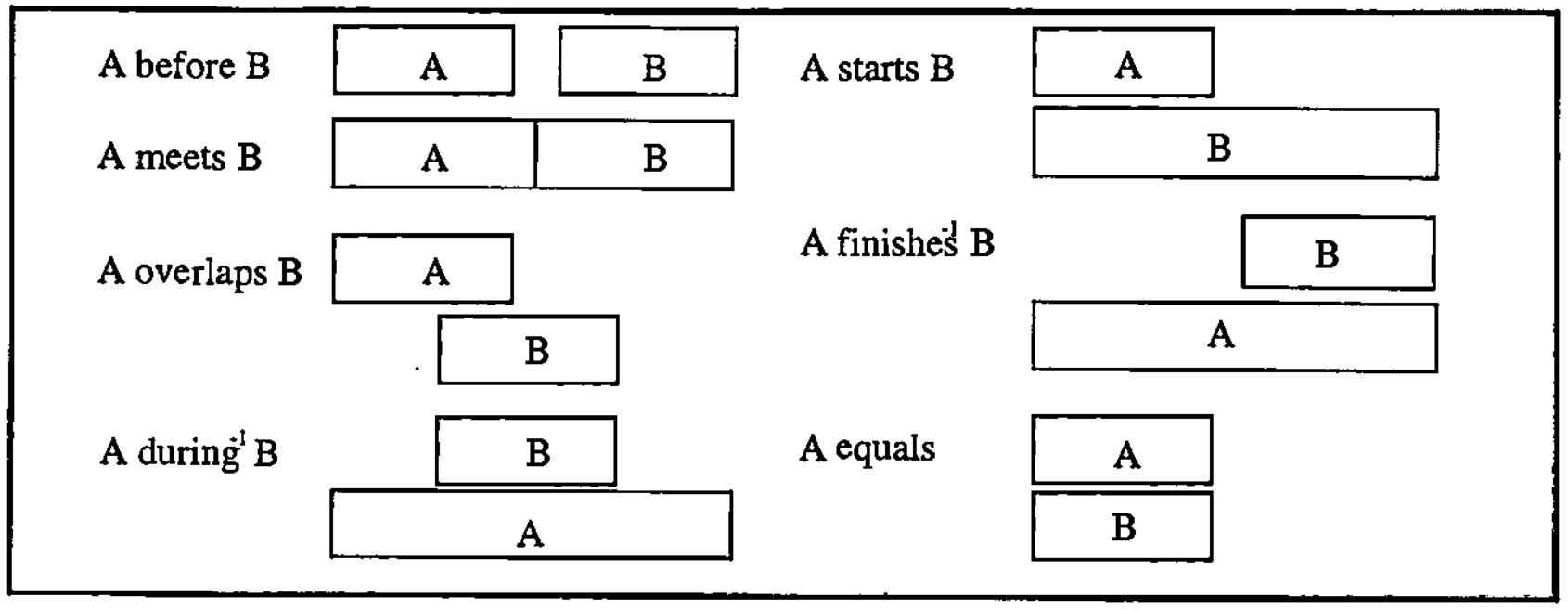

Figura 3.6 - Relações temporais binárias [All83]

É possível estender as 13 relações temporais binárias básicas através do modelo avançado de sincronização baseado em intervalos, proposto por Wahl e Rothermel [WR94]. Neste modelo, 29 relações relevantes à apresentação multimídia são obtidas a partir de disjunções das relações básicas entre intervalos mostradas na Figura 3.6. A fím de simplificar a especificação de sincronização, dez operadores foram definidos para manipular as relações entre os intervalos. As operações básicas do modelo estendido são mostradas na Figura 3.7.

Este modelo permite que se defina tanto a duração de objetos de mídia dependentes de tempo quanto a duração de objetos de mídia não dependentes de tempo. Dessa forma, é possível definir, por exemplo, a duração de uma interação com o usuário. A facilidade de manipular interações com o usuário é um dos pontos fortes deste modelo.

Usando o modelo avançado de sincronização baseado em intervalos pode-se especificar, por exemplo, a apresentação de um slide show, onde Slidei $(1 \leq i \leq n)$ e um objeto de áudio possuem as seguintes relaçð̃es temporais:

Slides co-início(0) Áudio

Slidei antes $(0)$ Slide $i+1(1 \leq i \leq n-1)$ 
Operações com um parâmetro de atraso

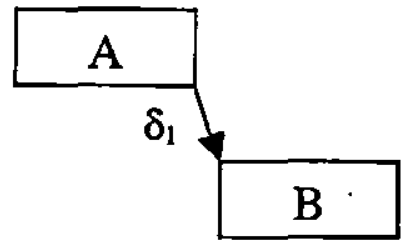

before $\left(\delta_{1}\right)$

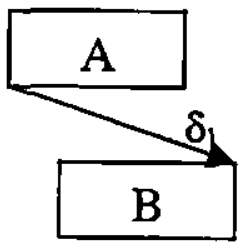

beforeendof $\left(\delta_{1}\right)$

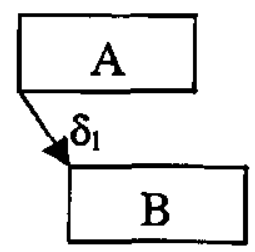

$\operatorname{cobegin}\left(\delta_{1}\right)$

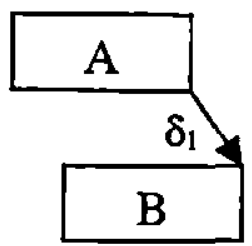

$\operatorname{coend}\left(\delta_{1}\right)$

Operações com dois parâmetros de atraso

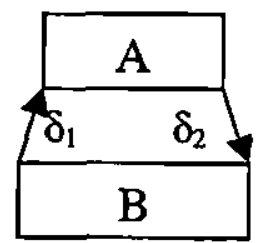

while $\left(\delta_{1}, \delta_{2}\right)$

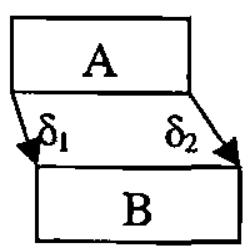

delayed $\left(\delta_{1}, \delta_{2}\right)$

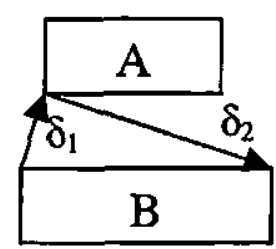

$\operatorname{startin}\left(\delta_{1}, \delta_{2}\right)$

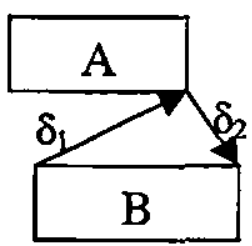

$\operatorname{endin}\left(\delta_{1}, \delta_{2}\right)$

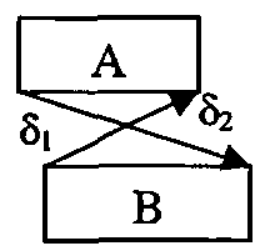

$\operatorname{cross}\left(\delta_{1}, \delta_{2}\right)$

Operações com três parâmetros de atraso

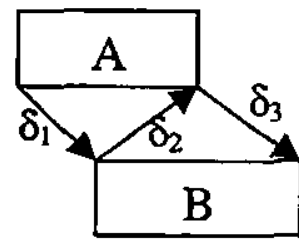

$\operatorname{overlaps}\left(\delta_{1}, \delta_{2}, \delta_{3}\right)$

Figura 3.7 - Operaçōes do modelo avançado de sincronização baseado em intervalos [WR94]

Um outro ponto forte deste modelo é a simplicidade da especificação. Para expressar a sincronização labial entre um objeto de vídeo e um objeto de áudio, basta apenas a seguinte especificação: 
As principais desvantagens deste modelo estão ligadas à falta de mecanismos que permitam a especificação de relações temporais diretamente entre as subunidades (ULDs). de cada objeto. Além disso, este modelo não suporta especificaçőes de parâmetros de skew.

\subsubsection{Especificação de Sincronização Baseada em Eixos}

Em uma especificação baseada em eixos, os eventos de uma apresentação, como o início e o fim da apresentação de uma mídia, são mapeados para eixos que são compartilhados por todos os objetos da apresentação. Existem duas formas de se especificar sincronização através do uso de eixos:

- Sincronização baseada em um temporizador global: Neste método, cada objeto de mídia é colocado em um eixo de tempo que representa uma abstração do tempo real. Este método de especificação é usado, por exemplo, no projeto Athena Muse [HSA89], no qual a sincronização é feita colocando-se todos os objetos em um eixo de tempo. Como os objetos são independentes uns dos outros, a remoção de um objeto não afeta a sincronização de outro. Com algumas modificações, este tipo de especificação é também usado no modelo de mídias ativas [TGD91]. Neste modelo, um tempo global é mantido, o qual é acessível a todos os objetos. Cada objeto pode mapear este tempo global para seu tempo local. Quando a distorção entre os tempos global e local excede um dado limite, é necessário fazer ressincronização com o tempo global.

- Sincronização baseada em eixos virtuais: Neste método, ao invés de se usar um único eixo que represente uma abstração do tempo real, são usados diversos eixos, criando um espaço de coordenadas virtual. Esta forma de especificação é útil quando um objeto de mídia já possui uma forma de representação própria no tempo, como as notas musicais de uma canção [SN95]. Nesta especificação, um conjunto de eixos virtuais são mapeados para eixos reais durante o processo de execução da apresentação. Um dos pontos fortes dessa especificação é que ela apresenta uma abstração adequada para conteúdos de mídia, facilitando o entendimento do usuário. O padrão HyTime, abordado no próximo capítulo, utiliza este método para especificar sincronização entre dois ou mais componentes de uma apresentação multimídia. 


\subsubsection{Especificação de Sincronização Baseada em Controle de Fluxo}

Nas especificações baseadas em controle de fluxo, o fluxo da apresentação de threads concorrentes é sincronizado em pontos pré-definidos da apresentação. Existem três formas de se especificar sincronização através do controle de fluxo [SN95]:

- Especificação hierárquica básica: Descrições de sincronização hierárquica são baseadas em duas operações de sincronização básicas: sincronização serial de ações (sequiência de slides, por exemplo) e sincronização paralela de ações (apresentação síncrona de áudio e vídeo, por exemplo). Em uma especificação de sincronização hierárquica, os objetos multimídia são representados através de uma árvore, na qual os nós denotam apresentação serial ou paralela de suas sub-árvores. A especificação hierárquica é largamente usada devido à facilidade de compreensão de sua estrutura básica. No entanto, esta especificação apresenta uma série de limitações; uma delas, e talvez a mais grave, é o fato de que cada ação só pode ser sincronizada em seu início ou seu fim. Isto significa, por exemplo, que a apresentação de subtítulos em partes de uma seqüência de vídeo requer que a seqüência seja dividida em vários componentes consecutivos.

- Especificação de sincronização através do uso de pontos de referência: Neste tipo de especificação, cada objeto de mídia é considerado como uma sequiência de unidades lógicas de dados (ULDs). O início e o fim de cada objeto de mídia, bem como o início de cada subunidade dependente de tempo desse objeto são considerados pontos de referência. A sincronização entre objetos é então definida pela conexão de pontos de referência desses objetos. Um conjunto de pontos de referência conectados é chamado ponto de sincronização. A apresentação das sub-unidades que participam de um mesmo ponto de sincronização deve ser iniciada ou finalizada quando este ponto de sincronização é alcançado. Este método de sincronização especifica relações temporais entre objetos sem fazer referência explícita ao tempo. Esta especificação permite que sejam feitas sincronizações em qualquer instante durante o processo de apresentação de um objeto. Além disso, a apresentação de objetos de duração desconhecida pode ser facilmente integrada. Esta especificação é também muito fácil de ser usada por ser extremamente intuitiva. 
- Especificação de sincronização através de Redes de Petri: É. possível especificar sincronização através do uso de Redes de Petri. Para tanto, basta estender os conceitos das Redes de Petri com especificações de duração [LG92], criando uma Rede de Petri temporizada. As regras para uma Rede de Petri temporizada são as seguintes:

- uma transição ocorre se todos os locais de entrada contêm um token não bloqueante;

- se uma transição ocorre, um token é removido de cada local de entrada e um token é adicionado a cada local de saída;

- um token adicionado a um novo local fica bloqueado durante a duração que é atribuída a este local.

Para objetos de mídia dependentes de tempo, cada local na Rede de Petri representa uma ULD. Dessa forma, a sincronização fina pode ser modelada através da conexão de ULDs apropriadas.

\subsubsection{Especificação de Sincronização Baseada em Eventos}

No caso da sincronização baseada em eventos, as ações de apresentação são iniciadas por eventos de sincronização. Ações típicas de apresentação são:

- inicie uma apresentação;

- interrompa uma apresentação;

- prepare uma apresentação.

Os eventos que iniciam ações de apresentação podem ser externos (gerados por um timer, por exemplo) ou internos à apresentação, gerados por um objeto de mídia dependente de tempo que alcançou uma ULD específica. Este modelo de especificação é facilmente estendido a novos tipos de sincronização. O padrão MHEG-5, a ser discutido no capítulo 4, utiliza este modelo de sincronização para apresentação de objetos de mídia que possuem relações temporais. 


\subsection{Sincronização em Ambientes Distribuídos}

A sincronização em um ambiente distribuído é mais complexa que em um ambiente local. Isto ocorre devido ao armazenamento distribuído das informações de sincronização e dos objetos de mídia envolvidos em uma apresentação. O processo de comunicação entre os locais de armazenamento e apresentação introduz atrasos e jitter adicionais, que devem ser considerados no processo de apresentação.

No local de apresentação, os componentes do sistemas precisam ter disponíveis as informações de sincronização de um objeto de mídia no momento em que este objeto deve ser apresentado. Existem três formas básicas de se enviar informações de sincronização a um local de apresentação, são elas [SN95]:

- Envio de toda a informação de sincronização antes do início da apresentação: Esta técnica é freqüientemente usada no caso de sincronização sintética. Neste caso, a aplicação que está sendo executada no local de apresentação acessa a camada de objeto passando a especificação previamente recebida, ou uma referência a ela, como parâmetro. Esta técnica tem como vantagem a facilidade de implementação e como desvantagem o atraso gerado antes do início da apresentação (tempo gasto no recebimento da especificação de sincronização).

- Uso de um canal adicional de sincronização: Este método é usado quando se deseja sincronizar objetos de mídia que estão sendo gerados em tempo real a partir de uma única fonte. Neste caso, a informação de sincronização de um dado objeto não é previamente conhecida, estando geralmente disponível apenas no momento em que o objeto deve ser apresentado, o que traz maior complexidade ao processo de sincronização. A vantagem dessa técnica é que nela as informações de sincronização não são responsáveis pelo atraso na apresentação de objetos multimídia.

- Uso de streams de dados multiplexados: Esta técnica baseia-se na multiplexação de dois ou mais streams de dados em um único canal de comunicação. A vantagem da multiplexação é que as informações de sincronização são enviadas juntamente com as unidades de mídia. Este procedimento não gera nenhum atraso adicional e dispensa o uso de um canal extra para a 
informação de sincronização. Por outro lado, é difícil usar este método quando os objetos de mídia que devem ser sincronizados estão armazenados em locais diferentes. Um exemplo de multiplexação de streams é o padrão MPEG [Key94], onde um único stream combina áudio, vídeo e informações de sincronização entre as duas mídias.

\subsection{Qualidade de Serviço}

$\mathrm{Na}$ Seção 2.6, os aspectos genéricos a respeito de qualidade de serviço ( $Q o S$ ) foram apresentados. Nesta seção, o assunto qualidade de serviço é abordado com relação à sincronização intermídia. A qualidade de serviço está presente tanto na sincronização intramídia, envolvendo objetos de mídia isolados, quanto na sincronização intermídia, onde dois ou mais objetos de mídia possuem relações temporais.

A especificação de $Q o S$ para um objeto de mídia inclui a qualidade que cada uma de suas ULDs deve apresentar, bem como a precisão das relações temporais entre as ULDs desse objeto, caso o mesmo seja um objeto de mídia dependente de tempo. Assim, se uma especificação de $Q o S$ para um stream de vídeo determina que sejam mostrados 30 frames por segundo, então cada frame deve ser exibido por exatamente 1/30 segundos a fim de se atender à especificação de qualidade de serviço requisitada.

Parâmetros de $Q o S$ são também importantes na sincronização intermídia. Estes parâmetros são usados, por exemplo, para indicar o máximo skew permitido na apresentação síncrona de duas mídias. Dessa forma, para uma apresentação de áudio e vídeo que envolva sincronização labial, o parâmetro skew não deve ser superior a $80 \mathrm{~ms}$. A Tabela 3.2 mostra alguns valores de $Q o S$ usados na sincronização de pares de mídia. 
Tabela 3.2 - Qualidade de Serviço para propósitos de sincronização [SN95]

\begin{tabular}{|c|c|c|c|}
\hline \multirow{6}{*}{ Vídeo } & Animação & Correlacionado & $t /-120 \mathrm{~ms}$ \\
\hline & Áudio & Sincronização Labial & $+/-80 \mathrm{~ms}$ \\
\hline & \multirow{2}{*}{ Imagem } & Sobreposto & $+/-240 \mathrm{~ms}$ \\
\hline & & Não-sobreposto & $+/-500 \mathrm{~ms}$ \\
\hline & \multirow{2}{*}{ Texto } & Sobreposto & $H-240 \mathrm{~ms}$ \\
\hline & & Não-sobreposto & $+/-500 \mathrm{~ms}$ \\
\hline \multirow{8}{*}{ Áudio } & Animaçāo & Correlação de eventos (dança) & $+/-80 \mathrm{~ms}$ \\
\hline & \multirow{3}{*}{ Áudio } & Fortemente acoplados (stereo) & $+11 \mu s$ \\
\hline & & $\begin{array}{l}\text { Fracamente acoplados (modo de } \\
\text { diálogo com vários participantes) }\end{array}$ & $+/-120 \mathrm{~ms}$ \\
\hline & & $\begin{array}{l}\text { Fracamente acoplados (música em } \\
\text { background) }\end{array}$ & $+/-500 \mathrm{~ms}$ \\
\hline & \multirow{2}{*}{ Imagem } & $\begin{array}{l}\text { Fortemente acoplados (música com } \\
\text { respectivas notas musicais) }\end{array}$ & $+1-5 \mathrm{~ms}$ \\
\hline & & Fracamente acoplados (slide show) & $H-500 \mathrm{~ms}$ \\
\hline & Texto & Anotação textual & $+1-240 \mathrm{~ms}$ \\
\hline & Ponteiro & $\begin{array}{l}\text { Áudio relacionado ao item que o } \\
\text { ponteiro aponta }\end{array}$ & $+-500 \mathrm{~ms}$ \\
\hline
\end{tabular}

\subsection{Considerações Finais}

Este capítulo apresentou conceitos básicos relacionados ao tema sincronização multimídia. Os conceitos apresentados visam fornecer o embasamento teórico para o entendimento do trabalho descrito neste documento.

A apresentação simultânea de dois ou mais objetos de mídia em um sistema que suporte programação multithreading é uma tarefa relativamente simples, desde que não existam dependências temporais entre tais objetos. No entanto, não faz sentido falar em uma apresentação 
multimídia que não possua relações temporais entre seus componentes. Logo, todo e qualquer sistema que se proponha a apresentar objetos multimídia deve ser capaz de interpretar e executar especificações de sincronização.

Um sistema apresentador de objetos multimídia deve ser capaz de interpretar e executar não somente especificações de sincronização intermídia, como também especificações de sincronização intramídia. Tais especificações são também chamadas de parâmetros de qualidade de serviço, uma vez que através delas pode-se especificar, por exemplo, a qualidade da apresentação de um stream de áudio ou de vídeo.

O trabalho descrito neste documento usa os conceitos apresentados neste capítulo a fim de prover sincronização inter e intramídia na apresentação de composições multimídia. 
"A primeira lei da natureza é a tolerância - já que temos todos uma porção de erros e fraquezas."

Voltaire

\subsection{Considerações Iniciais}

O mercado de aplicações multimídia é, atualmente, composto por inúmeros fabricantes que utilizam tecnologia proprietária para a codificação e o armazenamento de tais aplicações. No entanto, os sistemas de comunicação atuais que interligam várias redes são constituídos por uma grande diversidade de tecnologias que interoperam. Em sistemas heterogêneos como estes, a interoperabilidade só é alcançada quando são utilizados padrões abertos. Deste modo, tornou-se necessária a criação de padrões que permitam a reutilização de objetos multimídia em diferentes ambientes, por diferentes aplicações.

Este capítulo apresenta alguns destes padrões, como é o caso do MHEG, do HyTime e do SML, que são abordados nas Seções 4.2, 4.3 e 4.4, respectivamente. A Seção 4.5 traz um comparativo desses três padrões, abordando suas potencialidades e similaridades. Finalmente, a Seção 4.6 fecha este capítulo, traçando algumas considerações a respeito da importância dos padrões no contexto do intercâmbio multimídia.

\subsection{MHEG}

O padrão MHEG (acrônimo de Multimedia and Hypermedia information coding Expert Group) representa um esforço da ISO para a definição de representação e codificação de objetos multimídia e hipermídia com o objetivo de permitir o intercâmbio desses objetos por aplicações e serviços.

O padrão MHEG é, atualmente, composto por seis partes - partes 1 a 7 , exceto a parte 2 . A parte 2 do padrão MHEG foi cancelada antes de alcançar o status de padrão internacional. $O$ MHEG-2 definiria a codificação do MHEG-1 através da linguagem SGML, permitindo o 
intercâmbio de dados estruturados entre sistemas, independentemente de aplicações. A seguir são descritas as seis partes do padrão MHEG:

- Parte 1: Representação de objetos MHEG, usando a notação ASN.1.

O MHEG-1 define objetos multimídia, seus comportamentos, as ações que lhes podem ser aplicadas e suas representações de intercâmbio no formato ASN.1 (Abstract Syntax Notation One) [ISO90a] [ISO90b], permitindo que interpretadores MHEG possam compartilhar tais objetos. O MHEG-1 não permite, como o MHEG-5, um formato textual alternativo de representação. A complexidade do formato adotado levou à não aceitação comercial desta parte do padrão.

- Parte 3: Representação do intercâmbio de scripts MHEG.

O MHEG-3 define a representação, codificação e semântica de scripts capazes de serem intercambiados como parte de uma aplicação MHEG. Define também os requisitos mínimos que uma máquina MHEG deve possuir para suportar a interpretação de tais scripts. Os objetos script devem ser interpretados por uma máquina virtual, chamada SIR (Script Interchange Representation), que deve ser independente de máquina ou sistema operacional.

- Parte 4: Procedimentos de registro MHEG.

O MHEG-4 define o procedimento de registro para objetos e formatos suportados pelo padrão MHEG.

- Parte 5: Suporte para aplicações interativas básicas.

O MHEG-5 tem como função principal dar suporte à aplicações multimídia interativas em ambientes de recursos mínimos. O projeto $S M m D$ [Tei94], no qual este trabalho se insere, está fundamentado nesta parte do padrão MHEG. Por este motivo, a parte 5 do padrão será abordada em detalhes na Seção 4.2.1.

- Parte 6: Suporte para aplicações interativas avançadas. 
O MHEG-6 foi criado para estender a parte 5 do padrão provendo capacidade de processamento e funçōes de comunicação. Para tanto, o MHEG-6 representa objetos do tipo programas e applets usando a representação bytecode da linguagem Java como formato de intercâmbio. Isto torna necessária a presença da máquina virtual Java dentro da máquina MHEG-6, bem como um conjunto de APIs básicas (java.lang, java.util, java.io) cuja função é prover acesso às funcionalidades da plataforma hospedeira. Além disso, existe uma API específica, denominada iso.mheg5, que permite que um programa Java possa acessar os objetos de uma aplicação MHEG-5 e as funcionalidades da máquina MHEG-5.

- Parte 7: Interoperabilidade e testes de conformidade.

A parte 7 do padrão MHEG ainda está em fase de desenvolvimento. Seu objetivo é especificar testes de interoperabilidade e conformidade para máquinas e aplicações MHEG-5. Para este propósito, além de definir um conjunto de testes de interoperabilidade e conformidade, 0 MHEG-7 também define objetos e uma máquina MHEG-5 de referência. O objetivo desta parte do padrão é fornecer urn guia claro e não ambíguo para a implementação de aplicações e máquinas, promovendo assim, um incentivo ao desenvolvimento de aplicações e ferramentas MHEG-5.

A seção a seguir faz uma abordagem detalhada da parte 5 do padrão MHEG, uma vez que o MHEG-5 foi o padrão eleito para representar intercâmbio multimídia no contexto do projeto $\mathrm{SMmD}$.

\subsubsection{O MHEG-5}

O padrão MHEG-5 [ISO97] foi desenvolvido para suportar a distribuição de objetos multimídia interativos em arquiteturas cliente-servidor com plataformas de diferentes tipos [JR95]. O MHEG-5 define uma forma final de representação para o intercâmbio de objetos. Estes objetos consistem basicamente de código declarativo, apesar de existirem meios de se fazer chamadas a codigos procedurais. Os objetos MHEG-5 passam pelo processo de autoria uma única vez e podem rodar em qualquer plataforma que suporte o padräo. 
A principal função do padrão MHEG-5 é definir a sintaxe e a semântica de um conjunto de classes de objetos que possam ser usados para a interoperabilidade de aplicações multimídia entre plataformas de recursos mínimos, como é o caso, por exemplo, da TV interativa.

O funcionamento básico da arquitetura definida pelo padrão MHEG-5 é simples. Os objetos MHEG-5 são mantidos em um servidor. Quando um cliente deseja carregar um objeto ele solicita este objeto ao servidor que faz a transferência do mesmo para o cliente requisitante. O objeto não é enviado de uma só vez através da rede, e sim por partes, de acordo com a necessidade do cliente. Ao chegar no cliente, o objeto MHEG é decodificado, interpretado e apresentado por um run-time engine que se encarrega também de gerenciar as interações com o usuário. A Figura 4.1 mostra o processo de intercâmbio de objetos multimídia no MHEG-5.

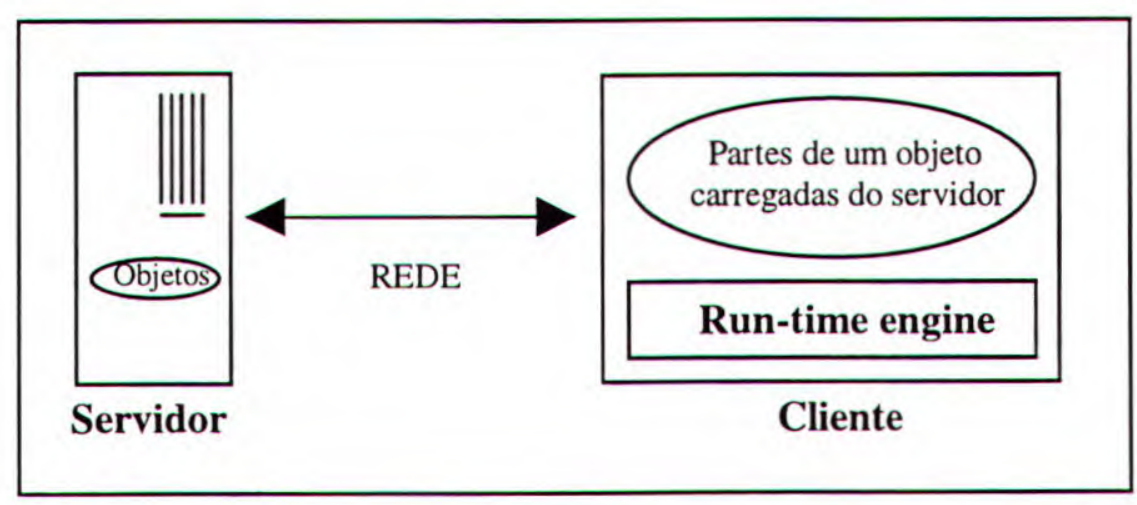

Figura 4.1 - Aplicação MHEG em um servidor, com partes carregadas em um cliente [JR95].

O padrão MHEG-5 é direcionado para alguns tipos particulares de aplicações, como vídeo em demanda, notícias em demanda, home-shopping interativo, etc. Os maiores objetivos do MHEG5 são os seguintes [JR95]:

- Prover um padrão para o desenvolvimento de aplicações multimídia cliente-servidor destinadas a rodar em plataformas com recursos mínimos; 
- Definir uma forma final de representação codificada para o intercâmbio de objetos entre plataformas de diferentes tipos;

- Prover as bases para um nível de conformidade concreta, garantindo que um objeto em conformidade com o padrão MHEG-5 irá rodar em todos os terminais em conformidade com este padrão;

- Permitir que o run-time engine do cliente seja "pequeno" e "fácil" de implementar;

- Impedir que as limitações na arquitetura dos clientes influencie o desenvolvimento das aplicações;

- Permitir o desenvolvimento de uma ampla variedade de aplicações. Isto significa prover acesso a bibliotecas externas. Uma aplicação usando bibliotecas externas é apenas parcialmente portável:

- Garantir que o código de um objeto seja seguro, ou seja, que este código não irá danificar nenhum outro código no cliente, e nem tão pouco colocar o cliente em um estado anormal;

- Promover o desenvolvimento rápido de aplicações através da disponibilização de primitivas de alto nível e de um paradigma declarativo para o desenvolvimento de aplicações.

A próxima seção apresenta uma visão geral da hierarquia de classes do padrão MHEG-5.

\subsubsection{A Hierarquia das Classes MHEG-5}

A informação contida em uma aplicação MHEG-5 é estruturada segundo a hierarquia de classes apresentada na Figura 4.2. Esta figura utiliza a simbologia definida no modelo OMT (Object Modeling Tecnique) [Rum91] para representar graficamente a relação de hierarquia das classes MHEG-5. A Tabela 4.1 mostra as estruturas utilizadas para representar a hierarquia e os relacionamentos entre as classes MHEG-5. 
Tabela 4.1 - Legenda do diagrama da hierarquia de classes do padrão MHEG-5

\begin{tabular}{|l|l|}
\hline Link & $\begin{array}{l}\text { Classe Concreta } \\
\text { Nome da classe em negrito }\end{array}$ \\
\hline Visible & $\begin{array}{l}\text { Classe abstrata } \\
\text { Nome da classe em estilo normal }\end{array}$ \\
\hline \hline & $\begin{array}{l}\text { Relacionamentos de herança ou generalização de } \\
\text { classes }\end{array}$ \\
\hline & $\begin{array}{l}\text { Relacionamentos de composição ou agregação de } \\
\text { classes }\end{array}$ \\
\hline & Multiplicidade de associações \\
\hline
\end{tabular}

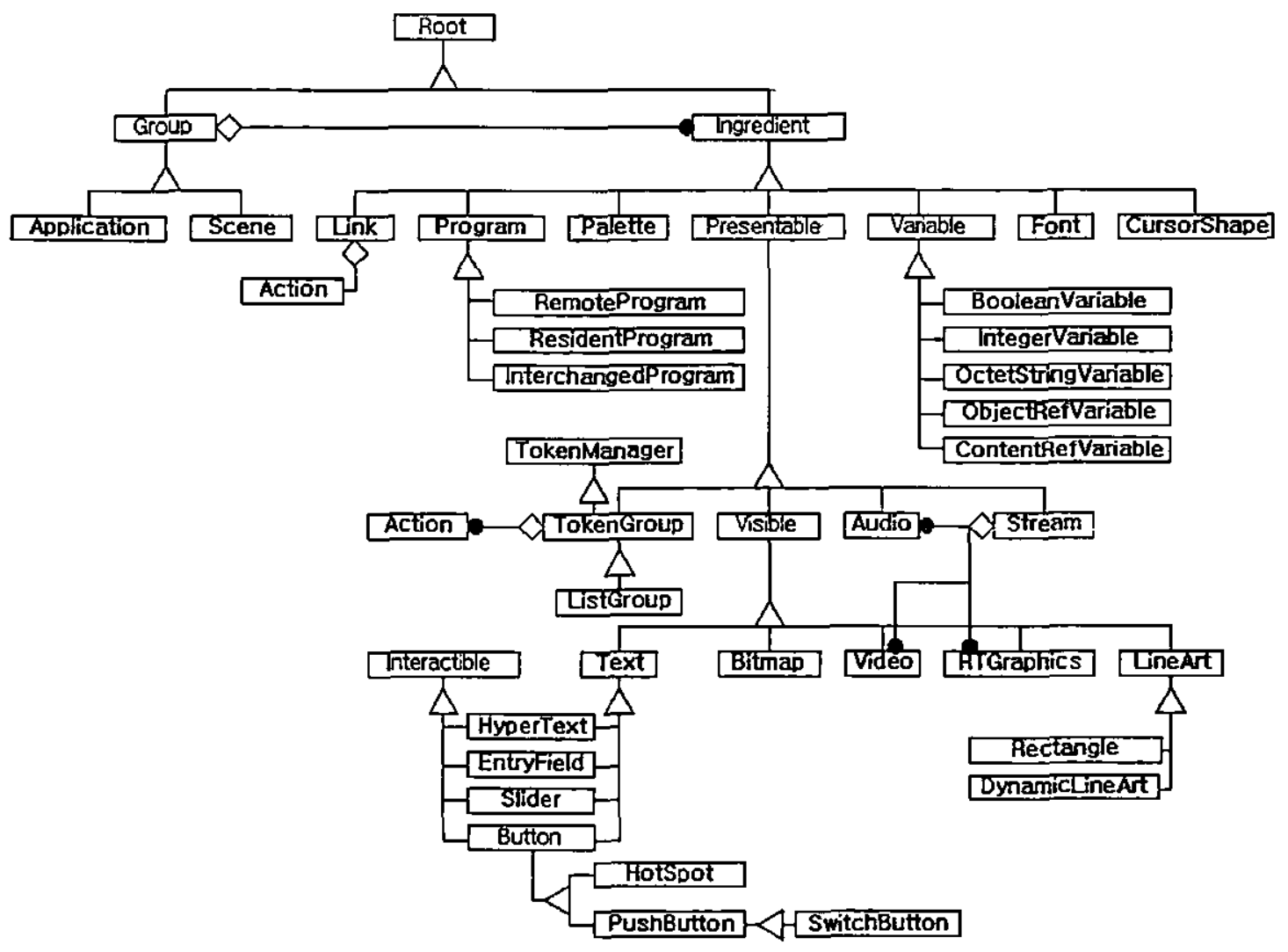

Figura 4.2 - Diagrama da hierarquia de classes MHEG-5. 
As classes básicas da hierarquia MHEG-5, juntamente com outras, importantes no contexto do trabalho desenvolvido nesta dissertação, são abordadas a seguir:

\section{- Root}

Superclasse abstrata, comum a todas as classes MHEG-5. Serve para prover um mecanismo uniforme de identificação de objetos e especifica uma semântica geral para a preparação/destruição e ativação/desativação de objetos, incluindo a notificação de mudanças na disponibilidade de um objeto e em seu RunningStatus (propriedade de um objeto MHEG5 que serve para determinar se o mesmo está ou não em execução em um dado momento). Estes mecanismos gerais de funcionamento dos objetos são então especializados à medida que se desce na hierarquia de classes.

\section{- Group}

Classe abstrata que gerencia o agrupamento de objetos da classe Ingredient, fazendo com que estes objetos se tornem uma única entidade de intercâmbio. Objetos do tipo Group podem ser endereçados e recuperados independentemente de um servidor. Um objeto do tipo Group pode ser especializado em objetos Scene e Application, conforme mostra a Figura 4.2.

\section{- Ingredient}

Classe abstrata que fornece atributos comuns a todos os objetos que podem ser incluídos em uma aplicação ou cena. Objetos como bitmap, text, button, audio, video, etc., são definidos como instâncias de subclasses da classe Ingredient.

Esta classe define atributos relacionados ao conteúdo, formato de codificação e tamanho de um objeto. Define ainda se um objeto deve ser iniciado em seu estado ativo ou não e se um objeto deve permanecer ativado durante a transição entre cenas.

As classes Link, Program, Variable, Presentable, Palette, Font e Cursor Shape são subclasses da classe Ingredient, conforme mostra a Figura 4.2. 


\section{- Application}

Uma aplicação MHEG-5 é organizada estruturalmente em um objeto Application e um ou mais objetos Scene. O objeto Application representa o ponto de entrada que realiza a transição para a primeira cena de uma apresentação. Geralmente, esta transição ocorre com a execução da ação OnStartUp, que é automaticamente invocada quando o objeto Application se torna ativo.

Os objetos dessa classe são grupos de objetos da classe Ingredient que podem estar presentes em várias cenas, permitindo assim, uma apresentação contínua de conteúdos de mídia (por exemplo, um bitmap pode servir de papel de parede para todas as cenas de uma aplicação).

\section{- Scene}

Classe que tem por função permitir a apresentação multimídia de acordo com eixos temporais e espaciais. Assim como acontece com a classe Application, apenas um objeto da classe Scene pode estar ativo em um dado momento. A navegação através das cenas de um objeto Application é realizada através da ação TransitionTo, a qual fecha a cena corrente, inclusive seus objetos, e ativa uma nova cena.

O atributo Scene CoordinateSystem especifica o espaço de apresentação 2D para uma cena. Se uma interação do usuário ocorre neste espaço, um evento do tipo Userlnput é gerado. Uma cena também suporta temporizadores (timers). Um evento do tipo Timer ocorre quando um temporizador expira.

\section{- Presentable}

Classe abstrata que especifica atributos comuns para objetos que encapsulam informação que pode ser vista ou ouvida pelo usuário. As ações Run e Stop ativam e terminam a apresentação de objetos desta classe, gerando os eventos IsRunning e IsStopped. 
As classes Audio, Visible, TokenGroup e Stream são especializações da classe Presentable, como mostra a Figura 4.2.

\section{- Visible}

Classe abstrata que especializa a classe Presentable provendo recursos para apresentação de objetos dentro do espaço 2D definido por uma cena. Os atributos OriginalBoxSize e OriginalPosition definidos nesta classe especificam, respectivamente, o tamanho e a posição de uma caixa que contém um objeto em relação ao espaço de apresentação da cena. As ações SetSize e SetPosition modificam os valores correntes desses atributos.

A classe Visible possui alguns objetos especializados, detalhados a seguir.

\section{- Bitmap}

Objeto responsável por apresentar um vetor bidimensional de pixels. Possui um atributo chamado Tiling, que especifica se o conteúdo gráfico deverá ser replicado ou não na caixa definida para conter o objeto. Possui também uma ação, chamada ScaleBitmap, cuja função é alterar o tamanho do objeto.

\section{$\bullet$ LineArt e DynamicLineArt}

LineArt é um objeto responsável por definir a funcionalidade associada com a representação vetorial de objetos gráficos. $O$ objeto DynamicLineArt provê recursos para se gerar, automaticamente e em tempo de execução, linhas e curvas em uma área retangular pré-definida.

\section{$\downarrow$ Text}

Objeto que representa uma string de texto que possui um conjunto de atributos de apresentação associados. Estes atributos especificam tipos de fonte e formatação que devem ser aplicados à string. 


\section{- Interactible}

Classe abstrata cuja principal função é permitir ao usuário interagir com objetos de suas subclasses, que são as seguintes:

\section{- Hotspot, PushButton e SwitchButton}

Estas subclasses implementam capacidades de seleção de botões e geram o evento IsSelected para indicar a interação do usuário com seus objetos.

\section{$\bullet$ Hypertext}

Esta classe estende a classe Text provendo o conceito de âncoras. Quando selecionadas, estas âncoras ligam um conteúdo de texto a outra informação associada.

\section{- Slider}

Classe responsável por prover objetos gráficos usados para ajustar um valor numérico dentro de um intervalo específico. Um objeto, semelhante a um termômetro, que mostra, durante a transferência de um arquivo, a quantidade de dados transferidos em relação à quantidade de dados total, é um exemplo de Slider.

\section{- EntryField}

Classe responsável por prover caixas de texto com as quais os usuários podem interagir, modificando e inserindo textos.

\section{- Link}

Classe que implementa um mecanismo do tipo evento-ação através de seus objetos, os quais são constituídos de duas partes: uma condição (LinkCondition) e um efeito (LinkEffect). A LinkCondition consiste de um EventSource, que é uma referência ao objeto no qual o evento 
ocorreu, um EventType, que especifica o tipo de evento ocorrido e um possível EventData, que especifica um valor associado ao evento.

O LinkEffect consiste de um conjunto de ações que devem ser executadas em seqüência como o resultado do disparo de um Link. Cada ação deve especificar o objeto ao qual a mesma está direcionada e, possivelmente, outros parâmetros que dependem do tipo da ação a ser executada. O MHEG-5 especifica mais de 100 tipos diferentes de ações.

\section{- Stream}

Classe que controla a apresentação sincronizada de dados audiovisuais multiplexados (como um arquivo MPEG, por exemplo). Um objeto Stream consiste de uma lista de componentes das classes Video, Audio e RTGraphics (abordados a seguir).

O atributo ContentData do objeto Stream refere-se a toda multiplexação de mídias, e não a cada um de seus componentes. Assim, se um Stream está sendo apresentado sob demanda, não é possível interferir na sincronização existente entre seus componentes de mídia. $O$ máximo que se pode fazer é escolher quais componentes serão apresentados. Isto significa que só é possível fazer uma ressincronização do Stream off-line, ou seja, depois que o mesmo tenha sido inteiramente recebido do servidor.

O objeto Stream possui os seguintes atributos:

- Multiplex: Lista de objetos multiplexados (objetos das classes Video, Audio e RTGraphics);

- Storage: Indica se uma composição de mídia contínua deve ser carregada na memória para depois ser apresentada, ou se ela deve ser apresentada sob demanda, à medida que é transferida de um servidor;

- Looping: Indica o número de vezes que o Stream deverá ser apresentado em sequência; 
- Speed: Fornece a velocidade na qual um stream é apresentado. Esta velocidade pode ser alterada através da ação SetSpeed;

- CounterPosition: Fornece a posição temporal do frame corrente de um stream em relação ao seu tempo total de apresentação em velocidade normal. A unidade de medida desta posição temporal depende da implementação utilizada. As implementaçōes realizadas no contexto dessa dissertação utilizam milissegundos como unidade temporal a fim de manter compatibilidade com a API JMF Player (abordada no Apêndice B). O atributo CounterPosition pode ser ajustado através da ação SetCounterPosition;

- CounterEndPosition: Fornece a posição temporal do último frame do stream a ser apresentado, também em relação ao seu tempo total de apresentação em velocidade normal. Este atributo pode ser ajustado através da ação SetCounterEndPosition;

- CounterTriggers: Lista de valores representando posições temporais nas quais o player responsável pela apresentação do stream deverá gerar eventos do tipo CounterTrigger. Esta lista é gerada através da ação SetCounterTrigger.

Como já foi dito anteriormente, um objeto Stream pode ser composto por objetos das classes Audio, Video e RTGraphics. Essas três classes são sucintamente descritas a seguir.

\section{- Audio}

Define atributos e ações relacionadas a um stream de áudio, que deve ser componcntc de um objeto Stream. Possui o atributo Volume, utilizado para ajustar o volume de apresentação. Este ajuste é feito através da ação SetVolume. A ação GetVolume tem como função obter o volume corrente de uma apresentação.

\section{- Video}

Define atributos e ações relacionadas a um stream de vídeo que deve, assim como o objeto Audio, ser componente de um objeto Stream. Esta classe define a ação 
ScaleVideo(XScale, YScale), cuja função é adaptar a janela de apresentação do vídeo de forma que o mesmo preencha as dimensōes fornecidas por XScale e YScale.

\section{- RTGraphics}

Define atributos e ações relacionadas a objetos gráficos não persistentes, definidos como um stream elementar de um objeto Stream multiplexado.

A próxima seção apresenta um exemplo de aplicação MHEG-5 que ilustra o funcionamento da hierarquia de classes apresentada.

\subsubsection{Exemplo de Aplicação MHEG-5}

Uma aplicação multimídia pode ser vista como um conjunto de objetos interconectados através de relações espaciais, temporais e de sincronização que envolvem múltiplos formatos de mídia, composição estrutural, associaçōes do tipo "evento-ação", navegação e interação do usuário. Controlar a apresentação de conteúdos de mídia dependentes de tempo, como streams de áudio e/ou vídeo, requer suporte específico. A apresentação desses streams demanda não apenas funções de controle como as existentes em um vídeo cassete (play, pause, fast-forward, etc.), como também a capacidade de manipular eventos gerados durante sua apresentação [Ech98].

O padrão MHEG-5 representa uma aplicação, ou objeto multimídia, como um conjunto de cenas, sendo que uma aplicação pode conter objetos comuns a todas as cenas. Uma cena é responsável pela apresentação temporal e espacial de conteúdo audiovisual, como imagens, textos e streams de áudio e vídeo. A interação entre uma cena e o usuário se dá através de elementos gráficos como botōes, sliders e caixas de texto. Cada cena, assim como seus componentes e a aplicação que a contém, são entidades capazes de expressar comportamento através do uso de links, que são associações do tipo "evento-ação". Eventos podem ser gerados pelos usuários, pela expiração de um timer, pela apresentação de um stream e devido a condições internas da máquina MHEG.

Um exemplo de aplicação MHEG-5 é mostrado na Figura 4.3. Esta aplicação, chamada "Produção de Mídia Digital", aborda o uso de equipamentos de áudio e vídeo para aquisição de 
imagens e sons e sua posterior digitalização. A Figura 4.3 mostra um recorte de tela capturado no momento da exibição do objeto "cenal".

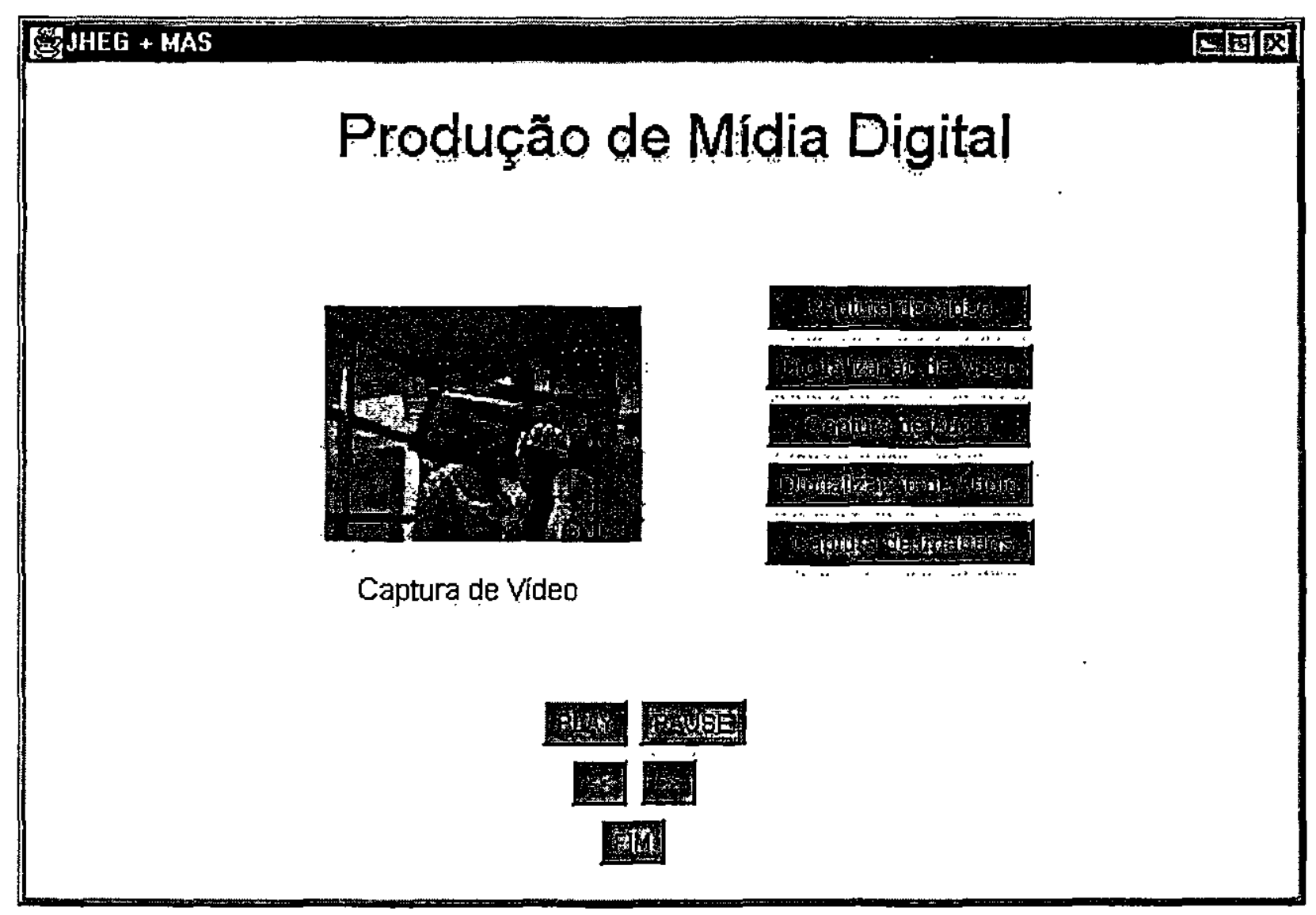

Figura 4.3 - Recorte de tela da aplicação "Produçāo de Mídia Digital"

Esta cena consiste de:

- Um texto de título;

- Um video clip, que apresenta os equipamentos usados na captura e digitalização de mídias contínuas;

- Um subtítulo, abaixo da janela de apresentação do vídeo, que fornece informações adicionais a respeito das imagens mostradas; 
- Botões de interação, à direita da janela do vídeo, usados para ativar porções específicas do video clip;

- Um conjunto de botões, na parte inferior da tela, que provêem funções de controle similares àquelas de um vídeo cassete;

- Um botão que permite encerrar a cena.

Os objetos da cena descrita se relacionam da seguinte maneira:

- Os subtítulos, mostrados abaixo da janela do vídeo, são sincronizados com a apresentação do stream de vídeo. Assim, toda vez que um assunto novo é abordado no vídeo, o subtítulo é automaticamente modificado;

- Os botões de interação servem para ativar um trecho específico do vídeo clip. Dessa forma, se o usuário clicar no botão "Digitalização de Vídeo", o stream será apresentado a partir do primeiro frame que aborda o assunto escolhido;

- Os botões de controle manipulam a exibição do video clip, provendo funções como apresentar (play), parar (pause) e adiantar (>>).

O padrão MHEG-5 é estruturado de acordo com um modelo orientado a objetos. Neste modelo, as ações são métodos relacionados a objetos de diferentes classes, usadas para prover um comportamento específico, como por exemplo, preparação e ativação de objetos, controle de uma apresentação ou de ações do usuário, etc. A fim de permitir interoperabilidade entre sistemas heterogêneos, o MHEG-5 especifica uma sintaxe precisa de codificação para suas aplicações, permitindo o uso de duas notações: a notação ASN.1, também usada na parte 1 do padrão MHEG, e uma notação textual. A Figura 4.4 mostra trechos da notação textual usada na aplicação "Produção de Mídia Digital". O código completo dessa aplicação encontra-se disponível no Apêndice A. 


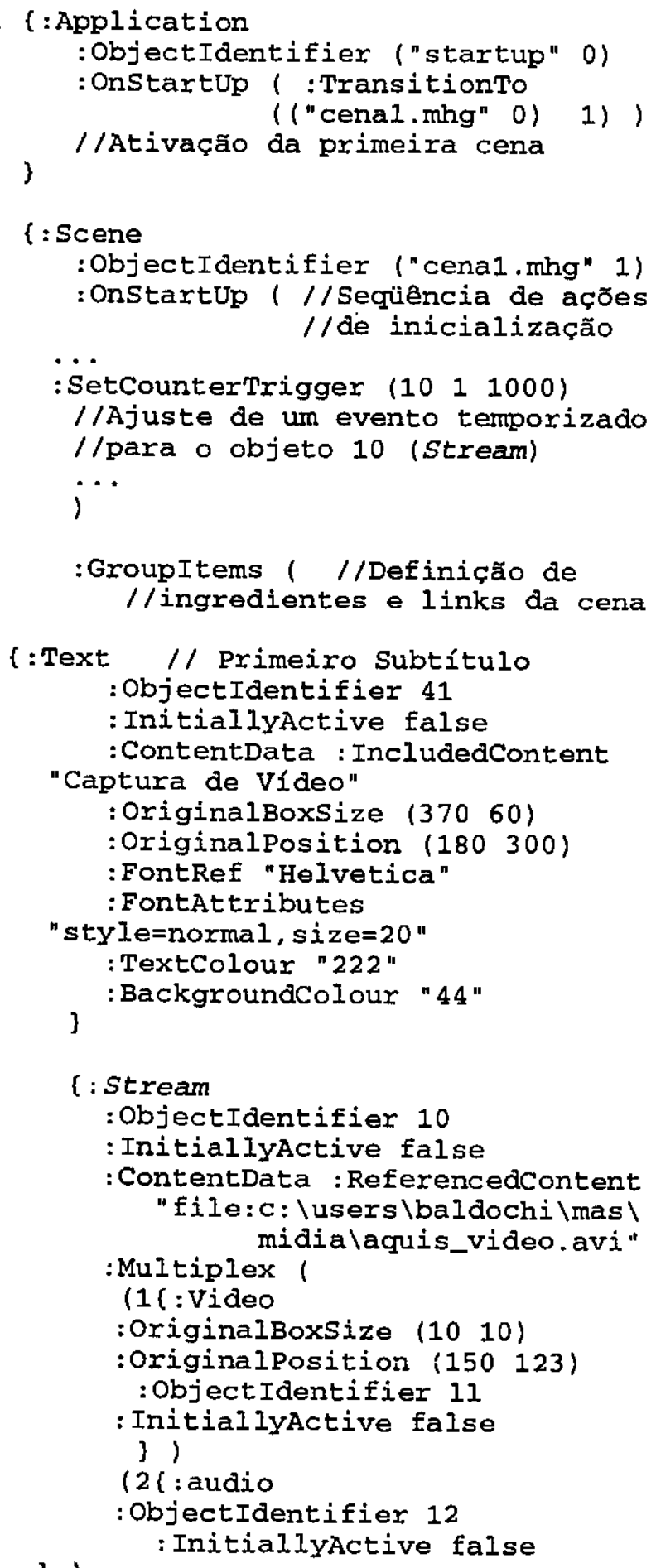

Figura 4.4 - Parte da notaçāo textual da aplicaçāo "Produçāo de Mídia Digital" 
A aplicação "Produção de Mídia Digital" é composta por dois arquivos, chamados "startup" e "cenal.mhg". O arquivo "startup" contém o objeto application, que representa o ponto de entrada a partir do qual se dá a transição para a primeira (e única) cena da aplicação. Esta transição é feita através da ação TransitionTo, que é invocada no momento do carregamento do arquivo startup, pois é neste momento que a ação OnStartUp é executada. O objeto application se encontra definido entre as linhas 01 e 06 da Figura 4.4.

Entre as linhas 08 e 104 encontra-se definido o objeto Scene, chamado "cenal". No processo de startup do objeto Scene são definidos uma série de eventos temporizados através da ação SetCounterTrigger. A Figura 4.4 mostra um desses eventos na linha 13. A ação SetCounterTrigger $\left(\begin{array}{lll}10 & 1 & 1000\end{array}\right)$ especifica que um link deve ser disparado toda vez que o objeto Stream alcançar a posição de 1 segundo de exibição em relação ao seu tempo total.

A seguir, a partir da linha 19, são agrupados todos os ingredientes do objeto Scene. Inicialmente aparecem os ingredientes do tipo Presentable, como Text (linha 22), stream (linha 36) e PushButton (linha 59). A seguir, são declarados 26 objetos do tipo Link, dos quais dois são mostrados nas linhas 70 e 83 .

Cada um dos objetos Ingredient possui uma série de atributos, que podem estar definidos em sua própria classe, ou podem ser herdados de suas superclasses. O objeto PushButton, por exemplo, definido entre as linhas 59 e 66 , possui os seguintes atributos:

- ObjectIdentifier: valor numérico que serve para identificar um objeto do tipo Ingredient. E herdado da classe Root;

- InitiallyActive: determina se um objeto deve ou não ser ativado no início da apresentação de uma cena ou aplicação. É herdado da classe Ingredient;

- OriginalBoxSize e OriginalPosition: determinam o tamanho e a posição de objetos visíveis. São herdados da classe Visible; 
- Label: especifica um rótulo para o objeto PushButton. É definido na própria classe PushButton.

Um outro atributo importante, que aparece na linhas 25 (objeto Text) e na linha 39 (objeto Stream), é o atributo ContentData, no qual se armazena a informação a ser exibida por um objeto. Esta informação pode estar codificada no próprio objeto ou seu código pode ser armazenado em um arquivo externo. No primeiro caso, usa-se o atributo IncludedContent para denotar que a codificação que segue consiste na informação a ser apresentada, conforme ilustra as linhas 25 e 26 . No segundo caso, usa-se o atributo ReferencedContent para denotar que a informação que segue é um endereço de um arquivo que contém a codificação de um objeto de mídia. Este caso é mostrado nas linhas 39 a 41 .

A aplicação "Produção de Mídia Digital" usa objetos do tipo Link para responder a dois tipos específicos de eventos: os gerados pela criação de CounterTriggers no processo de startup do objeto Scene, e aqueles gerados pela interação do usuário com os botões de controle da aplicação (play, pause, fast-forward, etc.). A Figura 4.4 mostra um exemplo de cada um dos tipos citados, como detalhado a seguir.

Entre as linhas 70 e 81 define-se o primeiro objeto Link. A condição para o disparo desse link, ou seja, sua LinkCondition, é que ocorra um evento no objeto cujo identificador é 10 (EventSource 10), tal evento seja um CounterTrigger (EventType CounterTrigger) e que este evento tenha uma codificação igual a l (EventData 1). Se as três condiçöes anteriores forem satisfeitas, o efeito do disparo desse Link, ou seja, seu LinkEffect, será a apresentação do objeto 41 (LinkEffect ( :Run 41)) .

Usando objetos do tipo Link é possível especificar eventos temporizados (síncronos) para um objeto específico, como um objeto Stream, ou para uma cena (neste caso usando-se timers). É possível também especificar eventos assíncronos, como a interação do usuário com botões de controle de uma aplicação. É isto que é feito entre as linhas 83 e 94 . O objeto Link criado por este código será disparado se ocorrer um evento com o objeto 61 (EventSource 61) e tal evento for a seleção desse objeto (EventType IsSelected). Neste caso, o efeito do disparo desse 
Link será a execução de duas ações elementares (um LinkEffect pode conter um número arbitrário de ações elementares), como mostram as linhas 91 a 94 da Figura 4.4.

Finalmente, o atributo SceneCoordinateSystem, definido na linha 101 , tem por função dimensionar o espaço de apresentação do objeto Scene.

O exemplo de aplicação mostrado na Figura 4.4 tem como função ilustrar o uso das principais classes do padrão MHEG-5 no contexto do trabalho desenvolvido nesta dissertação. Para se obter uma descrição mais detalhada da funcionalidade de cada classe deve-se consultar o documento do padrão MHEG-5 [ISO97].

A próxima seção aborda outros padrões usados na especificação de apresentações multimídia, como o SGML, o XML e o HyTime. Em seguida, é apresentada a recomendação SMIL.

\subsection{SGML, XML e HyTime}

HyTime (Hypermedia/Time-Based Structuring Language) [ISO92] é uma linguagem de marcação padrão usada na representação de aplicações multimídia/hipermídia e documentos baseados em tempo em termos de suas estruturas lógicas [Ste95]. O HyTime estende o padrão SGML (Standard Generalized Markup Language) [ISO76] adicionando algumas convenções sintáticas, chamadas formas arquiteturais, com as quais representa certas construções semânticas. O HyTime não pode ser entendido ou avaliado sem que se entenda, ainda que superficialmente, a importância e a utilidade do padrão SGML, no qual ele se baseia.

O XML [W3C98b], por sua vez, consiste em um subconjunto simplificado do padrão SGML, especialmente projetado com o objetivo de facilitar o uso de recursos providos pelo SGML no contexto da World Wide Web. Cada um desses padrões se encontra descrito nas seções a seguir.

\subsubsection{SGML}

O padrão SGML define uma linguagem genérica para descrição da estrutura de documentos, permitindo a criação de linguagens específicas que definem a estrutura de um tipo de documento. 
Pode-se dizer que SGML é uma meta-linguagem que permite a especificação de linguagens. Assim como a Backus Naur Form (BNF) formaliza a especificação de linguagens de programação, SGML formaliza a definição de linguagens de estruturação de documentos [Pim95].

Cada documento SGML, portanto, está associado a uma linguagem que o define. Essa linguagem é formalizada em um DTD (Document Type Definition), o qual estabelece: a) que tipos de elementos podem existir em um documento; b) que atributos esses elementos podem ter; e c) como as instâncias desses tipos estão hierarquicamente relacionadas.

A linguagem especificada em um DTD fornece apenas a estrutura logica de um documento, não sendo dada nenhuma informação a respeito da semântica de apresentação do documento. Deste modo, para um livro, por exemplo, é dada a estrutura de seus capítulos e seções, mas nada é definido a respeito do formato de apresentação das páginas, colunas, ou qual o tipo de caractere utilizado. Isso significa que é de responsabilidade da aplicação que processa um documento SGML especificar como as instâncias dos elementos devem ser visualizadas no documento final.

\subsubsection{XML}

A linguagem de marcação padrão XML (eXtensible Markup Language) [W3C98b] foi desenvolvida pelo World Wide Web Consortium (W3C) com o objetivo de permitir a especificação de documentos Web mais extensíveis, melhor estruturados e validados, uma vez que a linguagem HTML, usada na criação desses documentos, não dispōe de tais recursos.

A linguagem HTML consiste em uma especificação SGML que define um conjunto de elementos (tags) a partir dos quais é possível especificar a estrutura de documentos. A utilização de um conjunto fixo e pequeno de elementos permite que se deixe a especificação da linguagem fora dos documentos HTML, possibilitando a criação de aplicações de forma muito mais simples e rápida. Em contrapartida, esta facilidade limita a linguagem HTML em importantes aspectos, relacionados, sobretudo, com a extensibilidade, estruturação e validação de seus documentos. 
A linguagem XML se propõe a resolver tais limitações. Para tanto, seu desenvolvimento foi feito a partir do SGML, sendo considerada um subconjunto deste. A necessidade de se desenvolver uma linguagem nova a partir de algo mais amplo já existente vem do fato de que a linguagem SGML possui uma série de recursos opcionais não necessários para as aplicações desenvolvidas para a WWW, consistindo em uma razão custo/benefício pouco atraente para as empresas que desenvolvem navegadores comerciais [Bos97].

\subsubsection{HyTime}

Padrão que estende o SGML, definindo como um DTD deve ser utilizado para descrever a estrutura de hiperdocumentos baseados em ligações e objetos multimídia. O HyTime pode ser visto também como uma aplicação SGML, uma vez que é definido por um meta-DTD, o qual formaliza regras para a criação de documentos hipermídia [Pim95].

A estrutura formal de um documento HyTime deve ser considerada na criação, no processamento e no intercâmbio deste documento. Nesse contexto, HyTime é uma meta-linguagem que define regras para:

- a representação de ligações hipertexto;

- o escalonamento de eventos no espaço e no tempo;

- a sincronização desses eventos.

O padrão HyTime formaliza regras sobre objetos estruturados de informação, de modo a permitir a definição de ligações para/de componentes desses objetos através de mecanismos e modelos responsáveis pela identificação, localização e ligação dos mesmos.

Em relação à informação multimídia, o HyTime fornece mecanismos e modelos para o estabelecimento de ligações entre elementos de informação multimídia multidimensional, e para fazer o escalonamento destes elementos de informação no espaço e no tempo. 
O HyTime, assim como o SGML, não define a semântica de apresentação da informação, nada especificando sobre aspectos relativos a um tipo específico de mídia ou interface de apresentação.

O conjunto de regras definido pelo HyTime é conhecido como formas arquiteturais. Tais regras são agrupadas em seis módulos, que são os seguintes [Ste95]:

- Base Module: consiste de um agrupamento de formas arquiteturais básicas, fundamentadas no padrão SGML.

- Location Address Module: manipula a criação de ponteiros para informação, independentemente de seu tipo ou localização. É o módulo mais importante e complexo do padrão HyTime.

- Hyperlinks Module: Provê suporte para o estabelecimento de hiperligações entre partes específicas de informaçāo identificadas pelas formas arquiteturais providas pelo módulo Location Address.

- Measurement Module: serve para expressar a extensão numérica e/ou a localização de objetos em domínios mensuráveis tais como espaço, tempo e streams de dados.

- Scheduling Module: permite que eventos sejam escalonados em eixos de coordenadas definidos como finite coordinate spaces (fcs), que possuem um número arbitrário de eixos correspondentes a domínios arbitrários de medida.

- Rendition Module: estende as funções oferecidas pelo Scheduling Module, permitindo especificar como um objeto pode ser preparado para apresentação, ou como um evento de um $f c s$ pode ser mapeado em outro $f c s$.

Um hiperdocumento em conformidade com o HyTime não precisa utilizar todas as formas arquiteturais definidas pelo padrão. Uma aplicação pode incorporar apenas os módulos 
necessários ao seu hiperdocumento e omitir o resto. Para isso, todo hiperdocumento HyTime especifica, em sua declaração, quais módulos e opções são necessários ao seu processamento.

O HyTime define um engine capaz de validar documentos em conformidade com o padrão. Este engine consiste de um software que, rodando sob uma aplicação, reconhece construtores HyTime e realiza processamento independente da aplicação. Além de validar documentos HyTime, o engine deve fazer interface com servidores de bases de dados para identificar e ter acesso a âncoras, e deve também realizar os cálculos necessários para localizar eventos consistentemente num espaço de coordenadas, independente dos escalonamentos associados ou das unidades de medida associadas.

\subsection{A Recomendação SMIL}

SMIL (Synchronized Multimedia Integrated Language) [W3C98a] é uma recomendação do W3C — World Wide Web Consortium - para especificação de sincronização de objetos multimídia no contexto da WWW. Esta recomendação define mecanismos que possibilitam combinar objetos como áudio, vídeo, texto e imagens em uma única apresentação multimídia sincronizada.

A linguagem SMIL é uma linguagem de marcação bastante parecida com o HTML, e como ele, precisa apenas de um editor de texto para ser utilizada. Além disso, seu paradigma declarativo, baseado em um timeline, é bem mais simples de ser entendido que os scripts, em geral complexos, que realizam sincronização multimídia no ambiente Web [Bro98].

Uma das maiores vantagens trazidas pelo SMIL está na flexibilidade de sua arquitetura, que permite que diferentes objetos sejam transportados por diferentes protocolos. Assim, um objeto de mídia estática, como um texto ou uma imagem, pode ser recuperado através do protocolo HTTP, enquanto que um objeto de mídia contínua, como um vídeo ou um áudio, pode ser recuperado através do protocolo RTSP — Real Time Streammig Protocol [IET98] — permitindo que o stream seja apresentado sob demanda.

Outros benefícios trazidos pelo SMIL são os seguintes: 
- Conformidade com o padrão XML (eXtensible Markup Language): a aceitação pelo mercado do XML (já existem browsers comerciais que suportam este padrão) leva a crer que o mercado também venha a adotar o SMIL como padrão para a criação de apresentações multimídia baseadas na $W e b$;

- Simplicidade e facilidade de aprender: com cerca de seis elementos de layout é possível construir uma aplicação SMIL. Relações de sincronização complexas podem ser expressas com o uso de apenas dois elementos, parallel e sequential;

- Seleção de um objeto de acordo com a banda passante disponível: é possível expressar que um objeto de mídia, como um stream de áudio, por exemplo, esteja disponível em diferentes versões, cada uma delas tendo sido codificadas para uma determinada quantidade de banda passante. Isto garante que um stream seja apresentado mesmo quando existe somente uma pequena banda passante disponível;

- Seleção de idioma: é possível expressar que uma faixa de áudio esteja disponível em vários idiomas, aumentando assim a audiência potencial de um conteúdo de mídia;

- Reusabilidade de objetos de mídia: todos os componentes de uma apresentação multimídia podem ser referenciados através de URLs ao invés de serem fisicamente embutidos dentro de arquivos SMIL. Isso possibilita, por exemplo, que um vídeo armazenado em uma biblioteca de vídeos digitais possa ser reutilizado por várias apresentações;

- Balanceamento de carga: diferentes objetos de mídia de uma apresentação podem ser armazenados em diferentes servidores. Este é outro benefício trazido pelo uso de URLs ao invés de embutir objetos de mídia no corpo de documentos SMIL;

- Ligações hipertexto temporais: o SMIL oferece os mesmos recursos de hiperligações providos pela linguagem HTML, acrescentando recursos necessários à manipulação de apresentações baseadas em tempo; 
- Integração de formatos de mídia: é possível integrar qualquer formato, proprietário ou não, em um documento SMUL. Para tanto, basta que o Player SML (objeto capaz de processar dados codificados de acordo com a recomendação SMU) seja capaz de apresentar os formatos envolvidos. Isto explica porque empresas como Netscape, Microsoft e RealNetworks, que lidam com formatos proprietários e possuem interesses distintos, estão envolvidas na elaboração da linguagem SMIL.

\subsubsection{Criação de Documentos SMIL}

A linguagem SML é, como já foi dito, uma linguagem de marcação em conformidade com o padrão $X M L$, usada na apresentação de objetos multimídia dependentes de tempo. Um arquivo SML pode ser gerado por qualquer editor de texto e tem a extensão ".smi". O formato de um documento SML lembra bastante o formato dos documentos HTML, sendo que vários elementos (tags) do HTML também existem no SMIL com o mesmo nome e funções bastante semelhantes.

Todo documento SMLL deve começar com o elemento <smil> e terminar com o elemento $</$ smil $>$, da mesma forma que todo documento HTML começa com o elemento $\langle h t m l>$ e termina com o elemento $</ \mathrm{html}$. Além dessa, outras semelhanças também existem. Um documento SMLL possui área de cabeçalho, denotada pelos elementos <head> e </head> e área de corpo, situada entre os elementos $<b o d y>$ e $</ b o d y>$, onde são inseridas as informações que serão exibidas na janela do browser.

Apesar da aparente semelhança, o SMLL traz, naturalmente, uma série de elementos que não existem no HTML, como, por exemplo, audio, video, par e seq. Os dois primeiros permitem especificar a utilização de objetos de mídia contínua, que devem ser recuperados a partir de URLs. Os dois últimos, por sua vez, especificam relações de temporização e/ou sincronização entre dois ou mais objetos de mídia e são chamados elementos de sincronização.

O elemento seq é usado para expressar que vários objetos de mídia devem ser apresentados em sequiência, o que significa que os filhos de um elemento seq formam uma seqüência temporal. 
O elemento par é usado para expressar que vários elementos sincronizados ocorrem em paralelo, o que significa que os filhos de um elemento par podem ter uma ordenação temporal arbitrária, mas que deve ser mantida ao longo do tempo.

Além dos elementos audio e video já citados, os elementos ref, img, text e textstream são também elementos que representam (encapsulam) objetos de mídia, como texto, áudio, vídeo e imagens, sendo, por este motivo, chamados elementos de mídia. Um elemento de mídia pode ser incluído em um documento SMIL por referência (usando-se URLs) ou podem ser diretamente embutidos no corpo do documento. O uso de URLs é mais recomendado, uma vez que permite reusabilidade de objetos e um melhor balanceamento de carga nos servidores de mídia.

A apresentação dos objetos de mídia embutidos nos elementos acima é executada de acordo com os atributos desses elementos. Tais atributos servem para especificar a área em que uma mídia visual será exibida, o início e o fim de sua apresentação, suas relações temporais e de sincronização, enfim, toda a informação que a caracterize isoladamente e no contexto de uma apresentação multimídia. Abaixo são listados os principais atributos dos elementos que representam objetos de mídia (boa parte desses atributos são aplicáveis também aos elementos par e seq):

- begin: especifica o tempo para o início explícito de um elemento. Este atributo pode conter dois tipos de valores:

- delay-value: valor de atraso medido em tempo de apresentação (tempo de mídia) cuja semântica depende do primeiro ancestral que seja um elemento de sincronização:

- se o ancestral for um elemento par, o delay-value define um atraso a ser contado a partir do início do tempo de mídia do ancestral, como mostra a Figura 4.5;

- se o ancestral for um elemento seq, o delay-value define um atraso a ser computado a partir do fim do ancestral, conforme mostra a Figura 4.6.

- event-value: o elemento inicia quando um certo evento acontece, conforme mostra a Figura 4.7. 
$<$ par $>$

<Audio id="a" begin="6s" ... />

-..

$</$ par $>$

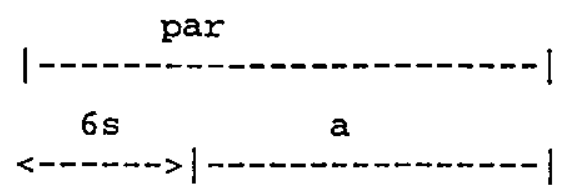

Figura 4.5 - Uso um valor de "delay" dentro de um elemento par

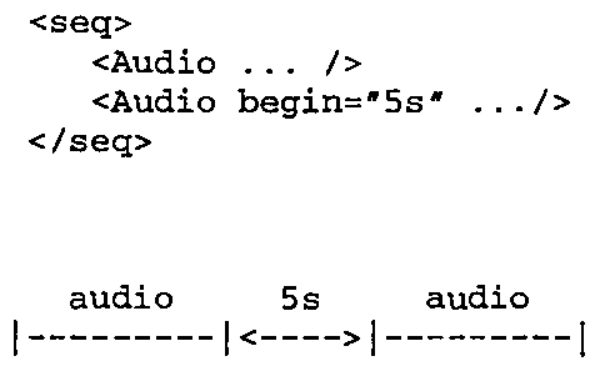

Figura 4.6 - Uso um valor de "delay" dentro de um elemento seq

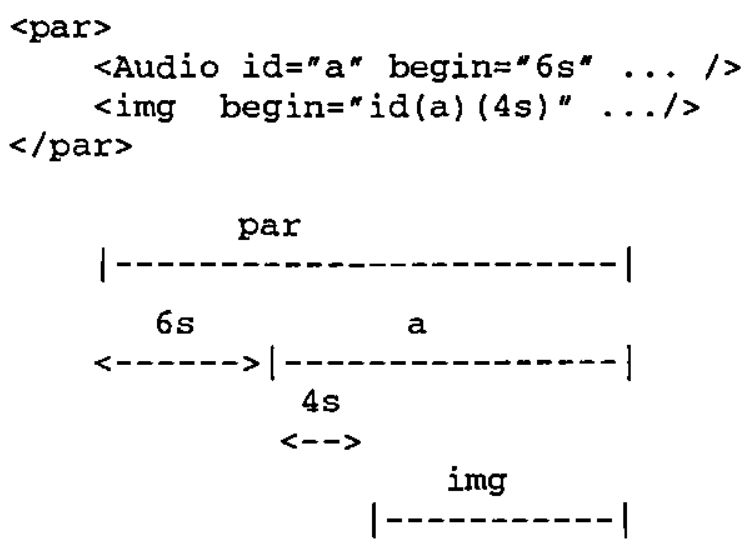

Figura 4.7 - Atributo de sincronização com o elemento event value 
Na Figura 4.7, o elemento Audio (id="a") inicia 6 segundos após um tempo inicial to. 0 elemento img, por sua vez, é iniciado 4 segundos após o início do elemento Audio, ou seja, a apresentação do elemento img depende da ocorrência de um evento no elemento Audio. Assim, se o elemento Audio não puder ser apresentado (por um problema de comunicação, por exemplo), o elemento img também não será apresentado.

- dur: Especifica a duração explícita de um elemento, que pode ser uma unidade de tempo qualquer ou a string "indefinite".

- end: Especifica o fim da apresentação de um elemento. $O$ atributo end pode ter os mesmos tipos de valores que o atributo begin.

- clip-begin: Especifica o início de um sub-clip de um objeto de mídia contínua (como um áudio ou um vídeo) a partir de um offset obtido a partir do início do objeto de mídia em questão. $O$ valor desse atributo consiste de um especificador métrico, seguido de um valor de tempo cuja sintaxe e semântica dependem do especificador métrico.

- clip-end: Especifica o fim de um sub-clip de um objeto de mídia contínua que deve ser executado. Possui a mesma sintaxe e semântica que o atributo clip-begin.

Além dos atributos citados acima, os elementos par e seq, juntamente com os elementos que representam objetos de mídia ainda possuem outros importantes atributos, como o system-bitrate e o system-language, por exemplo. Uma vez que estes atributos estão fortemente associados ao elemento switch, eles serão abordados após sua apresentação, mais especificamente na Seção 4.4.3.

\subsubsection{O Elemento Switch}

O elemento switch permite a um autor especificar um conjunto de elementos alternativos a partir dos quais apenas um elemento aceitável deve ser escolhido. Um elemento é considerado aceitável se o mesmo for um elemento SMU, se seu tipo de mídia associada puder ser 
decodificado, e se todos os seus atributos de teste (ver Seção 4.4.3) forem avaliados como "verdadeiros".

Quando um switch é usado, um elemento é escolhido da seguinte forma: o Player avalia os elementos na ordem em que eles ocorrem dentro do switch. O primeiro elemento aceitável é selecionado em detrimento de todos os outros elementos dentro do switch (inclusive aqueles que ainda não tiverem sido avaliados).

Assim, é importante que os autores sigam uma ordem de prioridade, colocando dentro do switch primeiro as opções mais desejáveis e por último as menos desejáveis. Além disso, deve-se também colocar uma alternativa que nunca falhe como última opção, para que se evite que nenhuma das opções seja contemplada (a menos que isto seja explicitamente desejado). A Seção 4.4.4 apresenta um exemplo de documento SMIL que usa o elemento switch.

\subsubsection{Atributos de Teste}

A linguagem SMIL define uma lista de atributos de teste que podem ser usados em conjunto com qualquer elemento de sincronização e têm a função de testar as capacidades e configurações de um sistema. Quando um desses atributos é avaliado como "falso", o elemento associado a ele é ignorado.

A avaliação de boa parte dos atributos de teste está ligada às preferências do usuário, que podem ser ajustadas através de uma caixa de diálogo provida pelo apresentador SMIL. Os atributos de teste mais relevantes definidos na versão 1.0 da linguagem SMIL são abordados a seguir.

- System-bitrate: Este atributo especifica uma banda passante média, em bits por segundo, necessária para que o elemento associado ao atributo seja apresentado. Este atributo é avaliado como "verdadeiro" se a banda passante disponível para o sistema for maior ou igual à do atributo e "falso" se ela for menor. Usando o system-bitrate é possível, por exemplo, disponibilizar duas versōes de um mesmo vídeo. A primeira, de mais alta resolução, é direcionada para os usuários que possuem conexões rápidas e a segunda, de mais baixa resolução, é direcionada para usuários que possuem conexões lentas. 
- System-language: $\mathrm{O}$ valor desse atributo pode ser qualquer idioma relacionado no documento RFC 1766 [Alv95]. O atributo é avaliado como "verdadeiro" se indicar um idioma que conste nas "preferências do usuário". Assim, é possível disponibilizar um texto ou um áudio em diversos idiomas, especializando o público alvo de um conteúdo de mídia.

- System-captions: Atributo usado para permitir o uso de um texto redundante equivalente a um áudio. Este atributo tem como função permitir que portadores de deficiência auditiva possam utilizar sistemas que fazem uso de mensagens de áudio. $O$ atributo é avaliado como "verdadeiro" caso o usuário tenha optado, nas "preferências do usuário", por ver as mensagens redundantes e, como "falso", caso contrário.

\subsubsection{Exemplos de Documentos SMIL}

Um arquivo SMIL pode ser gerado em qualquer editor ou processador de texto e então salvo como documento texto e com a extensão ".smi”. A seguir são mostrados alguns exemplos de documentos SML que usam os elementos abordados nas seções anteriores.

A Figura 4.8 mostra um exemplo de documento SMI no qual dois objetos de áudio são apresentados em seqüência, pois estão contidos dentro de um elemento seq. Já a Figura 4.9, mostra um exemplo do uso do elemento par, que serve para apresentar mídias paralelamente.

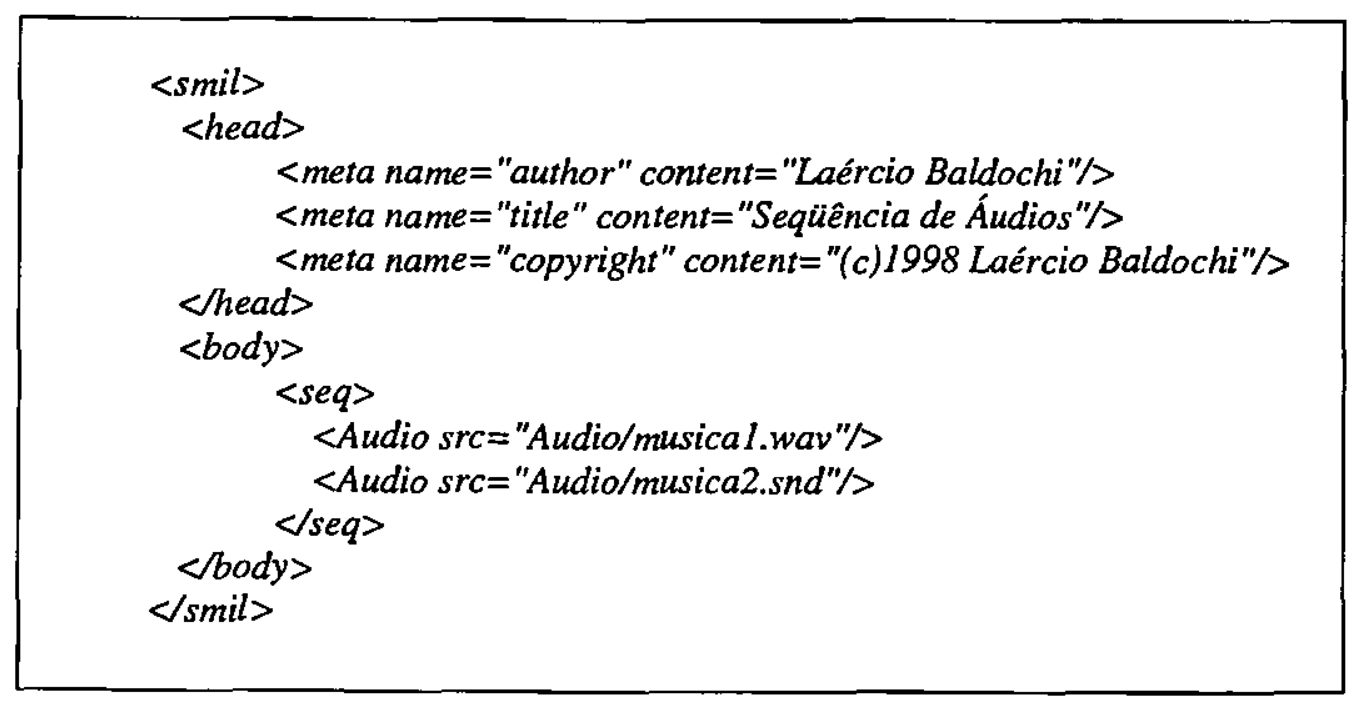

Figura 4.8 - Uso do elemento seq em um documento SMIL. 


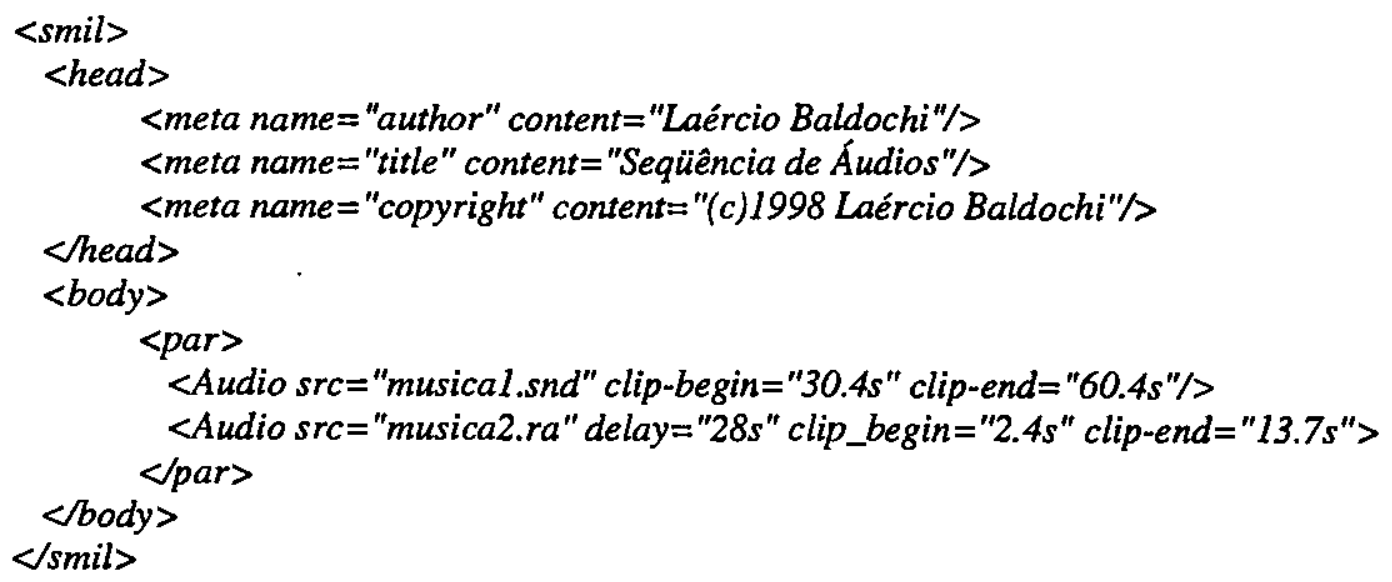

Figura 4.9 - Uso do elemento par em um documento SMIL.

O exemplo mostrado na Figura 4.9 traz uma série de atributos que modificam os elementos de mídia e de sincronização existentes no documento. Os atributos de temporização alteram o funcionamento do elemento par de forma a fazer com que os clips de vídeo comecem em tempos diferentes. O primeiro clip inicia imediatamente, mas começa a tocar na posição 30,4 segundos a partir do início de sua linha de tempo. Como este clip termina na posição 60,4 segundos de sua linha de tempo, o mesmo será tocado por exatamente 30 segundos. O segundo clip é atrasado por 28 segundos, o que significa que este irá se sobrepor ao primeiro por 2 segundos. Ele começa na posição 2,4 e termina na posição 13,7 segundos, sendo, portanto, apresentado por 11,3 segundos. O tempo total de apresentação desse grupo de elementos de mídia será 30 segundos do primeiro clip, mais 13,7 segundos do segundo clip, menos 2 segundos gastos na sobreposição dos dois clips, o que resulta em 39,3 segundos.

O terceiro exemplo, mostrado na Figura 4.10, apresenta o uso de elementos par e seq intercalados. 


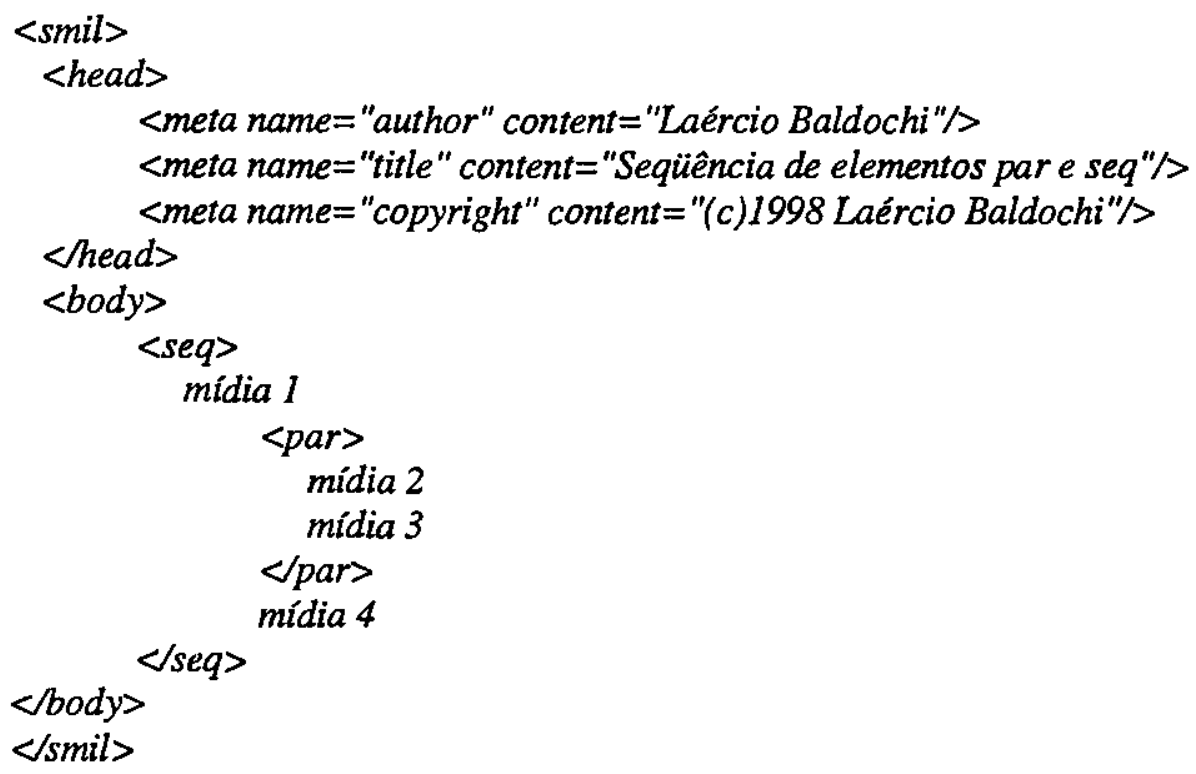

Figura 4.10 - Uso de elementos par e seq intercalados em um documento SMIL.

A funcionalidade provida pela intercalação de par e seq no documento da Figura 4.10 é a seguinte: inicialmente a mídia 1 é apresentada. Quando a mídia 1 termina, as mídias 2 e 3 são apresentadas simultaneamente. Quando ambas terminam, a mídia 4 é apresentada.

Finalmente, o documento da Figura 4.11 mostra o uso do elemento switch e dos atributos de teste. Este documento oferece três possibilidades para a execução de uma apresentação multimídia. A escolha do tipo da apresentação está relacionada com a velocidade da conexão disponível pelo usuário. Para um usuário que tenha uma conexão do tipo "dual ISDN" ou mais rápida, a avaliação do primeiro atributo de teste será verdadeira, sendo que as demais não serão sequer analisadas. Para um usuário que tenha uma conexão do tipo "single ISDN", a avaliação do primeiro atributo será falsa e a do segundo verdadeira, sendo a terceira não avaliada. Para usuários conectados via modem, a $28.800 \mathrm{Kbps}$, apenas o terceiro atributo será avaliado como verdadeiro. 


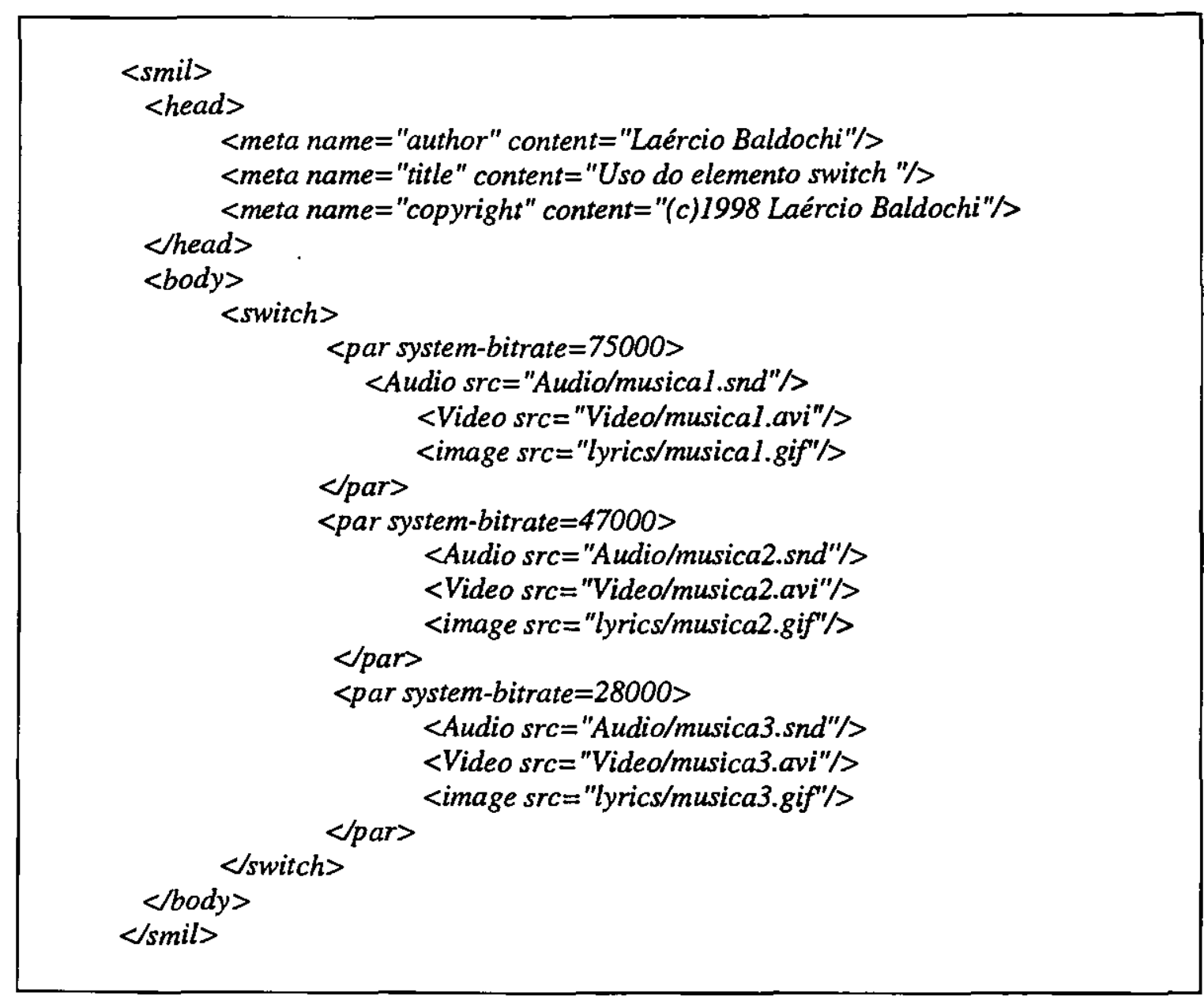

Figura 4.11 - Uso do elemento switch em um documento SMIL.

\subsection{Intersecção entre os padrões MHEG e HyTime e a recomendação SMIL}

Os padrões MHEG e HyTime e a recomentadação SMLL possuem diversas similaridades, que, no entanto, não são aparentes à primeira vista. Baseando-se em suas definições, tem-se que o MHEG está direcionado para a definição da estrutura e regras de apresentação de objetos multimídia; o HyTime está direcionado para a definição da estrutura de hiperdocumentos; e o SMLL está direcionado para a definição de apresentações multimídia sincronizadas no contexto da WWW. 
No entanto, a partir de uma análise mais aprofundada de cada um desses padrões, percebe-se uma série de coincidências. O HyTime, por exemplo, permite a inclusão de informação multimídia em seus hiperdocumentos. Objetos MHEG, por sua vez, podem incluir especificação de ligações entre objetos. Finalmente, o SMIL permite tanto a definição da estrutura e regras de apresentação de objetos multimídia, como também a possibilidade de interligar estes objetos através do uso de hiperligações.

Comparando-se especificamente o HyTime e o MHEG, vê-se que ambos apresentam-se como padrões que permitem especificar elementos comuns de modo diferente, sendo necessário um engine apropriado para a apresentação de cada um deles. Vale observar que um dos padrões aceitos para especificação de objetos MHEG é o HyTime, o que significa que MHEG suporta HyTime. Por outro lado, o HyTime também permite a especificação de outros padrões para definição de seus elementos. Isso significa que o MHEG pode ser especificado como sendo o padrão de um elemento HyTime [Pim95].

Uma outra possibilidade de intersecção entre estes dois padrões está no uso cooperativo de ambos. Segundo Rutledge et al. [Rut97], os padrōes HyTime e MHEG (mais particularmente a parte 5 deste padrão) podem desempenhar papéis complementares em ambientes hipermídia abertos. Um exemplo de cooperação entre eles seria o uso do padrão MHEG-5 para a codificação de apresentações de documentos HyTime, como discutido anteriormente por Pimentel [Pim95].

O SMIL, por sua vez, busca oferecer os recursos providos pelos padrões MHEG e HyTime para o ambiente da WWW. A fim de se firmar neste ambiente, o SMIL se espelha no HTML, buscando conquistar adeptos pela sua simplicidade [Bro98]. Dentre as várias semelhanças entre o HyTime e o SMIL está o fato de ambos serem baseados em padrões anteriores, a saber SGML e XML, respectivamente. Isto explica o fato do HyTime ser mais poderoso, e também mais complexo, que o SMIL, uma vez que o XML é uma simplificação do SGML.

Certamente a maior vantagem do SMIL sobre os dois padrões apresentados neste capítulo, principalmente o HyTime, está no fato deste se basear no $X M L$, que já é considerado um padrão aceito no contexto da WWW (browsers como o Internet Explorer 4.0 suportam XML). A importância da WWW no contexto das aplicações hipermídia leva a crer que o SMIL tem tudo 
para se tornar um padrão largamente utilizado para a especificação de apresentações multimídia dentro do contexto da World Wide Web.

Entretanto, vale frisar que estes padrões são complementares, como demonstram as propostas recentes para suportar aplicações multimídia no contexto da WWW discutidas por Rutledge et al. [Rut98] e Price [Pri98].

\subsection{Considerações Finais}

Neste capítulo foram apresentados dois padrões (MHEG e HyTime) e uma recomendação do W3C (SMIL) usados na especificação e no intercâmbio de hiperdocumentos e objetos multimídia. Dos três, maior ênfase foi dada ao padrão MHEG-5, utilizado como base para o desenvolvimento deste trabalho.

Os sistemas hipermídia estão em constante evolução, demandando que cada vez mais os padrões permitam a especificação de aplicações com mais e mais recursos. Essa necessidade faz surgir novos padrōes ou recomendações do W3C, como é o caso do XML e do SMIL, que vêm para suprir a falta de linguagens capazes de especificar relações de sincronização multimídia no ambiente da WWW.

Mais que simplesmente apresentar características dos padrões de intercâmbio multimídia, este capítulo preocupou-se em compará-los, mostrando sobretudo a relação do SMIL com padrões já existentes como é o caso do MHEG e do HyTime. 
"A grandeza nāo consite em receber honras, mas em merecê-las."

Aristóteles

\subsection{Considerações Iniciais}

A evolução que tem ocorrido nos últimos anos nas redes de computadores e nas plataformas de sistemas distribuídos direcionaram as pesquisas na área de multimídia para soluções naturalmente distribuídas. As soluções atuais acomodam dados e aplicações multimídia em uma mesma plataforma, limitando-os à capacidade do meio de armazenamento e ao desemplenho do hardware que os hospeda. As soluções distribuídas, por outro lado, mantêm os dados espalhados pela rede, utilizando-os no momento em que a aplicação os solicitar. Isto amplia significativamente a flexibilização no desenvolvimento de aplicações e de transferência de documentos multimídia [Tre95].

No entanto, a implementação de tais soluções depende do avanço da tecnologia disponível em áreas como compressão de dados, tráfego de dados para transferência de mídia contínua e em tempo real (vídeo e animação, por exemplo), armazenamento e recuperação de dados, e sincronização multimídia. O objetivo principal do Projeto $\mathrm{SMmD}$ consiste em propor soluções a fim de superar as limitações existentes nestas áreas, contribuindo, assim, para o desenvolvimento de aplicações multimídia distribuídas.

O projeto SMmD [Tei94] propõe constituir-se em uma estrutura de middleware (componentes de software do sistema situados entre sistemas operacionais genéricos e aplicações), oferecendo um conjunto de serviços para facilitar a construção de aplicações multimídia interativas e tratar de questões de sincronização e manipulação de mídia contínua em ambiente distribuído e heterogêneo. 
O projeto acompanha a tendência de desenvolvimento de sistemas abertos multimídia em ambientes distribuídos, que propicia a construção de aplicações de características diferentes das contempladas pelas técnicas atuais [Tei98]. Assim, aplicações como trabalho cooperativo com suporte computadorizado e sistemas abertos hipermídia, que permitem a composição de documentos a partir de objetos multimídia (compostos por elementos de diversas mídias e armazenados em bases de dados distribuídas), tornam-se viáveis.

Este capítulo está organizado da seguinte forma: a Seção 5.2 apresenta o Ambiente SMmD, descrevendo seus principais módulos e como estes módulos se inter-relacionam; a Seção 5.3 descreve em detalhes a máquina MHEG-5 desenvolvida para o Ambiente SMmD; por fim, a Seção 5.4 conclui este capítulo fazendo algumas consideraçōes a respeito da importância do Ambiente SMmD no contexto da apresentação multimídia em ambientes distribuídos e heterogêneos.

\subsection{O Ambiente SMmD}

A estrutura de middleware do projeto SMmD, chamada de ASMmD [Tei98] - Ambiente $\mathrm{SMmD}$ - constitui-se de um conjunto de softwares, devidamente integrados, com o objetivo de propiciar suporte ao desenvolvimento e execução de aplicações multimídia distribuídas que manipulam e realizam o intercâmbio de objetos em conformidade com o padrão MHEG-5.

A arquitetura do Ambiente SMmD é mostrada na Figura 5.1. Esta arquitetura é baseada em modelos de arquitetura propostos pelo DAVIC [DAV96] — Digital Audio Visual Council para dispositivos do tipo set top boxes, a serem usados pela TV interativa e por aplicações de vídeo sob demanda. Os módulos principais desta arquitetura são discutidos a seguir.

O Módulo de Apresentação e Sincronização, MAS, é o módulo responsável pela apresentação e pela sincronização espacial e temporal, intramídia e intermídia, das mídias que compõem um objeto multimídia. Além disso, é responsável também pelo controle das interfaces com o usuário e com as aplicações. 


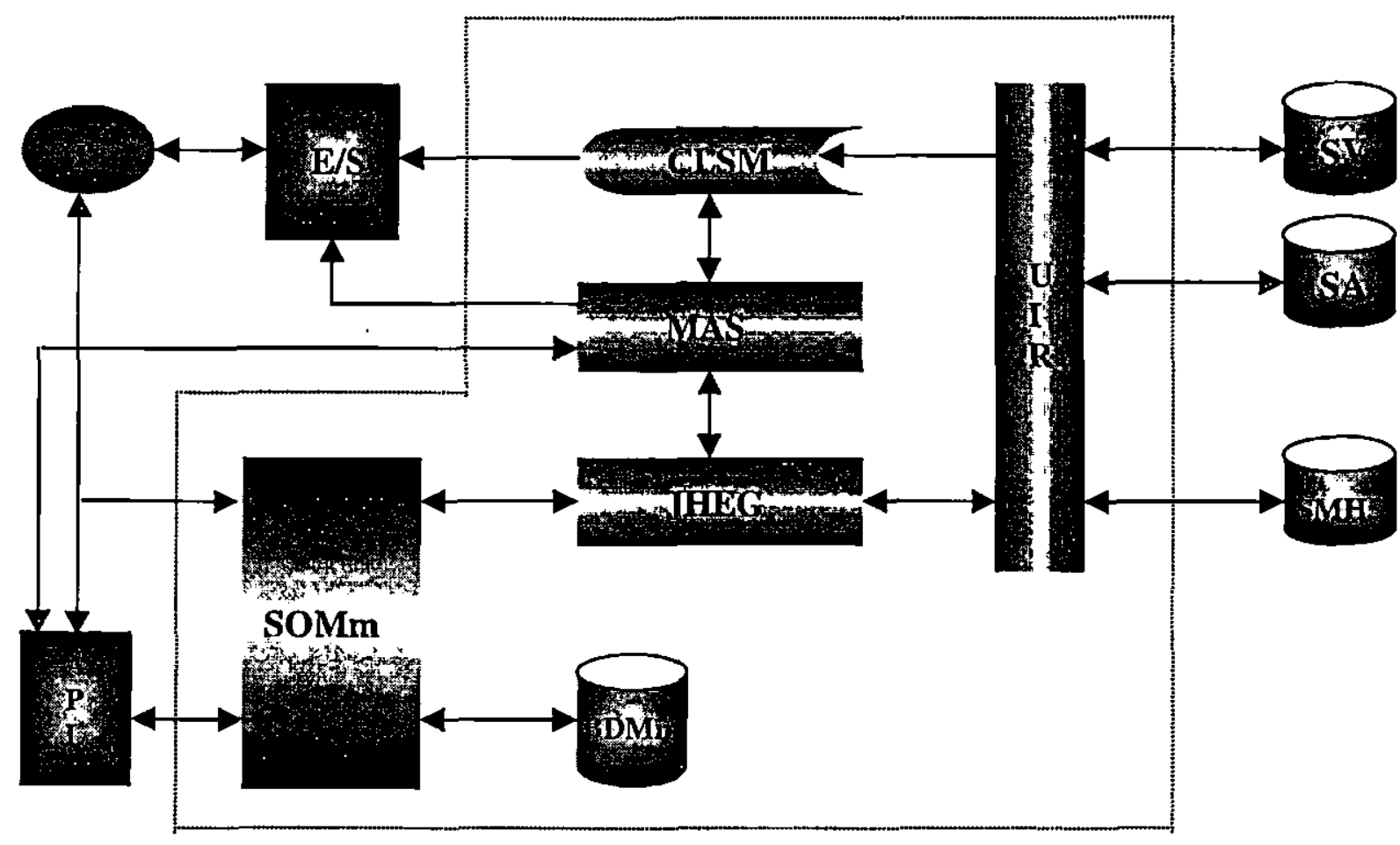

APL: Aplicações

BDMm : Base de Dados Multimídia

CLSM: Componentes Locais de Servidores de Mídia

E/S: Dispositivos de Entrada e Saída

JHEG: Java MHEG-5 Engine
MAS: Módulo de Apresentação e Sincronização SOMm: Servidor de Objetos Multimídia

U: Usuários

UIR: Unidade de Interface de Rede

SV: Servidor Remoto de Vídeo

SA: Servidor Remoto de Áudio

SMH5: Servidor MHEG-5 Remoto

Figura 5.I - O Ambiemte SMmD [Tei98]

De forma geral, pode-se dizer que o MAS serve de interface entre as aplicações e os demais módulos do Ambiente SMmD. Assim, quando uma aplicação solicita ao MAS a apresentação de um objeto de mídia, este passa uma referência ao objeto para o módulo JHEG (Java MHEG-5 Engine), que, por sua vez, carrega o objeto, decodifica sua informação e passa esta informaçāo de volta ao MAS. O MAS, então, apresenta o objeto de acordo com as especificações requeridas pela aplicação. Os componentes de mídia a serem apresentados podem estar incluídos no objeto multimídia em questão ou apenas referenciados. Neste último caso, o MAS deve acionar o 
módulo Componentes Locais de Servidores de Mídia, CLSM, para que este os recupere à partir de servidores remotos. A conexão entre o CLSM e os servidores de mídia remotos é realizada através da Unidade de Interface de Rede, UIR.

O módulo JHEG - Java MHEG-5 Engine — implementa uma máquina MHEG-5 responsável por disponibilizar objetos para processamento e apresentação. Tais objetos podem estar em uma memória cache local, em servidores MHEG-5 remotos ou no módulo Servidor de Objetos Multimídia, SOMm, que é o servidor MHEG-5 local e proprietário do ambiente SMmD.

O módulo SOMm [VS97] [SVF97], implementado com o Sistema Gerenciador de Banco de Dados O2, permite a armazenagem e a recuperação de objetos MHEG-5. A informação fornecida no momento da criação de um novo objeto é armazenada em um banco de dados obedecendo a estrutura de classes definida pelo MHEG-5, sob gerenciamento do sistema $\mathrm{O} 2$.

As aplicações usam o módulo SOMm tanto para armazenar novos objetos quanto para recuperar referências a objetos já armazenados. As referências resultantes de uma consulta feita por uma aplicação são passadas para os módulos JHEG e MAS, que realizam a recuperação, o processamento e a apresentação do objeto correspondente.

Um autor pode interagir diretamente com o módulo SOMm usando uma ferramenta de autoria para objetos MHEG-5 chamada SMART [SV98]. Esta ferramenta está totalmente integrada ao módulo SOMm, e, como ele, foi também desenvolvida em $\mathrm{O} 2$.

Finalmente, o ASMmD conta ainda com dois módulos de servidores de mídia remotos: o Servidor de Áudio (SA) e o Servidor de Vídeo (SV). O primeiro foi desenvolvido sob a plataforma distribuída ANSAware e o segundo usa PVM como mecanismo de comunicação. A interface desses servidores com o MAS é feita através do módulo CLSM. Maiores informaçőes a respeito dos módulos SA e SV podem ser obtidos, respectivamente, em [FT97] e [AT96].

Entre todos os módulos do Ambiente $\mathrm{SMmD}$, dois são mais relevantes do ponto de vista desta dissertação. O primeiro é o módulo JHEG, descrito na seção a seguir. O outro, é o módulo MAS, implementado a partir do JHEG e detalhadamente descrito no Capítulo 7. 


\subsection{A Máquina MHEG do projeto SMmD}

O primeiro passo na geração do middleware proposto pelo projeto SMmD foi a implementação de uma máquina MHEG-5, conhecida como JHEG - Java MHEG-5 Engine [Abr97] — cujo modelo é apresentado na Figura 5.2 e descrito a seguir.

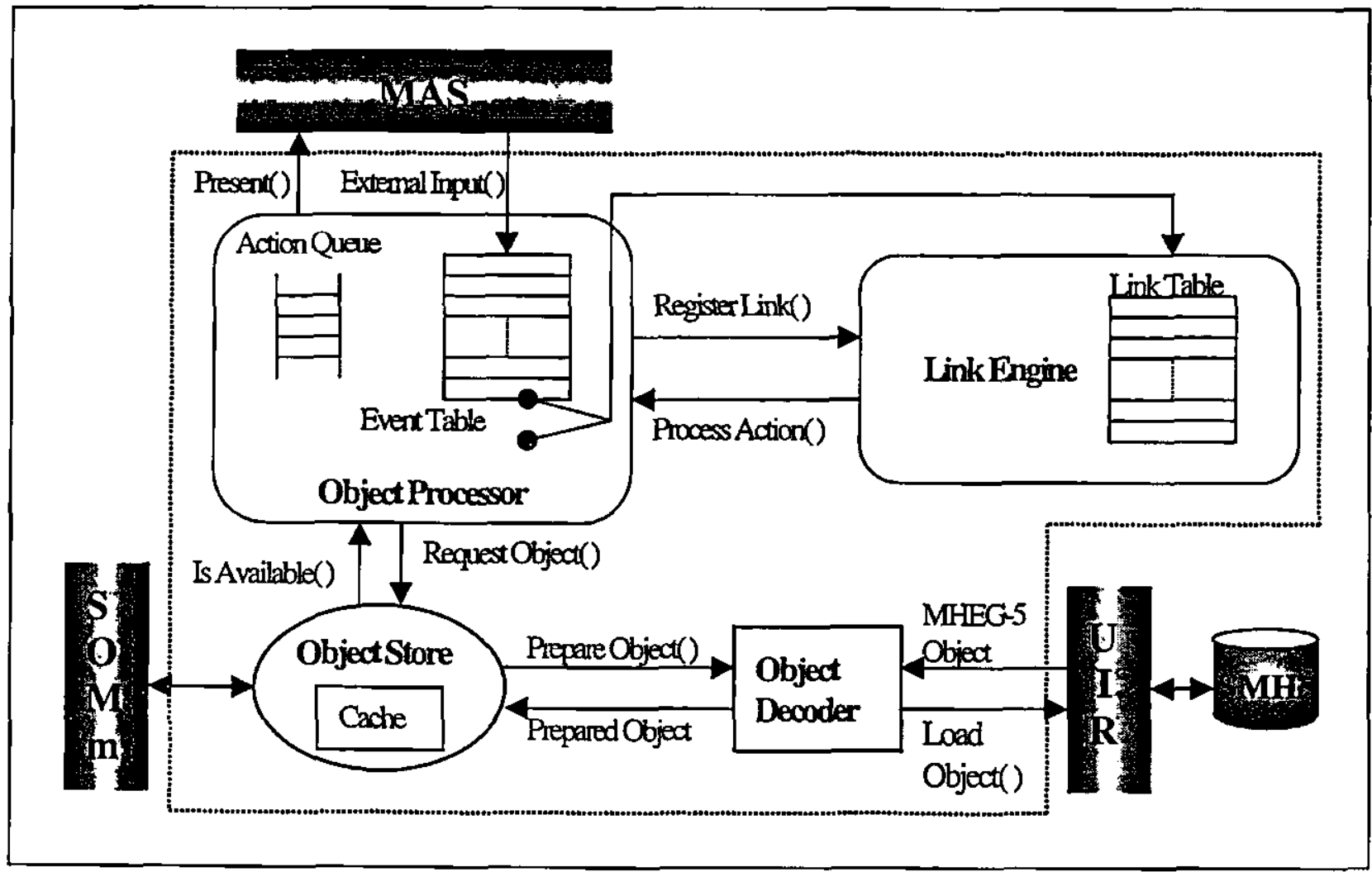

Figura 5.2 - Modelo da máquina MHEG-5 do projeto SMmD [Tei98]

O Object Processor é o módulo responsável pela interpretação efetiva de objetos $M H E G-5$ e pela execução de ações. Quando objetos link devem ser ativados, o Object Processor os registra no módulo Link Engine, onde é mantida uma tabela de mapeamento de LinkConditions em LinkEffects. O Object Store fornece objetos preparados ao Object Processor, e o Object Decoder cuida da decodificação e preparação de objetos MHEG-5. 
O engine MHEG-5 é átivado por uma aplicação qualquer que indica a identificação e a localização do primeiro objeto aplicação ou cena a ser executado. Uma vez que o Object Processor tem a posse do objeto a ser processado, ele requisita ao Object Store o objeto já preparado. O Object Store mantem um cache com objetos scene preparados a priori, com o objetivo de minimizar o atraso no tempo de acesso. Estes objetos podem ter sido preparados antecipadamente, ou então, terem sido preparados em momento anterior e guardados no cache, por, eventualmente, apresentarem alta probabilidade de voltarem a ser requisitados dentro de um intervalo de tempo curto. Se o Object Store não dispuser do objeto requerido, ele invoca o Object Decoder ou o módulo Servidor de Objetos Multimídia (SOMm) para que um deles obtenha o objeto, o decodifique e o prepare.

Com base no tipo do objeto a ser processado, o Object Processor identifica os atributos a serem consultados na estrutura resultante da preparação do objeto, e as medidas iniciais implícitas que devem ser tomadas. Se estiver processando um objeto application ou scene, por exemplo, o Object Processor inicia a execução do objeto Action especificado no atributo OnStartUp. As ações elementares são colocadas todas em uma fila e processadas ordenadamente. Os objetos link encontrados pelo Object Processor em objetos Scene ou Application são registrados na Link Table.

Alguns eventos podem ocorrer como consequiência das atividades de processamento do Object Processor (eventos síncronos) ou gerados por processos assíncronos à máquina MHEG-5, como manifestações do usuário, vencimento de temporizadores, etc. No caso dos eventos externos (assíncronos), as ocorrências são reportadas ao Object Processor através de primitivas do tipo ExternalInput( ), traduzidas em eventos reconhecidos pelo padrão e, assim como eventos síncronos, anunciadas ao Link Engine.

Ao receber a notificação de ocorrência de algum evento, o Link Engine consulta os Links registrados para determinar se e quais devem ser disparados. Finalmente, quando um link é disparado, o Link Engine utiliza a primitiva ProcessAction( ) para informar ao Object Processor quais objetos Action devem ser processados. 


\subsection{Considerações Finais}

Existem atualmente no mercado vários produtos que suportam aplicações multimídia interativas tratando de questões de sincronismo e manipulação de mídia contínua. Entretanto, esses produtos são adequados apenas para sistemas stand-alone. O que diferencia a arquitetura $S M m D$ desses produtos é seu enfoque ao tratamento dessas questões em ambiente distribuído e heterogêneo.

No sentido de desenvolver a estrutura de middleware que possibilite o intercâmbio de objetos multimídia em sistemas distribuídos e heterogêneos, o primeiro passo foi especificar e implementar uma máquina MHEG-5, chamada JHEG, responsável pela codificação, decodificação e execução de objetos MHEG-5. Todos os demais módulos do projeto $S M m D$ deverão interagir, direta ou indiretamente, com o JHEG a fim de proporcionar a funcionalidade adequada à estrutura de middleware como um todo. Dessa forma, o módulo apresentador, por exemplo, recebe do JHEG objetos e/ou referências a objetos que devem ser apresentados, e passa a este módulo eventuais interações do usuário com esses objetos. A interação do módulo apresentador com o JHEG será detalhadamente especificada no Capítulo 7. 
"Ao ver uma luz no fim do túnel, certifique-se que nāo é o trem."

Anônimo

\subsection{Considerações Iniciais}

A implementação do Módulo de Apresentação e Sincronização (MAS), descrito em detalhes no Capítulo 7, foi precedida de um trabalho de pesquisa que visou determinar as tarefas mais críticas em termos de implementação e a melhor forma de implementá-las.

Este trabalho de pesquisa teve como principal função determinar a ferramenta a ser utilizada no desenvolvimento do MAS. A ferramenta escolhida foi a linguagem Java, estendida pela API Java Media Framework Player (JMF Player), abordada em detalhes no Apêndice B.

Durante esta fase do trabalho, inúmeros testes foram feitos com o objetivo de verificar se a ferramenta escolhida era capaz de apresentar mídias, sobretudo mídias contínuas, obedecendo relações de sincronização intra e intermídia. Entre eles está a implementação do applet SyncEvent, a partir do qual foi desenvolvido o Módulo de Apresentação e Sincronização. Este capítulo relata o trabalho de pesquisa que levou à escolha da ferramenta adotada, enfatizando a implementação do applet SyncEvent, embrião do Módulo de Apresentação e Sincronização.

O assunto a ser abordado neste capítulo está estruturado da seguinte forma: a Seção 6.2 contextualiza o início do trabalho de desenvolvimento do MAS, mostrando a necessidade de integração deste com o módulo JHEG; a Seção 6.3 aborda a implementação do applet SyncEvent, descrevendo o processo de desenvolvimento de suas duas versões; a Seção 6.4 demonstra a viabilidade do uso do applet SyncEvent como apresentador, no contexto da WWW, de relações temporais especificadas através de padrões como HyTime e MHEG; a Seção 6.5 demonstra a relevância do mecanismo de apresentação proposto tendo como argumento o surgimento da 
linguagem SMIL; finalmente, a Seção 6.6 faz algumas considerações sobre a importância do applet SyncEvent no contex to dessa dissertação.

\subsection{Contexto: o Módulo JHEG e a Linguagem Java}

A implementação do módulo JHEG - Java MHEG-5 Engine - iniciou-se cerca de um ano antes da implementação do MAS. Os pesquisadores envolvidos na implementação do JHEG elegeram Java como ferramenta para desenvolvimento deste módulo. Tal escolha se deu, principalmente, devido à portabilidade inerente às aplicações Java, uma vez que era desejável que a máquina MHEG pudesse ser executada no maior número possível de plataformas.

Diante desse fato, e levando em consideração a forte interação entre o MAS e o JHEG, a ferramenta mais indicada para a implementação do MAS seria a linguagem Java. O uso da linguagem Java na implementação desses dois módulos, além de trazer a vantagem óbvia de facilitar a comunicação de ambos, era também interessante no nível global do projeto SMmD, pois a adoção de uma mesma ferramenta estaria colaborando para a unicidade do projeto.

No entanto, nesta época a linguagem Java praticamente não dispunha de nenhum mecanismo que facilitasse a manipulação de mídias contínuas, o que a tornava pouco apropriada para a implementação do MAS. A seção a seguir relata as primeiras implementações de apresentadores multimídia feitas em Java e o trabalho realizado na tentativa de superar as limitações da linguagem Java no tocante à manipulação de mídias contínuas.

\subsection{Implementação das Relações Temporais de Allen}

Com o intuito de se verificar a viabilidade de utilização da linguagem Java na implementação de um apresentador multimídia, o primeiro passo foi a implementação de um applet capaz de apresentar duas mídias contínuas obedecendo as 13 relações temporais binárias propostas por Allen, ilustradas na Figura 3.6.

O primeiro problema para o desenvolvimento deste applet surgiu antes mesmo do início de sua implementaçāo. Este problema estava relacionado com a ausência de suporte para manipulação 
de mídias contínuas na linguagem Java, uma vez que, naquela época, o ambiente provido pela Java Virtual Machine possibilitava apenas a apresentação de áudio, sem, no entanto, prover nenhuma facilidade para o controle de execução do mesmo. Isto significava que, apesar de ser possível disparar um áudio em um dado momento, não era possível manter o controle sobre a apresentação deste áudio, ou seja, não era possível fazer operações como pause, resume, fastforward e backward com o mesmo.

Uma forma de se superar as limitações da linguagem Java proposta naquela época foi a implementação de código nativo, em linguagem $\mathrm{C}$ ou $\mathrm{C}+$, responsável por prover a implementação das rotinas necessárias à apresentação de mídias contínuas. Seria necessário então, disponibilizar tais rotinas em uma biblioteca e acioná-las a partir de programas implementados em Java.

Esta idéia, no entanto, não parecia ser a mais indicada no contexto do trabalho. Isto porque, além das dificuldades inerentes à programação em baixo nível, as rotinas desenvolvidas para manipulação de mídias contínuas deveriam ser implementadas para cada plataforma na qual se desejasse disponibilizar o apresentador.

Apesar das dificuldades inerentes à implementação de código nativo, esta parecia ser a única solução para permitir a apresentação de mídias contínuas pelo MAS. No entanto, antes de realizar esta tarefa era necessário verificar se a linguagem Java oferecia suporte para a apresentação simultânea de mídias, ou seja, era necessário testar se sua característica multithreading era mesmo adequada à apresentação multimídia. Para tanto foi implementada a primeira versão do applet SyncEvent, descrita a seguir.

\subsubsection{A Primeira Versão do Applet SyncEvent}

A especificação inicial do applet SyncEvent tinha como objetivo torná-lo capaz de apresentar duas mídias contínuas (áudio e vídeo) de forma que as mesmas pudessem ser apresentadas de acordo com as 13 relações temporais binárias de Allen. No entanto, a primeira versão do applet SyncEvent acabou se tornando um produto bem mais modesto, devido às seguintes limitações impostas pelo ambiente de desenvolvimento Java (JDK - Java Development Kit) usado: 
- Não era possível apresentar vídeo, conforme explicado na seção anterior;

- Não se tinha controle sobre a apresentação de um áudio. Isto gerava uma série de implicações, das quais a mais importante era a ausência de notificação do término da apresentação do áudio, impossibilitando a implementação da relação binária $A$ after $B$ (considerando-se que a mídia B seja um áudio).

A fim de remediar estes problemas e testar as características multithreading da linguagem Java na tarefa de apresentação multimídia, implementou-se a primeira versão do applet SyncEvent usando-se uma animação no lugar do vídeo e um parâmetro adicional na chamada do applet, que informava a duração do stream de áudio, de forma a possibilitar a implementação da relação binária $A$ after $B$.

A animação consistia de um texto, cujas porçōes eram mostradas na tela através de um efeito de rolagem da mesma. Assim, cada linha do texto surgia na parte inferior da tela e rolava até a parte superior, dando a idéia de movimento. O áudio consistia da leitura deste texto de forma que, quando ambos eram apresentados de acordo com a relação temporal $A$ equals $B$, 0 usuário poderia acompanhar o áudio lendo a mensagem na tela.

A implementação da primeira versão do applet SyncEvent foi feita utilizando-se duas threads explícitas, criadas para manipular a recuperação e a apresentação de cada uma das mídias de forma independente e paralela. Nesta versão, a implementação das relações temporais entre as mídias é feita através de comunicação entre as duas threads, e as sincronizações ocorrem através da suspensão temporária de uma delas.

Assim, para se apresentar as mídias segundo a relação temporal $A$ after $B$, onde A é o texto e B é o áudio, suspende-se inicialmente a thread que manipula o áudio (colocando-a para "dormir") e inicia-se a thread que controla a apresentação do texto. Ao concluir sua apresentação, a thread envolvida na apresentação do texto "acorda" a thread que estava dormindo e esta realiza a apresentação do áudio. 
A primeira versão do applet SyncEvent foi usada para comprovar a proposta de especificação das treze relações temporais binárias de Allen usando-se HyTime [Pim97a] [Pim97b], de forma a possibilitar que uma ou mais dessas especificações possam ser incluídas em um documento HTML, produzindo um documento HTML estendido. De acordo com a proposta, o documento HTML estendido serve de entrada para um tradutor capaz de converter especificações HyTime em ativações ao applet SyncEvent, gerando um segundo arquivo HTML que contem tais ativações no lugar do código HyTime.

$\mathrm{O}$ arquivo HTML gerado pelo tradutor é então apresentado por um navegador que ofereça suporte à apresentação de applets Java, possibilitando que o applet SyncEvent apresente as mídias de acordo com as especificações HyTime contidas no arquivo HTML original.

Além de ter sido uma contribuição importante para a comprovação da proposta do artigo descrito acima, a primeira versão do applet SyncEvent também serviu para demonstrar que a linguagem Java, graças à sua característica multithreading, era apropriada para a implementação de apresentadores multimídia. Restava, entretanto, o problema da ausência de suporte à apresentação de mídias contínuas.

Felizmente, nesta época, foi disponibilizada a primeira versão beta da API JMF Player. Esta API, estende a linguagem Java provendo não só facilidades para a apresentação de mídias contínuas, como também formas de se expressar relações de temporização e sincronização entre essas mídias.

Com o surgimento desta API foi possível reescrever o applet SyncEvent, desta vez possibilitando que qualquer par de mídias contínuas (áudio e vídeo, vídeo e vídeo, etc.) fosse apresentado de acordo com as relações temporais binárias propostas por Allen. A seção a seguir descreve a implementação da segunda versão do applet SyncEvent. 


\subsubsection{A Segunda Versão do Applet SyncEvent}

As facilidades providas pela API JMF Player tornaram possível a implementação de um applet muito mais funcional, atendendo todos os requisitos que não puderam ser satisfeitos na primeira versão do SyncEvent.

Nesta implementação, cada uma das mídias foi associada a um JMF Player, que é um objeto que processa um fluxo de dados à medida que o tempo transcorre, apresentando-os em um instante preciso (o Apêndice B aborda com detalhes o funcionamento dos Players no contexto da API JMF). Esta API fornece uma série de facilidades para apresentação sincronizada de Players, permitindo a sincronização de um número arbitrário de Players, e, portanto, de mídias.

No contexto do mecanismo de apresentação multimídia à partir de especificaçōes HyTime apresentado na seção anterior, a segunda versão do applet SyncEvent possibilitou a especificação HyTime de relações de temporização e sincronização entre mídias arbitrárias. Na primeira versão do applet as mídias deviam ser, obrigatoriamente, um áudio e um texto. $\mathrm{Na}$ segunda versão passou a ser possível, através de pequenas alterações no código fonte do applet, o uso de um par qualquer de mídias contínuas, tornando o mecanismo proposto no artigo muito mais flexível.

Além disso, graças às facilidades providas pela API JMF Player, foi possível estender a funcionalidade do applet permitindo que ele expresse não somente as relações temporais propostas por Allen como também o modelo avançado de sincronização baseado em intervalos proposto por Wahl e Rothermel [WR94], mostrado na Figura 3.7.

A Figura 6.1 mostra um exemplo de código HTML escrito para ativar o applet SyncEvent. Este código, gerado a partir do tradutor HyTime/HTML para o caso da relação temporal binária $A$ equals $B$, contém parâmetros que informam ao applet o nome e a localização das mídias a serem apresentadas, bem como parâmetros que especificam o tipo da relação temporal binária a ser usada na apresentação. A seguir, são especificadas as funções de cada um dos parâmetros usados na ativação do applet SyncEvent, para o caso específico do código mostrado na Figura 6.1:

- audiofile e videoFile: indicam a URL dos streams de áudio e vídeo a serem apresentados; 
- startA e startV: indicam posições temporais, a partir de um instante to, nas quais deve se iniciar a apresentação das mídias de áudio e vídeo, respectivamente;

- durA e durV: indicam a duração da apresentação das mídias áudio e vídeo, respectivamente. Se a duração especificada for maior que a duração total da apresentação da respectiva mídia, deve-se apresentar a mesma em looping até que a duração total seja alcançada. Caso contrário, se a duração especificada for menor que a duração total da mídia, deve-se interromper a apresentação quando a mesma alcançar o tempo indicado pelo parâmetro. Quando se especifica duração igual a zero significa que a mídia deve ser totalmente apresentada uma única vez. Esses parâmetros são necessários a fim de se implementar as relações temporais avançadas propostas por Wahl e Rothermel.



Figura 6.1 - Código HTML usado na ativaçāo do applet Syncevent.

A Figura 6.2 apresenta um recorte de tela do applet SyncEvent executando a relação temporal binária $A$ equals $B$, onde $A$ é um stream de áudio (count.au) e $B$ é um stream de vídeo (count.avi). As mídias utilizadas implementam um contador que avança uma unidade por segundo. Este exemplo demonstra que o applet implementa fielmente as relações temporais, mantendo a sincronização especificada durante toda a apresentação da mídia. No caso da relação 
$A$ equals $B$, o avanço de uma unidade do contador no vídeo representa o avanço de uma unidade na contagem feita pelo áudio. Assim, quando se vê o número 6 na tela, ouve-se a palavra "seis" sendo pronunciada.

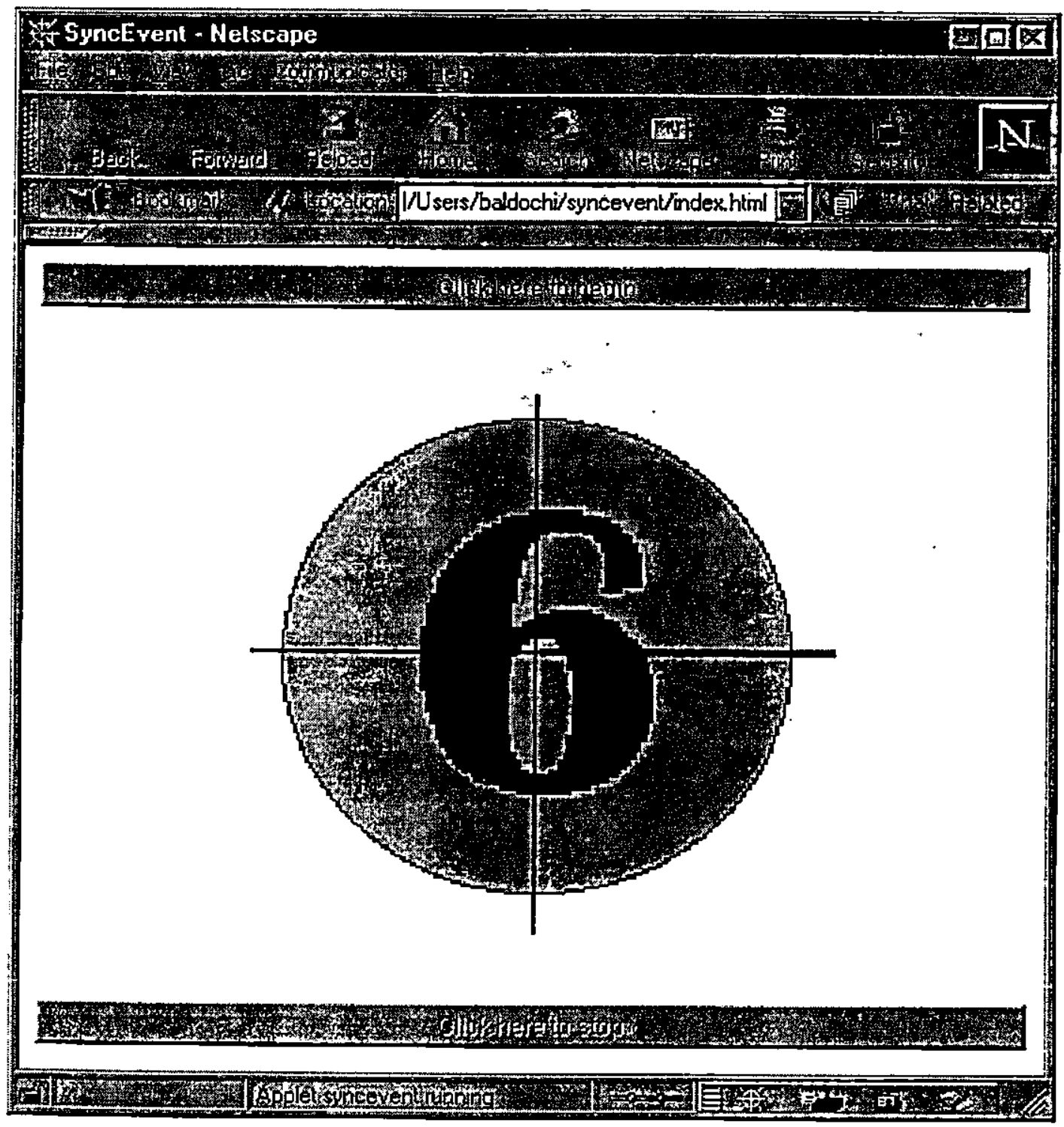

Figura 6.2 - Interface do Applet SyncEvent.

Para o caso da relação $A$ during $B$, especificando um atraso de cinco segundos para a apresentação da mídia $A$, ou seja, start $A=5000$, a exibição dos cinco primeiros números não seria acompanhada de áudio. Quando o vídeo estivesse exibindo o número 6 , seria ouvida a palavra "um", na exibiçāo do número 7 , ouviria-se a palavra "dois" e assim sucessivamente. 


\subsection{O Applet SyncEvent no Contexto dos Padrões HyTime e MHEG}

O applet SyncEvent, como já ressaltado na seção anterior, teve uma importância significativa na validação da proposta de apresentação multimídia sincronizada no ambiente provido pela World Wide Web (WWW) a partir de especificações HyTime. No entanto, mais relevante que a validação desta proposta; é o fato de que este mesmo processo poderia ser realizado utilizando-se outros padrões, como MHEG-5, por exemplo.

Isto significa que, implementando-se um tradutor capaz de transformar aplicações MHEG-5 em ativações ao applet SyncEvent seria possível apresentar tais aplicações no contexto da WWW (se as mesmas envolvessem apenas um objeto áudio e um objeto vídeo, evidentemente). Este fato consistiu em um indicativo de que a implementação do MAS era perfeitamente viável utilizandose a linguagem Java estendida pela API JMF Player. Por outro lado, este mesmo fato mostrou que o padrão MHEG-5 não era apropriado para especificar relações de sincronização, nem mesmo relações simples, como as relações temporais binárias de Allen, uma vez que não possui elementos capazes de expressar que dois objetos devem ser apresentados de forma síncrona. As deficiências do padrão MHEG-5 na especificação de sincronização e suas implicações no desenvolvimento do MAS são abordadas em detalhes no Capítulo 7.

\subsection{O Applet SyncEvent e a Linguagem SMUL}

O surgimento da linguagem SMIL, desenvolvida recentemente pelos pesquisadores do World Wide Web Consortium (W3C) com o intuito de prover maior interatividade ao ambiente estático da WWW, comprova a relevância do applet SyncEvent e do mecanismo de especificação de sincronização e apresentação sincronizada proposta por Pimentel et al. [Pim97a] [Pim97b]. Esta proposta, desenvolvida muito antes do surgimento da linguagem SMIL, implementa a mesma funcionalidade a que se propõe a referida linguagem, e demonstra a viabilidade do uso de padrões como HyTime na especificação de relações de sincronização.

Uma consideração importante no contexto desta dissertação é que um mecanismo de mapeamento semelhante pode ser implementado usando os padrōes MHEG e SMIL com a finalidade de estender o Ambiente SMmD para o contexto da WWW. Este mapeamento 
possibilitaria, através da implementação de um tradutor, que aplicações MHEG-5 fossem apresentadas por navegadores que oferecessem suporte à linguagem SMIL. Usando o mesmo raciocínio, seria também possível implementar um tradutor responsável pela conversão de aplicações SML em aplicaçōes MHEG-5, possibilitando que as mesmas sejam apresentadas pelo Ambiente SMmD. A Figura 6.3 ilustra este mapeamento. Um esquema semelhante, envolvendo os padrőes MHEG-5 e SGML/HyTime, foi recentemente proposto por Rutledge et al. [Rut97].

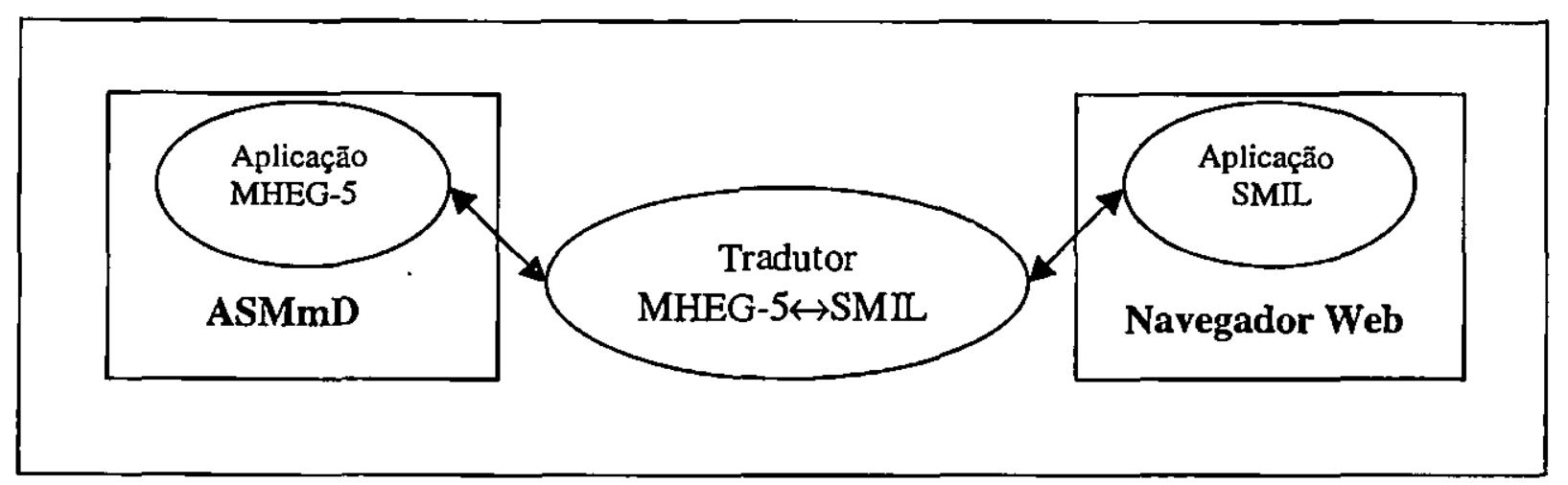

Figura 6.3 - Transformaçāo de aplicaçōes SMIL em aplicações MHEG-5 e vice-versa.

\subsection{Considerações Finais}

A implementação do applet SyncEvent foi fundamental para o desenvolvimento do Módulo de Apresentação e Sincronização, uma vez que demonstrou na prática a viabilidade de se usar a linguagem Java estendida pela API JMF Player na sua implementação.

Além disso, a experiência adquirida neste trabalho de implementação foi muito valiosa, sobretudo no que se relaciona ao funcionamento da API JMF Player. Enfim, pode-se dizer que o applet SyncEvent foi o embrião a partir do qual foi gerado o Módulo de Apresentação e Sincronização. 
“Os pequenos atos que se executam são melhores que todos aqueles grandes que se planejam." George C. Marshall

\subsection{Considerações Iniciais}

Neste capítulo é apresentado o MAS - Módulo de Apresentação e Sincronização — cuja implementação consiste no resultado prático do trabalho de mestrado relatado neste documento. As seções a seguir abordam, detalhadamente, o trabalho de projeto e implementação deste módulo, enfatizando, sobretudo, a implementação de sincronização multimídia, tema central do trabalho desenvolvido.

\subsection{A Arquitetura do Módulo de Apresentação e Sincronização}

O MAS é responsável por três tarefas:

a) analisar arquivos MHEG-5, criando instâncias dos objetos especificados nestes arquivos e passando-as para o módulo Java MHEG-5 Engine (JHEG);

b) apresentar nos dispositivos de saída do usuário objetos MHEG-5, obedecendo eventuais especificações de sincronização;

c) relatar ao JHEG quaisquer interações do usuário com tais objetos.

A Figura 7.1 mostra os principais componentes da arquitetura do MAS. O módulo Analisador Sintático MHEG-5 (ASMH5) é o módulo responsável pela realização da tarefa (a). Os módulos Gerenciador de Apresentações Multimídia (GAM), Apresentador de Mídia Estática (AME), Apresentador de Mídia Contínua (AMC) e Apresentador de Mídias Sincronizadas (AMS) foram desenvolvidos com a finalidade de prover a funcionalidade exigida pela tarefa $(b)$. O módulo Interface Usuário-JHEG (IUJ), por sua vez, foi desenvolvido para prover a funcionalidade exigida pela tarefa $(c)$. 


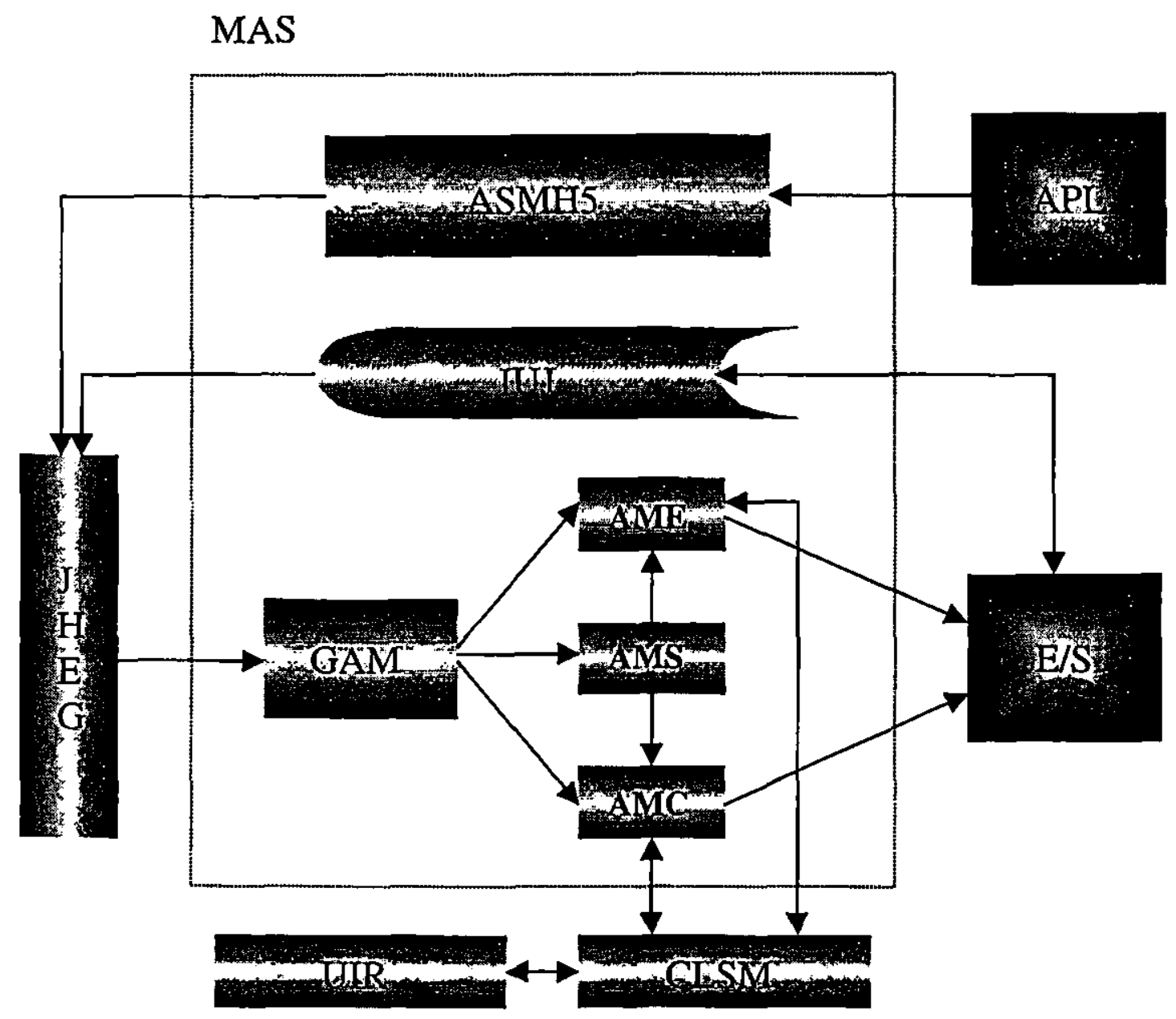

AMC: Apresentador de Mídia Contínua AME: Apresentador de Mídia Estática AMS: Apresentador de Mídias Sincronizadas ASMH5: Analisador Sintático MHEG-5 CLSM: Componentes Locais de Servidores de Mídia
E/S: Dispositivos de Entrada e Saída

GAM: Gerenciador de Apresentações Multimídia

IUJ: Interface Usuário-JHEG

JHEG: Java MHEG-5 Engine

MAS: Módulo de Apresentação e Sincronização

UIR: Unidade de Interface de Rede

Figura 7.I - Arquitetura do Módulo MAS

O módulo GAM é responsável por prover interface com o JHEG, recebendo dele objetos MHEG-5, ou referências a tais objetos, juntamente com ações MHEG-5 que devam ser executadas em tais objetos. A principal função do GAM é identificar o tipo de ação que deve ser executada em um objeto e escolher um dos três módulos responsáveis pela apresentação do referido objeto nos dispositivos de entrada e saída. 
Os módulos responsáveis pela efetiva apresentação de objetos de mídia nos dispositivos de entrada e saída são os seguintes:

- AME - Apresentador de Mídia Estática: responsável por manipular objetos de mídia estática e objetos MHEG-5 do tipo Interactibles, tais como textos, imagens, botões, etc.;

- AMC - Apresentador de Mídia Contínua: responsável por manipular objetos do tipo Stream, como áudio e vídeo. Este módulo foi implementado a partir da API JMF Player, sendo capaz de aprésentar vários formatos de mídia contínua;

- AMS - Apresentador de Mídias Sincronizadas: Responsável por gerenciar a apresentação de duas ou mais mídias sincronizadas. Este módulo usa os serviços providos pelos módulos AME e AMC para apresentar mídias estáticas e contínuas, garantindo que as apresentações dessas mídias obedeçam as especificações de sincronização a elas associadas.

Assim, se o GAM recebe do JHEG uma ação que deve ser executada em um objeto de mídia estática que não está envolvido em uma apresentação multimídia sincronizada, o GAM ativa o módulo AME para que este realize a ação. De forma semelhante, se o GAM recebe do JHEG uma ação que deve ser executada em um objeto de mídia contínua que não esteja envolvido em uma apresentação multimídia sincronizada, o GAM ativa então o módulo AMC para que a ação seja efetivamente executada. Por outro lado, se a ação a ser realizada envolver um ou mais objetos participantes de uma apresentação multimídia sincronizada, o GAM ativa o módulo AMS para que este realize a ação levando em conta as relações de sincronização existentes entre $o(s)$ objeto(s) envolvido(s) na ação e os demais objetos participantes da apresentação multimídia em questão.

Uma outra função do MAS, não menos importante que a apresentação multimídia, é a captura das interações do usuário com os elementos de uma apresentação (objetos MHEG-5 do tipo Interactibles). Estas interações produzem eventos que devem ser passados ao módulo JHEG para que este os processem. O trabalho de capturar estas interações e passá-las ao JHEG é função do módulo IUJ, que, conforme o próprio nome diz, é o módulo responsável por prover uma interface entre o Usuário e o MHEG-5 Engine (JHEG). Cada interação do usuário é traduzida em um 
evento que, passado ao JHEG, é colocado na tabela de eventos (event table), sendo posteriormente avaliado e executado pelo engine.

\subsection{Implementação de Sincronização no MAS}

O nível de abstração provido pelo padrão MHEG-5 deixa várias questões em aberto, como, por exemplo, o esquema de endereçamento para objetos MHEG-5. Tal fato traz sérias restrições à interoperabilidade de aplicações MHEG, fazendo com que uma aplicação MHEG-5 tenha comportamentos diferentes quando executada por diferentes MHEG-5 engines. A especificação de sincronização multimídia não é, assim como o esquema de endereçamento para objetos MHEG, explicitamente especificada pelo padrão, sendo necessárias adaptações ao mesmo a fim de se prover a implementação necessária.

A seção a seguir descreve o mecanismo de especificação de sincronização existente no padrão MHEG-5, abordando suas deficiências. Em seguida, a Seção 7.3 .2 propõe uma extensão ao padrão com o objetivo de suprir estas deficiências.

\subsubsection{Especificação de Sincronização Multimídia no Padrão MHEG-5}

O padrão MHEG-5 provê duas formas de se especificar sincronização multimídia. A primeira delas baseia-se no uso de timers, implementados através de uma lista que representa as posições temporais nas quais uma cena deve receber eventos do tipo TimerFired. A segunda está associada à apresentação de streams de mídia contínua. Estes streams podem possuir uma lista de valores representando as posições temporais nas quais o Player encarregado de sua apresentação deve gerar eventos do tipo CounterTrigger.

Através do uso de timers é possível sincronizar a apresentação de uma cena a partir de um eixo de tempo global, comum a todos os elementos da cena. A criação de um timer é feita através da execução da ação SetTimer na cena ativa. Cada Timer da lista de Timers possui um identificador único, uma posição temporal expressa em milissegundos e uma ação a ser executada quando o evento TimerFired ocorrer. 
O uso de CounterTriggers, como já foi dito, está relacionado à apresentação de streams. A sincronização feita através do uso de CounterTriggers refere-se sempre ao tempo da mídia contínua que está sendo apresentada. Assim, operações como pause, fast-forward e backward realizadas no stream alteram os eventos CounterTrigger, gerando reflexos em todas as mídias a ele associadas. Eventos do tipo CounterTrigger são registrados através da ação SetCounterTrigger, que especifica um identificador único para o CounterTrigger, uma posição temporal expressa em milissegundos e uma ação a ser executada quando o evento ocorrer. Os CounterTriggers consistem em uma forma de se especificar sincronização através do uso de pontos de referência, conforme explicado na Seção 3.5.3.

A implementação desses mecanismos de sincronização é feita através do uso de threads de monitoramento. No caso dos timers, criou-se uma thread que monitora um eixo de tempo global, cujo início $(t O)$ corresponde ao início da apresentação de uma cena. Esta thread é responsável pela checagem periódica da lista de timers da cena, devendo gerar um evento do tipo TimerFired toda vez que uma entrada da lista possuir um tempo igual ou menor ao tempo global. No caso dos CounterTriggers, foi necessário criar uma thread de monitoramento para cada stream a ser apresentado em uma cena. A tarefa executada por cada uma dessas threads é semelhante à tarefa executada pela thread que controla os timers de uma cena. A única diferença é que a primeira usa um eixo de tempo global, comum a todos os elementos de uma cena, enquanto as últimas se baseiam no tempo de mídia de cada stream, gerando eventos do tipo CounterTrigger toda vez que uma entrada de sua lista possuir um tempo menor ou igual ao tempo de mídia de seu respectivo stream.

O problema existente com o mecanismo de especificação de sincronização multimídia existente no padrão MHEG-5 é que ele não permite a especificação explícita de relações de sincronização entre dois ou mais objetos de mídia contínua (streams). A sincronização entre estes objetos possível no contexto da notação textual do padrão MHEG-5 consiste em se multiplexar (codificar) os streams que se deseja apresentar sincronamente em um único objeto Stream. É isto que foi feito na aplicação "Produção de Mídia Digital", exemplo discutido no Capítulo 4, cujo código é mostrado na Figura 4.4 daquele capítulo. O áudio e o vídeo usados na aplicação foram multiplexados no momento de suas capturas, resultando em um único stream. No entanto, se 
uma aplicação exigir que estes componentes sejam apresentados de forma síncrona, mas com um atraso de $n$ segundos de um em relação ao outro (por exemplo, o áudio deve ser iniciado 5 segundos após o vídeo, e manter este atraso ao longo da apresentação) será necessário demultiplexar o stream e recodificá-lo de acordo com esta nova especificação de sincronização.

A fim de se possibilitar a especificação explícita de relações de sincronização entre dois ou mais objetos de mídia contínua no contexto do Ambiente $\mathrm{SMmD}$, foi necessário estender a notação textual do padrão MHEG-5, criando uma nova ação chamada RunSync, cuja função é especificar que dois ou mais objetos de mídia contínua devem ser apresentados simultaneamente, mantendo, ao longo de suas apresentações, relações de sincronização previamente especificadas. A seção a seguir descreve o funcionamento da ação RunSync e faz algumas considerações referentes à extensão do padrão MHEG-5 no contexto do Ambiente SMmD.

\subsubsection{Extensão do MHEG-5 para Suporte à Sincronização Multimídia}

A ação RunSync estende a notação textual do padrão MHEG-5 provendo formas de se especificar explicitamente relações de sincronização entre objetos de mídia contínua. Seu funcionamento é bastante similar ao da ação Run, definida na classe Presentable do MHEG-5. A diferença entre a ação Run e a ação RunSync é que a primeira tem como parâmetro apenas um objeto MHEG-5, enquanto a RunSync possui uma lista de objetos MHEG-5 sincronizados como parâmetros. Assim, quando o módulo GAM encontra uma ação do tipo RunSync, ele sabe que deverá ativar o módulo AMS para realizar a ação solicitada pelo JHEG.

A implementação da ação RunSync resolve o problema da especificação de sincronização entre objetos de mídia contínua, tomando possível a execução de qualquer uma das relações temporais avançadas propostas por Wahl e Rothermel, ilustradas na Figura 3.7. Mais que isso, a ação RunSync permite que se especifique relações de sincronização entre $n$ streams regidos por um mesmo eixo temporal. A Figura 7.2 mostra trechos de uma aplicação MHEG-5 que utiliza a ação RunSync. 


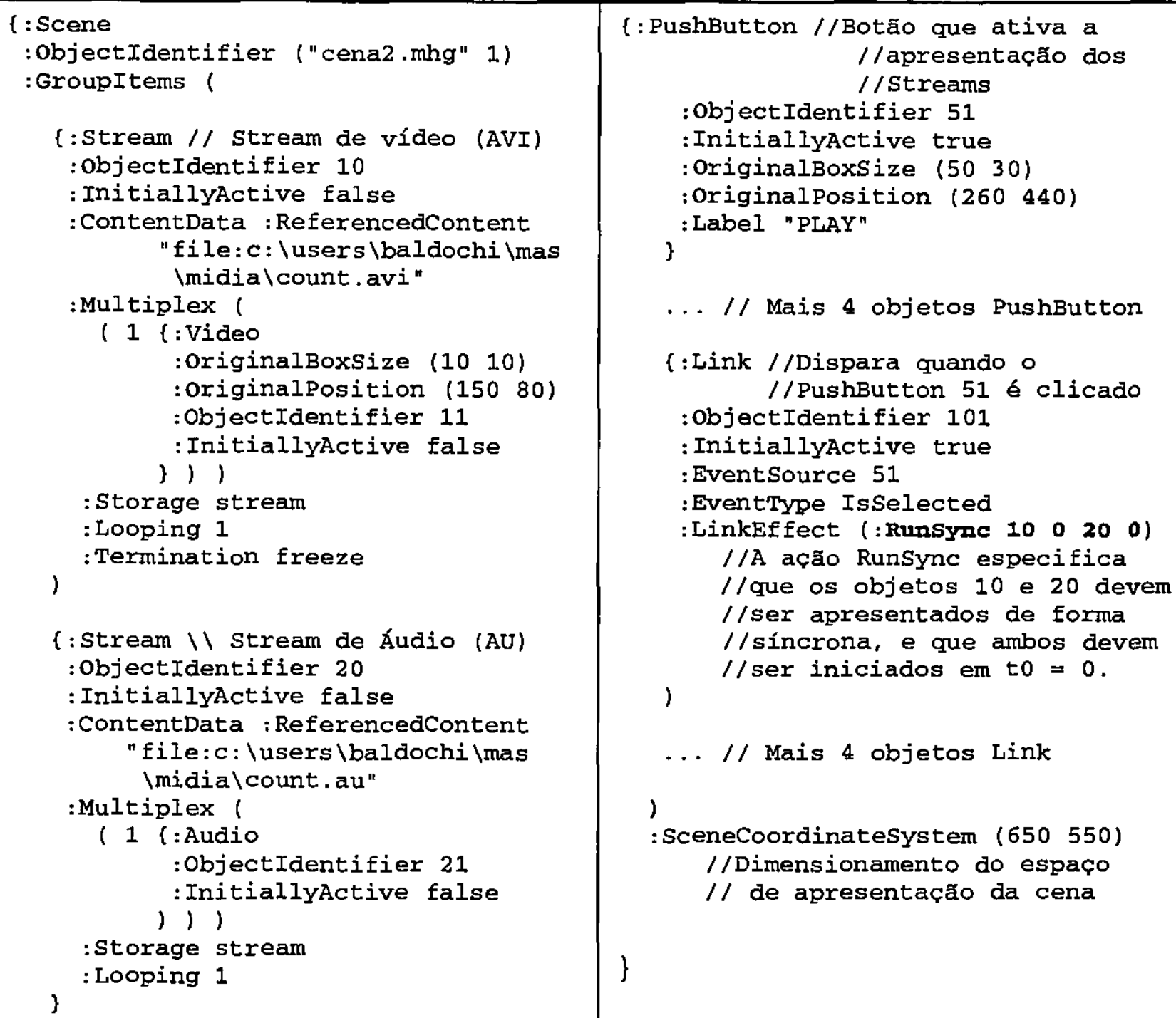

Figura 7.2 - Exemplo do uso da açāo RunSync em uma aplicaçāo MHEG-5.

Na aplicação mostrada na Figura 7.2, dois streams distintos, um de áudio e outro de vídeo, codificados em formatos diferentes (AVI e AU) são apresentados de forma síncrona. A aplicação estabelece, através da ação RunSync (mostrada em negrito na figura), que os dois streams serão iniciados ao mesmo tempo e manterão a sincronização ao longo de suas apresentaçōes. No entanto, é perfeitamente possível estabelecer, com um pequeno ajuste no código, um tempo de início aleatório para qualquer um dos streams. 
A criação da ação RunSync possibilita que o MAS apresente aplicações multimídia que usem ou não os recursos de sincronização providos pela API JMF Player. Assim, esta pequena extensão realizada na notação do padrão MHEG-5 não modifica em nada a apresentação de aplicações que seguem o padrão original, mantendo o MAS em conformidade com o MHEG-5. No entanto, é evidente que aplicações que usarem a ação RunSync provavelmente não serão corretamente apresentadas por outras máquinas MHEG-5, ficando limitadas ao Ambiente SMmD.

\subsection{Apresentação Sob Demanda e Sincronização Multimídia}

A API JMF Player possibilita a apresentação sob demanda de streams de mídia contínua. Para tanto, basta que o arquivo a ser apresentado seja do tipo streamable (MPEG e "fast-start" QuickTime) e que a conexão entre cliente e servidor seja feita através do protocolo HTTP.

O processo de apresentação de um arquivo streamable através de uma conexão HTTP e sob demanda recebe o nome de HTTP Streaming e é provido automaticamente pela API JMF Player. Para iniciar uma apresentação sob demanda usando HTTP Streaming basta chamar o método Start em um Player que esteja no estado de Prefetching (fazendo transferência do stream que irá apresentar). Assim que houver uma quantidade de dados suficiente no buffer local, o Player inicia a apresentação do stream. Se a taxa de transferência for menor que a taxa de apresentação, o buffer certamente ficará vazio em um dado momento da apresentação. Neste caso, o Player gerará um evento chamado DataStarvedEvent e interromperá a apresentação da mídia.

Além do problema causado pela incompatibilidade entre taxa de transferência e taxa de apresentação, o Gap Problem, discutido no Capítulo 3, também é responsável pelo DataStarvedEvent. O Gap Problem, neste contexto, consiste na interrupção momentânea do processo de transferência de um stream causada por falha no servidor ou sobrecarga na rede que transporta o stream. O Gap Problem pode ser desastroso quando duas ou mais mídias contínuas estão sendo apresentadas sob demanda de forma síncrona. O MAS trata o Gap Problem monitorando a apresentação de todas as mídias sincronizadas. Quando ocorre um Gap em um stream, o Player responsável pela apresentação desse stream gera um DataStarvedEvent, que pode ser capturado 
através do método ControllerUpdate ${ }^{\prime}$. Ao receber a notificação de um DataStarvedEvent em um Player sincronizado, o MAS paralisa a apresentação dos demais streams envolvidos no processo de sincronização até que o Player que sofreu o Gap volte a receber dados e tenha em seu buffer uma quantidade de mídia razoável, evitando que o buffer fique vazio rapidamente, o que geraria uma sequiência de eventos do tipo DataStarvedEvent.

O MAS reinicia a apresentação de um Stream após um DataStarvedEvent somente quando o Player acumula em seu buffer um volume de dados igual ou maior que $10 \%$ do volume total de dados do Stream como um todo. Isso é feito através do monitoramento da evolução da transferência do Stream em relação ao seu comprimento total. Este monitoramento é possível porque o método ControllerUpdate é capaz de capturar eventos do tipo CachingControl, os quais informam ao Player a chegada de dados em seu buffer, o que possibilita, inclusive, que se disponibilize um mostrador na tela que informa ao usuário a porcentagem de dados recebidos em relação ao comprimento total da mídia que está sendo apresentada.

\subsection{Considerações Finais}

Este capítulo apresentou o MAS, Módulo de Apresentação e Sincronização, abordando aspectos de seu projeto e implementação. O MAS representa a interface do projeto SMmD com o usuário. Através dele é possível testar o funcionamento de outros módulos, e, mais importante, é possível mostrar à comunidade científica o resultado prático do trabalho desenvolvido pelos pesquisadores do projeto $S M m D$.

A API JMF Player, apresentada em detalhes no Apêndice B, desempenhou um papel fundamental no desenvolvimento deste módulo. Sem ela, a implementação do MAS seria bem mais laboriosa, e os resultados obtidos certamente seriam mais modestos, sobretudo com relação à apresentação de mídias contínuas sincronizadas, pois seria necessário implementar rotinas de baixo nível para manipular as ULDs de cada stream envolvido em uma apresentação multimídia.

\footnotetext{
${ }^{1} \mathrm{O}$ funcionamento do método ControllerUpdate está descrito na Seçāo B.5 (Apêndice B).
} 
Como estas rotinas são dependentes de hardware, seria necessário construir um conjunto de rotinas para cada plataforma que se desejasse utilizar.

A implementação do Módulo MAS atingiu plenamente seu objetivo principal, que era prover o Ambiente SMmD de um mecanismo capaz de apresentar aplicações MHEG-5, compostas de objetos inter-relacionados através de relações de temporização e sincronização. No entanto, a implementação da interface entre o MAS e os outros módulos do Ambiente SMmD é ainda pequena e, em alguns casos, inexistente. Isso acontece, por exemplo, com os servidores de áudio e vídeo, que ainda não se encontram totalmente implementados. Isto faz com que apenas arquivos de mídia contínuas armazenados localmente ou disponíveis através de uma URL possam ser apresentados pelo ambiente.

Uma última consideração importante a ser feita é a extensão realizada na notação textual do padrão MHEG-5 através da incorporação da ação RunSync. Esta extensão traz como benefício a possibilidade de especificação de relações de sincronização explícitas no contexto das aplicações MHEG-5. O custo deste benefício é a limitação dessas aplicações ao Ambiente SMmD. 
"No fim tudo dá certo, se näo deu certo é porque ainda não chegou ao fim." Fernando Sabino

\subsection{Considerações Iniciais}

O Projeto SMmD investiga a construção de uma estrutura de middleware para suporte à construção de aplicações multimídia interativas em ambientes distribuídos e heterogêneos. Nesse contexto foi devenvolvido o Ambiente $\mathrm{SMmD}$, que inclui módulos para armazenamento e recuperação de objetos multimídia em conformidade com o padrão ISO MHEG-5. Esta dissertação descreveu o trabalho de implementação do Módulo de Apresentação e Sincronização (MAS) que, integrado ao módulo JHEG, provê a apresentação sincronizada de objetos multimídia em conformidade com o padrão MHEG-5.

O Módulo de Apresentação e Sincronização consiste na interface do projeto SMmD com o usuário, possibilitando demonstrar a funcionalidade de outros módulos que compõem o projeto. Procurou-se, com o trabalho desenvolvido, gerar contribuições para o desenvolvimento do modelo MHEG para aplicações multimídia distribuídas, sobretudo nos aspectos relacionados à implementação de mecanismos que possibilitem a apresentação de mídias contínuas sincronizadas.

Este capítulo se encontra subdividido da seguinte forma: a Seção 8.2 relaciona as contribuições geradas por este trabalho; a Seção 8.3 enumera algumas possibilidades de se dar continuidade ao trabalho desenvolvido; finalmente, a Seção 8.4 encerra esta dissertação resumindo os pontos mais relevantes do trabalho realizado. 


\subsection{Contribuições Geradas}

Além do próprio Módulo de Apresentação e Sincronização, cuja implementação consiste no resultado prático desta dissertação, outras atividades foram realizadas, gerando contribuições importantes. Entre elas está a implementação do applet SyncEvent, através do qual foi possível demonstrar a viabilidade do esquema proposto por Pimentel et al. [Pim97a] [Pim97b] para apresentação de mídias contínuas sincronizadas, especificadas através do padrão HyTime de acordo com as relações temporais binárias propostas por Allen.

Também relacionado com o desenvolvimento do applet SyncEvent está o trabalho de pesquisa feito com a API JMF Player, através da qual foi possível realizar um mapeamento de objetos MHEG-5 para objetos Player, e assim implementar as funcionalidades necessárias à apresentação de mídias contínuas no contexto do MAS. Utilizando esta mesma API foi possível também implementar mecanismos capazes de interpretar dependências temporais entre duas ou mais mídias, possibilitando a implementação de mecanismos capazes de suportar a especificação de apresentações multimídia pré-orquestradas.

Entre as contribuições geradas diretamente pela implementação do MAS, a mais importante foi, sem dúvida, a implementação do módulo Apresentador de Mídias Sincronizadas (AMS), mostrado na Figura 7.1. Este módulo realiza o mapeamento de objetos e ações MHEG-5 em objetos e métodos Java responsáveis pela efetiva apresentação de mídias sincronizadas, provendo a funcionalidade necessária ao módulo MAS.

Além dessa, existem ainda três outras contribuições importantes geradas por este trabalho:

- Implementação das primitivas que permitem a comunicação entre os módulos MAS e JHEG;

- Definição de uma extensão para a notação textual do padrão MHEG-5, possibilitando a especificação de relações de sincronização entre dois ou mais objetos do tipo Stream;

- Expansão do analisador sintático MHEG-5 responsável por analisar arquivos MHEG-5 e criar instâncias dos objetos contidos nestes arquivos. Esta expansão foi feita para incorporar ao 
analisador açōes relacionadas com objetos Stream, sobretudo aquelas referentes à sincronização desses objetos, como a ação RunSync, por exemplo.

A seguir são discutidas algumas formas de se dar continuidade ao trabalho descrito nesta dissertação.

\subsection{Trabalhos Futuros}

Apesar de todos os módulos do projeto SMmD já estarem concluídos, ou em fase final de conclusão, o trabalho de integração desses módulos ainda é pequeno. Com exceção do JHEG e do MAS, que se encontram totalmente integrados, os demais módulos ainda necessitam de uma interface que os integrem ao Ambiente SMmD. De particular importância a este trabalho é a integração do MAS com os Servidores de Áudio, Vídeo e Objetos Multimídia. Esta integração consiste em um trabalho futuro desta dissertação em particular, e do Projeto SMmD em geral.

Um outro trabalho futuro, descrito na Seção 6.5 e ilustrado pela Figura 6.3, consiste na implementação de um tradutor capaz de transformar aplicações MHEG-5 em aplicações SMIL e vice-versa. Este tradutor possibilitaria a apresentação de aplicações MHEG-5 no contexto da WWW, ampliando significativamente o alcance do Ambiente SMmD. De forma análoga, este tradutor também permitiria que aplicaçōes SMIL fossem apresentadas no Ambiente SMmD.

Uma outra proposta envolvendo a tradução de aplicações MHEG-5 em aplicações ou especificações em outros formatos ou padrões, consiste na elaboração de um DTD SGML que formalize o padrão MHEG-5. À partir da elaboração deste DTD seria possível criar ferramentas capazes de mapear aplicações MHEG-5 para qualquer formato que possa ser formalizado por um DTD SGML, como é o caso do HyTime e do SMIL, por exemplo. Rutledge et al. discute as formas de se realizar traduções semelhantes em uma série de artigos, entre os quais estão [Rut97] e [Rut98].

Uma última sugestão como trabalho futuro seria o estudo da viabilidade de se estender o uso do MAS para outros MHEG-5 engines. Para tanto seria necessário adaptar estes engines a fim de 
que eles pudessem reconhecer a extensão feita pela inserção da ação RunSync na notaçăo textual do MHEG-5 .

\subsection{Considerações Finais}

O trabalho descrito nesta dissertação alcançou plenamente seus objetivos, gerando uma série de contribuições já descritas. Entre os vários pontos positivos do trabalho realizado está a geração de um produto final, o Módulo de Apresentação e Sincronização, que, apesar de possuir algumas limitações, encontra-se totalmente funcional. Um outro ponto positivo do trabalho realizado foi o estudo comparativo de uma série de padrões e recomendações ligados à especificação de apresentações multimídia. A partir de tais estudos foi possível investigar possíveis relações entre estes padrões e recomendações, o que resultou em uma série de propostas para realização de trabalhos futuros. 
[Abr97] I. C. Abrão; Ambiente para o Intercâmbio de Objetos Multimídia em Sistemas Distribuídos e Heterogêneos. Dissertação de Mestrado defendida junto ao PPG do DC-UFSCar, setembro, 1997.

[All83] J. F. Allen; Maintaining Knowledge about Temporal Intervals. Communications of the ACM, pp. 832-843, novembro, 1983.

[Alv95] H. Alvestrand; RFC 1766 - Tags for the Identification of Languages, março, 1995. Disponível em ftp://ftp.internic.net/rfc/rfc1766.txt.

[AT96] A. de Angelis e C. A. C. Teixeira; Serviço de Vídeo do Projeto SMmD. Anais do XXIII Seminário Integrado de Software e Hardware - SEMISH'96, Recife-PE, pp. 309-320, agosto, 1996.

[AWT97] The AWT in 1.0 and 1.1. Sun Micro Systems Inc, 1997. Disponível em http://Java.sun.com/products/jdk/awt.

[Bos97] J. Bosak; XML, Java and the Future of the Web, março, 1997. Disponível em http://sunsite.unc.edu/pub/sun-info/standards/xml/why/xmlapps.html

[Bro98] K. Brown; Synchronizing the Web, janeiro, 1998. Disponível em http://webreview.com/98/01/09/feature/smil.html.

[Buf94] J. F. K. Buford et al.; Multimedia Systems. ACM Press, 1994.

[DAV96] DAVIC Specification; Techical Report, 1996. Disponível em http://www.davic.org.

[Ech98] M. Echiffre et al.; MHEG-5 - Aims, Concepts, and Implementation Issues. IEEE Multimedia, January/March Issue, vol. 5, no. 1, pp. 84-91, 1998.

[EF194] L. Ehley, B. Furth, M. Ilyas; Evaluation of Multimedia Synchronization Techniques. In Proceedings of the International Conference on Multimedia Computing and Systems, Boston, MA, pp.110-119,maio, 1994.

[FT97] M. M. Ferreira e L. C. Trevelin; Um Servidor de Áudio Distribuído com Edições Dinâmicas. XXIII Conferência Latinoamericana de Informática, CLEI97, Valparaíso, Chile, pp. 715-724, novembro, 1997. 
[GM96] J. Gosling, H. McGilton; The Java Language Environment - A White Paper. Sun Micro Systems Inc, Maio, 1996. Disponível em: http://www.javasoft.com /docs/white /langenv/index.html

[HSA89] M. E. Hodges, R. M. Sasnett, M. S. Ackerman; Athena Muse: A Construction Set for Multimedia Applications. IEEE Software, pp. 37-43, janeiro, 1989.

[IET98] IETF RFC 2326: Real Time Streaming Protocol. Draft, 1998. Disponível em ftp://ftp.isi.edu/in_notes/rfc2326.txt

[ISO76] ISO 8879, Standard Generalized Markup Language - SGML, 1976.

[ISO90a] ISO/IEC 8824, Specification of Abstract Syntax Notation One - ASN.1, 1990.

[ISO90b] ISO/IEC 8825, Specification of Basic Encoding Rules for Abstract Sintax Notation One - ASN.1, 1990.

[ISO92] ISO 10744, Hypermedia/Time-Based Structuring Language - HyTime, 1992.

[ISO97] ISO/IEC 13522-5: Information Technology - Coding of Multimedia and Hypermedia Information - Part 5: Suport for Base Level Interactive Applications, Março, 1997.

[JB97] JavaBeans API Specification. Sun Micro Systems Inc, 1997. Disponível em: http://javasoft.com/beans/docs/beans 101.pdf

[JMP97] Java Media Players Guide, Version 1.0.1, Setembro, 1997. Disponível em: http://developer.inte.com/ial/jmedia/Docs/JMFramework/JavaDoc/playerguide.pdf

[JR95] R. Joseph, J. Rosengren; MHEG-5: An Overview, 1995. Disponível em http://fokus.gmd.de/ovma/mug/archives/documents/mheg-reader/rd1206.html

[Key94] J. Keyes; Multimedia Handbook. McGraw-Hill, 1994.

[LG90] T. D. C. Little, A. Ghafoor; Network Considerations for Distributed Multimedia Objects Composition and Communications. IEEE Network Magazine, pp. 32-39, novembro, 1990.

[LG92] T. D. C. Little, A. Ghafoor; Scheduling of Bandwidth-Constrained Multimedia Traffic. Computer Communication, pp. 381-387, julho, 1992. 
[LV95] T. D. C. Little, D. Venkatesh; The Use o Multimedia Tecnology; Distance Learning. Proceedings of the International Conference on Multimedia Networking, Aiuzu - Japan, pp. 03-17, setembro, 1995.

[MES93] T. Meyer, W. Effelsberg, R. Steinmetz; A Taxonomy on Multimedia Synchronization. In Proceedings of the 4th International Workshop on Future Trends in Distributed Computing Systems, Lisbon, Portugal, setembro, 1993.

[Pim95] M. Pimentel; O HyTime no Contexto do Projeto SMmD. Anais do I Workshop em Sistemas Hipermídia Distribuídos, pp. 67-77, 1995.

[Pim97a] M. Pimentel et al.; Relaçôes Temporais em Objetos Multimídia: Especificaçâo HyTime e Apresentação. III Workshop em Sistemas Hipermídia e Multimídia, São Carlos, maio, 1997.

[Pim97b] M. Pimentel et al.; Temporal Relations in Multimedia Objects: WWW Presentation from HyTime Specification. Proceedings of the IEEE Conference on Protocols for Multimedia Systems and Multimedia Networking, Santiago, Chile, novembro, 1997.

[Pri98] R. Price; Beyond SGML. Proceedings of Digital Libraries 98, pp. 172-181, junho, 1998.

[Rum91] J. Rumbaugh et al.; Object Oriented Modeling and Design. Prentice-Hall, 1991.

[Rut97] L. Rutledge et al.; Cooperative Use of MHEG-5 and HyTime. Proceedings of Hypertexts and Hypermedia: Products, Tools, Methods, pp. 57-73, setembro, 1997.

[Rut98] L. Rutledge et al.; Practical Application on Existing Hypermedia Standards and Tools, Proceedings of Digital Libraries 98, pp. 191-199, junho, 1998.

[SE93] R. Steinmetz, C. Engler; Human Perception of Media Synchronization. Technical Report 43.9310, IBM European Networking Center Heidelberg, Heidelberg, Germany, 1993.

[SN95] R. Steinmetz, K. Nahrstedt; Multimedia: Computing, Communications \& Applications. Prentice Hall, 1995.

[Ste95] R. Steven; Multimedia Interchange Using SGML/HyTime - Part I: Structures. IEEE Multimedia, Summer 1995.

[Sun97] Java and the Java Virtual Machine, 1997. Disponível em http://www.Java.sun.com. 
[SV98] F. C. Santos e M. T. P. Vieira; SMArT: Ambiente para Autoria de Aplicações MHEG-5. IV Simpósio Brasileiro de Sistemas Multimídia e Hipermídia, Rio de Janeiro, pp. 39-50, maio, 1998.

[SVF97] M. T. P. Santos, M. T. P. Vieira e J. M. Figueiredo; Extensão de um Banco de Dados de Objetos MHEG-5 para Suportar Busca por Conteúdo. Anais do XII Simpósio Brasileiro de Banco de Dados, Fortaleza, pp. 107-121, outubro, 1997.

[Tei94] C. A. Teixeira et al.; SMmD - Sistemas Multimidia Distribuídos: Suporte, Estruturas e Aplicações. Plano de projeto temático aprovado no ProTeM-CC fase II, CNPq - 1994.

[Tei98] C. A. Teixeira et al.; SMmD - A MHEG-5 Based Disitributed Multimedia System. ProTeM-CC Conference, Belo Horizonte, abril, 1998.

[TGD91] D. Tsichritzis; S. Gibbs; L. Dami; Active Media. In Object Composition (D. Tsichritzis, ed.). Universite de Geneve, Centre Universitaire d'Informatique, Geneve, pp. 115-132, junho, 1991.

[Tre95] L. C. Trevelin; Projeto SMmD: uma Visäo Geral. Anais do I Workshop em Sistemas Hipermídia Distribuídos, São Carlos, 1995.

[VS97] M. T. P. Vieira e M. T. P. Santos; Content-based Search on a MHEG-5 Standardbased Multimedia Database. Proceedings of the QPMIDS DEXA 97, Toulouse-FR, pp. 154-159, setembro, 1997.

[W3C98a] Synchronized Multimedia Integration Language (SMIL) 1.0 Specification - W3C Proposed Recommendation, abril, 1998. Disponível em http://www.w3.org /TR/1998/PR-smil-19980409

[W3C98b] Extensible Markup Language (XML) 1.0 - W3C Recommendation, fevereiro, 1998. Disponivel em http://www.w3.org/TR/1998/REC-xml-19980210.html

[WR94] T. Wahl, K. Rothermel; Representing Time in Multimedia Systems. In Proceedings of the Intemational Conference on Multimedia Computing and Systems, Boston, MA, pp. 538-543, maio, 1994. 


\section{Notação Textual da Aplicação Produção de Mídia Digital}

\author{
(:Application \\ :ObjectIdentifier ("startup" 0) \\ \} \\ :OnStartup ( :TransistionTo (("cenal.mhg" 0) 1)) \\ $\{:$ Scene \\ :ObjectIdentifier ("aplic/cenal.mhg" 1) \\ :OnStartUp ( :SetCounterTrigger (10 1 1000) \\ :SetCounterTrigger (10 239000$)$ \\ :SetCounterTrigger (10 340000$)$ \\ :SetCounterTrigger (10 453000$)$ \\ :SetCounterTrigger (10 554000$)$ \\ :SetCounterTrigger (10 6 65000) \\ :SetCounterTrigger (10766000) \\ :SetCounterTrigger (10 8 79000) \\ :SetCounterTrigger (10 980000$)$ \\ :SetCounterTrigger (10 1085000$)$ \\ :SetCounterTrigger (10 11 86000) \\ :SetCounterTrigger (10 12 94000) \\ :SetCounterTrigger (10 13 95000) \\ :SetCounterTrigger (10 14 131000) \\ :SetCounterTrigger (10 15 132000) \\ :SetCounterTrigger (10 16 151000) \\ :SetCounterTrigger (10 17 152000) \\ :SetCounterTrigger (10 18 171000))
}

:GroupItems (

\{:Stream

:ObjectIdentifier 10

:InitiallyActive false

:ContentData :ReferencedContent

"file:c:luserslbaldochilmastmidialaquis_video.avi"

:Multiplex ( ( 8

\{:video

:OriginalBoxSize (10 10)

:OriginalPosition (150 123)

:ObjectIdentifier 20

\}))

:InitiallyActive true

:Storage stream

:Looping 1
:Termination freeze

\}

$\{:$ Text

:ObjectIdentifier 40

:InitiallyActive true

:ContentData :InciudedContent "Produção

:OriginalBoxSize (370 60)

de Mídia Digital"

:OriginalPosition (160 40)

:FontRef "Helvetica"

:FontAttributes "style $=$ normal,size $=30$ "

:TextColour "222"

:BackgroundColour "44"

\}

\{:Text

:ObjectIdentifier 41

:InitiallyActive false

:ContentData :InciudedContent "Captura de Vídeo"

:OriginalBoxSize (370 60)

:OriginalPosition (180 300)

:FontRef "Helvetica"

:FontAttributes "style=normal,size $=20$ "

:TextColour "222"

:BackgroundColour "44"

\}

$\{:$ Text

:Objectldentifier 42

:InitiallyActive false

:ContentData :IncludedContent "Câmeras

:OriginalBoxSize (370 60)

de Vídeo"

:OriginalPosition (180 300)

:FontRef "Helvetica"

:FontAttributes "style $=$ normal,size $=20$ "

:TextColour "222"

:BackgroundColour "44" 
$\{:$ Text

:ObjectIdentifier 43

:InitiallyActive false

:ContentData :IncludedContent

"Minicâmeras"

:OriginalBoxSize (370 60)

:OriginalPosition (180 300)

:FontRef "Helvetica"

:FontAttributes "style $=$ normal, size $=20$ "

:TextColour "222"

:BackgroundColour "44"

1

$\{:$ Text

:ObjectIdentifier 44

:InitiallyActive false

:ContentData :IncludedContent "Video

Blaster"

:OriginalBoxSize (370 60)

:OriginalPosition (180 300)

:FontRef "Helvetica"

:FontAttributes "style=normal,size $=20$ "

:TextColour "222"

:BackgroundColour "44"

\}

$\{:$ Text

:ObjectIdentifier 45

:InitiallyActive false

:ContentData :IncludedContent

"Microfones"

:OriginalBoxSize (370 60)

:OriginalPosition (180 300)

:FontRef "Helvetica"

:FontAttributes "style=normal,size $=20$ "

:TextColour "222"

:BackgroundColour "44"

\}

$\{:$ Text

:ObjectIdentifier 46

:InitiallyActive false

:ContentData :IncludedContent "Mídias Prégravadas"

:OriginalBoxSize (370 60)

:OriginalPosition (180 300)

:FontRef "Helvetica"

:FontAttributes "style $=$ normal,size $=20$ "

:TextColour "222"

:BackgroundColour "44"

\}

$\{:$ Text

:ObjectIdentifier 47

:InitiallyActive false

:ContentData :IncludedContent
"Sintetizadores"

:OriginalBoxSize (370 60)

:OriginalPosition (180 300)

:FontRef "Helvetica"

:FontAttributes "style $=$ normal,size $=20$ "

:TextColour "222"

:BackgroundColour "44"

1

$\{:$ Text

:ObjectIdentifier 48

:InitiallyActive false

:ContentData :IncludedContent "Sound

Blaster"

:OriginalBoxSize (370 60)

:OriginalPosition (180 300)

:FontRef "Helvetica"

:FontAttributes "style=normal,size $=20$ "

:TextColour "222"

:BackgroundColour "44"

1

$\{:$ Text

:ObjectIdentifier 49

:InitiallyActive false

:ContentData :IncludedContent "Scanners"

:OriginalBoxSize (370 60)

:OriginalPosition (180 300)

:FontRef "Helvetica"

:FontAttributes "style=normal,size $=20 "$

:TextColour "222"

:BackgroundColour "44"

1

$\{:$ PushButton

:ObjectIdentifier 61

:InitiallyActive true

:OriginalBoxSize (170 30)

:OriginalPosition (360 130)

:Label "Captura de Vídeo"

l

$\{:$ PushButton

:ObjectIdentifier 62

:InitiallyActive true

:OriginalBoxSize (170 30)

:OriginalPosition (360 160)

:Label "Digitalização de Vídeo"

\}

$\{:$ PushButton

:ObjectIdentifier 63

:InitiallyActive true

:OriginalBoxSize (170 30)

:OriginalPosition (360 190)

:Label "Captura de Áudio" 
\}

\{:PushButton

:ObjectIdentifier 64

:InitiallyActive true

:OriginalBoxSize (170 30)

:OriginalPosition (360 220)

\}

:Label "Digitalização de Áudio"

$\{:$ PushButton

:ObjectIdenlifier 65

:InitiallyActive true

:OriginalB oxSize (170 30)

:OriginalPosition (360 250)

1

:Label "Captura de Imagens"

\{:PushButton

:ObjectIdentifier 66

:InitiallyActive true

:OriginalBoxSize (50 30)

:OriginalPosition (260 440)

)

:Label "PLAY"

$\{:$ PushButton

:ObjectIdentifier 67

:InitiallyActive true

:OriginalBoxSize (60 30)

:OriginalPosition (310 440)

1

:Label "PAUSE"

[:PushButton

:ObjectIdentifier 68

:InitiallyActive true

:OriginalBoxSize (35 30)

:OriginalPosition (275 470)

:Label "<"

)

$\{$ PushButton

:ObjectIdentifier 69

:InitiallyActive true

:OriginalBoxSize (35 30)

:OriginalPosition (310 470)

:Label ">"

1

[:PushButton

:ObjectIdentifier 70

:InitiallyActive true

:OriginalBoxSize (80 30)

:OriginalPosition (270 500)
:Label "FM"

\}

\{:Link

:ObjectIdenlifier 201

:InitiallyActive true

:EventSource 1

:EventType CounterTriggerFired

:EventData 1

:LinkEffecl ( :Run 41 )

1

\{:Link

:ObjectIdentifier 202

:InitiallyActive true

:EventSource 1

:EventType CounterTriggerFired

:EventData 2

:LinkEffect ( :Stop 41)

\}

\{:Link

:ObjectIdentifier 203

:InitiallyActive true

:EventSource 1

:EventType CounterTriggerFired

:EventData 3

\}

:LinkEffect ( :Run 42)

\{:Link

:ObjectIdentifier 204

:InitiallyActive true

:EventSource I

:EventType CounterTriggerFired

:EventData 4

:LinkEffect ( :Stop 42 )

\}

[:Link

:ObjectIdentifier 205

:InitiallyActive true

:EventSource I

:EventType CounterTriggerFired

:EventData 5

:LinkEffect ( :Run 43)

)

[:Link

:ObjectIdentifier 206

:InitiallyActive true

:EventSource I

:EventType CounterTriggerFired

:EventData 6

:LinkEffect ( :Stop 43 ) 
\{:Link

:ObjectIdentifier 207

:InitiallyActive true

:EventSource 1

:EventType CounterTriggerFired

:EventData 7

:LinkEffect ( :Run 44 )

1

\{:Link

:ObjectIdentifier 208

:InitiallyActive true

:EventSource 1

:EventType CounterTriggerFired

:EventData 8

)

:LinkEffect ( :Stop 44 )

\{:Link

:ObjectIdentifier 209

:InitiallyActive true

:EventSource 1

:EventType CounterTriggerFired

:EventData 9

1

:LinkEffect (:Run 45)

\{:Link

:ObjectIdentifier 210

:InitiallyActive true

:EventSource I

:EventType CounterTriggerFired

:EventData 10

)

:LinkEffect ( :Stop 45)

$\{:$ Link

:ObjectIdentificr $21 \mathrm{I}$

:InitiallyActive true

:EventSource 1

:EventType CounterTriggerFired

:EventData 11

)

:LinkEffect ( :Run 46)

\{:Link

:ObjectIdentifier 212

:InitiallyActive true

:EventSource !

:EventType CounterTriggerFired

:EventData 12

)
\{:Link

:ObjectIdentifier 213

:InitiallyActive true

:EventSource 1

:EventType CounterTriggerFired

:EventData 13

\}

:LinkEffect ( :Run 47)

\{:Link

:ObjectIdentifier 214

:InitiallyActive true

:EventSource 1

:EventType CounterTriggerFired

:EventData 14

)

:LinkEffect ( :Stop 47)

$\{:$ Link

:ObjectIdentifier 215

:InitiallyActive true

:EventSource 1

:EventType CounterTriggerFired

:EventData 15

\}

:LinkEffect ( :Run 48 )

\{:Link

:ObjectIdentifier 216

:InitiallyActive true

:EventSource 1

:EventType CounterTriggerFired

:EventData 16

:LinkEffect ( :Stop 48 )

\}

\{:Link

:ObjectIdentifier 217

:InitiallyActive true

:EventSource 1

:EventType CounterTriggerFired

:EventData 17

)

:LinkEffect ( :Run 49)

\{:Link

:ObjectIdentifier 218

:InitiallyActive true

:EventSource 1

:EventType CounterTriggerFired

:EventData 18

\} 
\{:Link

:ObjectIdentifier 102

:InitiallyActive true

:EventSource 51

:EventType IsSelected

:LinkEffect ( :Run 10)

)

\{:Link

:ObjectIdentifier 103

:InitiallyActive true

:EventSource 52

:EventType IsSelected

:LinkEffect ( :SetSpeed (1001))

\}

\{:Link

:ObjectIdentifier 104

:InitiallyActive true

:EventSource 53

:EventType IsSelected

:LinkEffect ( :SetCounterPosition

$(10-30000))$
\{:Link

:ObjectIdentifier 105

:InitiallyActive true

:EventSource 54

EventType IsSelected

:LinkEffect ( :SetCounterPosition

\}

(10 3000 0))

\{:Link

:ObjectIdentifier 106

:InitiallyActive true

:EventSource 55

:EventType IsSelected

:LinkEffect ( :Quit "startup")

\}

)

:InputEventRegister 1

:SceneCoordinateSystem (650 550)

:MovingCursor true

\} 


\section{A API Java Media Framework Player}

O ambiente provido pela Java Virtual Machine [GM96] oferece suporte multithreading para a execução simultânea de váriạs tarefas. Assumindo que cada uma dessas tarefas seja a apresentação de uma mídia que obedeça relações temporais previamente estabelecidas, pode-se dizer que a linguagem Java é uma ferramenta adequada para o desenvolvimento de aplicações multimídia. No entanto, prover suporte multithreading não é tudo que se espera de tal ferramenta. É necessário também prover facilidades para a apresentação de cada uma das mídias que compõem uma apresentação multimídia.

Até a segunda metade de 1996, a linguagem Java dispunha apenas da API AWT (Abstract Windowing Toolkit) [AWT97] para exibir objetos na tela do usuário. Esta API possibilitava a apresentação de mídia discretas, como textos e bitmaps, mas, no entanto, não oferecia nenhum suporte para a apresentação de mídias contínuas. Nessa época, três empresas da indústria de hardware - Intel, Sun Microsystems e Silicon Graphics - interessadas sobretudo na difusão de seus produtos voltados à apresentação multimídia, iniciaram o desenvolvimento de uma API capaz de dar suporte à apresentação de mídias contínuas usando a Java Virtual Machine. Esta API recebeu o nome de Java Media Framework Player (JMF Player) [JMP97], pois é parte integrante da especificação Java Media Framework (JMF), que também especifica APIs para captura de mídia e vídeo/áudio conferência (ainda não disponíveis). A primeira versão da API JMF Player foi disponibilizada no início de 1997 pela Intel para plataformas Windows 95/NT. No segundo semestre de 1997, foi a vez da Sun Microsystem disponibilizar sua versão da API para plataformas Solaris e Windows 95/NT.

Com esta nova API, a linguagem Java, que já oferecia suporte multithreading, passou a oferecer também suporte à apresentação de mídias contínuas. Em sua configuração atual, a API JMF Player suporta uma variedade de tipos de conteúdo de mídia, como MPEG-1, MPEG-2, 
QuickTime, AVI, WAV, AU e MDI, sendo capaz de recuperar mídias contínuas de servidores remotos e apresentá-las. Além disso, a API JMF Player provê também suporte para sincronização intermídia, possibilitando que apresentações multimídia completamente sincronizadas sejam apresentadas.

Este apêndice está organizado da seguinte forma: a Seção B.1 apresenta o objeto Player, conceito central da API aqui apresentada; a Seção B.2 aborda os eventos de mídia que um objeto Player é capaz de capturar e tratar; a Seção B.3 trata dos estados de um objeto Player, mostrando quais açōes podem ser executadas por um Player nos seus diversos estados de execução; a Seção B.4 aborda os métodos responsáveis por prover a funcionalidade de um objeto Player; a Seção B.5 apresenta a Interface ControllerListerner, através da qual um Player é notificado da ocorrência de eventos de mídia; finalmente, a Seção B.6 apresenta os mecanismos de gerenciamento de temporização e sincronização existentes na API JMF Player.

\section{B.1. O Objeto Player}

A API JMF Player introduz o conceito de Player, que nada mais é que um objeto que processa um fluxo de dados à medida que o tempo transcorre, apresentando-os em um instante preciso. A leitura de tais dados é feita a partir de um DataSource, o qual encapsula a localização da mídia e também o protocolo e o software usados para a distribuição da mesma. O DataSource de um Player é identificado por um JMF MediaLocator (classe do JMF Player que descreve a mídia apresentada por um Player) ou por um URL - Universal Resource Locator. Em sua configuração atual, a API JMF Player suporta os protocolos FILE, HTTP e RTP.

A fim de prover a funcionalidade requerida, um JMF Player implementa quatro interfaces básicas, mostradas na Figura B.1. São elas:

- Interface Clock: define as operações básicas de temporização e sincronização que um Player utiliza para controlar a apresentação de uma mídia; 
- Interface Controller: estende a interface Clock, provendo métodos para obtenção ou alocação de recursos do sistema e pré-carregamento de dados a serem apresentados. Provê também um mecanismo de listening que permite a recepção de notificações de eventos de mídia;

- Interface Duration: provê meios de se determinar a duração da mídia que está sendo apresentada em um dado momento;

- Interface Player: estende a interface Controller provendo um painel de controle padrão para o usuário, que lhe permite controlar a execução de uma apresentação multimídia.

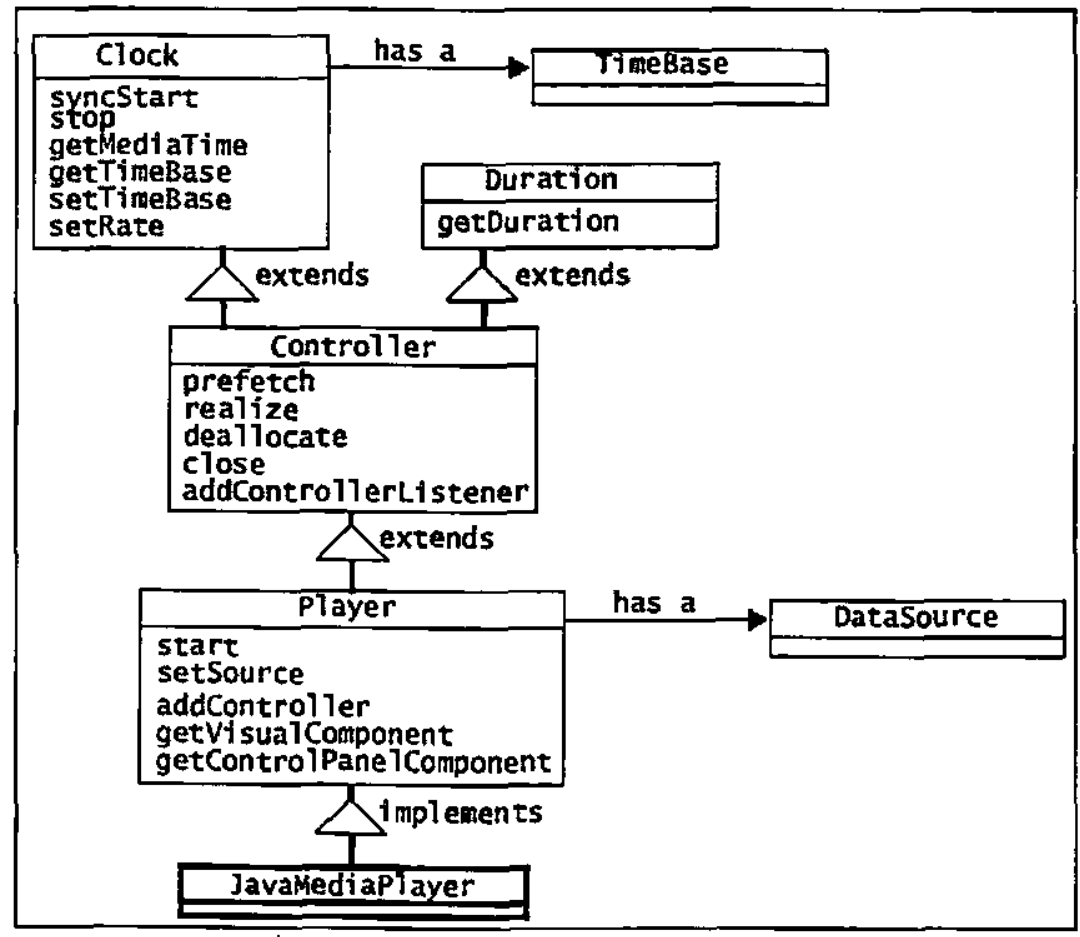

Figura B.I - A Interface Player [JMP97]

\section{B.2. Eventos de Mídia}

O mecanismo de notificação de eventos do JMF Player permite que um programa responda a condições de erro especificamente relacionadas à apresentação de mídias contínuas, como faita de dados em uma transferência sob demanda ou indisponibilidade do recurso desejado. Este 
sistema de eventos também provê um protocolo de notificação essencial à apresentação multimídia, já que toda vez que se chama um método assíncrono em um Player só é possível saber se o método foi corretamente executado através da recepção de um evento apropriado, relacionado com o método invocado.

Existem dois tipos de objetos JMF Player que geram eventos: objetos do tipo GainControl e do tipo Controller. Estes objetos seguem o padrão Java Beans [JB97] para geração de eventos.

Objetos do tipo GainControl geram apenas um tipo de evento, chamado GainChangeEvent. Este evento é gerado toda vez que um objeto do tipo GainControl recebe o foco (ou seja, é selecionado ou ativado). Para responder à mudança de foco deve-se implementar a interface GainChangeListener.

Objetos do tipo Controller podem gerar uma variedade de eventos derivados do evento ControllerEvent. Para receber eventos de um Controller deve-se implementar a interface ControllerListener (a interface ControllerListener é abordada em detalhes na seção B.5). A Figura B.2 mostra os eventos que podem ser gerados por um Controller.

Eventos do tipo ControllerEvent se dividem em três categorias: notificações de mudança (change notifications), eventos de fechamento (closed events) e eventos de transição (transition events), conforme indicado na Figura B.2.

Eventos de notificação de mudança, como RateChangeEvent e DurationUpdateEvent, indicam que algum atributo do Player se modificou, geralmente em resposta à invocação de um método. Por exemplo, um Player gera um evento do tipo RateChangeEvent quando sua taxa de apresentação é modificada pela invocação do método setRate.

Eventos de transição (TransitionEvents) permitem que um programa responda a mudanças no estado de um Player. Um Player gera eventos de transição toda vez que passa de um estado para outro (veja a Seção B.3 para maiores informações a respeito dos estados de um Player). 


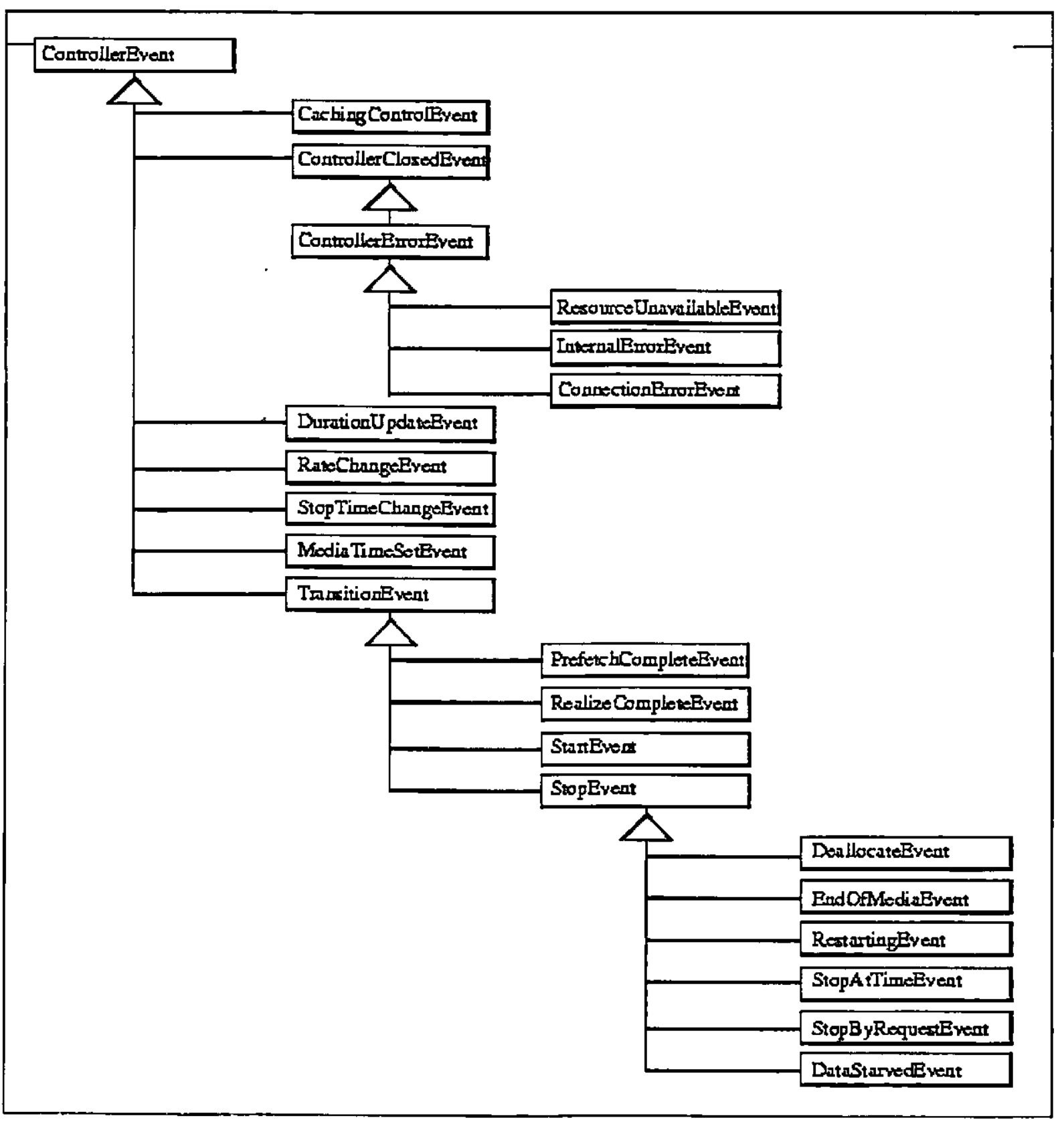

Figura B.2 - Eventos gerados por um Controller [JMP97]

Eventos de fechamento (ControllerClosedEvents) são gerados por um Player quando este realiza o processo de shut-down. Quando um Player gera um evento de fechamento ele não pode mais ser usado. Eventos de erro (ControllerErrorEvents) são um tipo especial de eventos de fechamento. É importante gerenciar os eventos de erro para que o programa possa responder ao mau funcionamento de um Player, minimizando o impacto desse mau funcionamento sobre o usuário. 


\section{B.3. Estados de um Player}

A fim de estar apto para apresentar um arquivo de mídia contínua, um Player deve realizar uma série de operações relacionadas à obtenção de recursos para apresentação da mídia e ao carregamento dessa mídia a partir de um servidor remoto, se for o caso. Uma vez que essas operações podem consumir um tempo considerável, o JMF Player permite controlar a execução de cada uma delas definindo um conjunto de estados operacionais para os Players e provendo mecanismos de controle que permitem mudar um Player de um estado para outro.

Em um determinado instante um Player pode estar em um de seis estados possíveis. Estes estados, como mostra a Figura B.3 são os seguintes: Unrealized, Realizing, Realized, Prefetching, Prefetched e Started. Conhecer o estado de um Player é fundamental para seu gerenciamento, pois a maioria dos métodos definidos nas interfaces citadas na Seção B.1 só podem ser invocados em determinados estados de um Player.

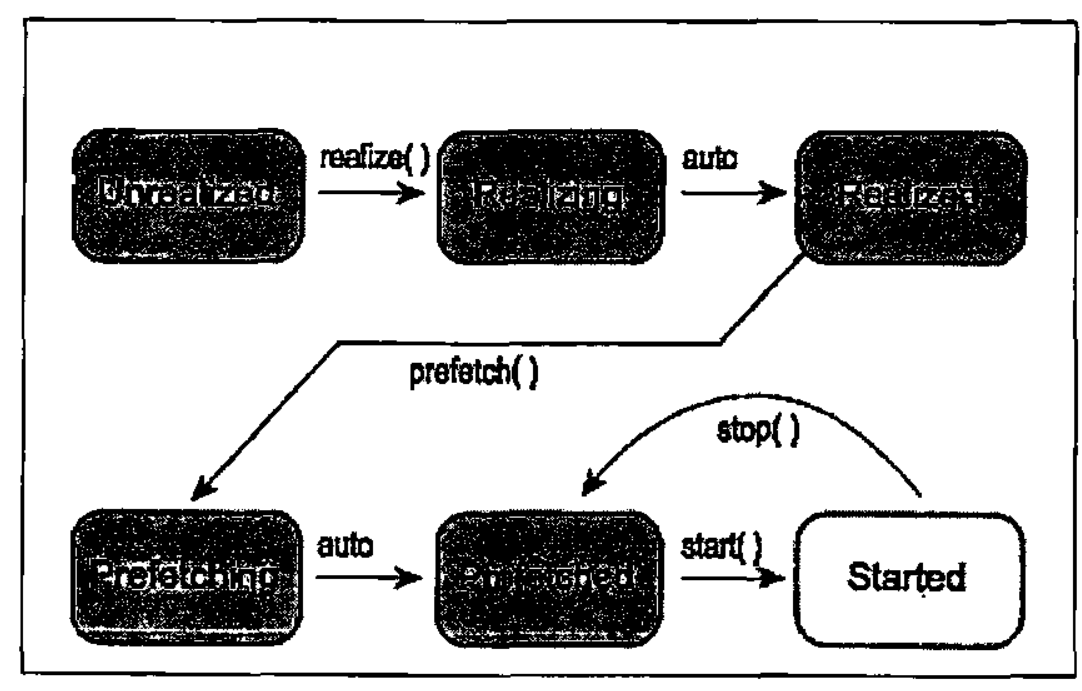

Figura B.3 - Estados de um Player

Em condiçбes normais de operação, um Player atravessa cada um dos estados mostrados na Figura B.3 até alcançar o estado Started. Resumidamente, estes estados podem ser descritos da seguinte forma:

- Unrealized: estado em que se encontra um Player quando acaba de ser instanciado. Neste estado, o Player não possui nenhuma informação a respeito da mídia que irá apresentar; 
- Realizing: neste estado o Player está em processo de identificar quais recursos irá necessitar para a apresentação de seu stream de mídia. Para tanto, o Player faz um pré-carregamento de parte do stream para obter informações a respeito da mídia que irá apresentar;

- Realized: um Player alcança este estado quando, conhecendo o stream que deve apresentar, adquire todos os recursos de que necessita para apresentá-lo, com exceção dos recursos de uso exclusivo, que são aqueles que podem ser usados por apenas um Player em um dado instanțe;

- Prefetching: neste estado o Player realiza o carregamento em buffers locais do stream a ser apresentado e obtém recursos de uso exclusivo, como dispositivos que apresentam áudio, por exemplo;

- Prefetched: um Player alcança este estado quando está pronto para apresentar seu stream;

- Started: quando um Player alcança este estado, seu clock é ativado e o fluxo de dados do stream passa a ser processado à medida que o tempo transcorre.

Ao passar de um estado para outro, um Player gera eventos de transição (TransitionEvents). A Interface ControllerListener (abordada na Seção B.5) provê formas de se determinar em que estado um Player se encontra em um dado momento. Esta informação é importante porque a maioria dos métodos aplicáveis a um objeto Player só podem ser invocados em determinados estados. Quando um programa invoca um método ilegal para o estado corrente de um Player, o mesmo gera um erro ou uma exceção. A Tabela B.1 mostra as restriçõos existentes para a invocação dos principais métodos da interface Player. 
Tabela B.1 - Retriçōes à invocação de métodos em um Player [JMP97]

\begin{tabular}{|c|c|c|c|c|}
\hline Método & Unrealized & Realized & Prefetched Player & Started \\
\hline GetStartLatency & $\begin{array}{c}\text { NotRealized- } \\
\text { Error }\end{array}$ & legal & legal & legal \\
\hline getTimeBase & $\begin{array}{c}\text { NotRealized- } \\
\text { Error }\end{array}$ & legal & legal & legal \\
\hline setMediatime & $\begin{array}{c}\text { NotRealized- } \\
\text { Error }\end{array}$ & legal & legal & legal \\
\hline setrate & $\begin{array}{c}\text { NotRealized- } \\
\text { Error }\end{array}$ & legal & legal & legal \\
\hline $\begin{array}{l}\text { GetVisual- } \\
\text { Component }\end{array}$ & $\begin{array}{c}\text { NotRealized- } \\
\text { Erxor }\end{array}$ & legal & legal & legal \\
\hline $\begin{array}{l}\text { GetControlpanel- } \\
\text { Component }\end{array}$ & $\begin{array}{c}\text { NotRealized- } \\
\text { Error }\end{array}$ & legal & legal & legal \\
\hline getGaincontrol & $\begin{array}{l}\text { NotRealized- } \\
\text { Error }\end{array}$ & legal & legal & legal \\
\hline setStoptime & $\begin{array}{c}\text { NotRealized- } \\
\text { Error }\end{array}$ & legal & legal & $\begin{array}{l}\text { StoptimeSet- } \\
\text { Error }\end{array}$ \\
\hline syncstart & $\begin{array}{c}\text { NotPrefetched } \\
\text { Error }\end{array}$ & $\begin{array}{c}\text { NotPrefetched } \\
\text { Error }\end{array}$ & legal & $\begin{array}{c}\text { ClockStarted- } \\
\text { Error }\end{array}$ \\
\hline setTimeBase & $\begin{array}{c}\text { NotRealized- } \\
\text { Error }\end{array}$ & legal & legal & $\begin{array}{c}\text { Clockstarted- } \\
\text { Error }\end{array}$ \\
\hline deallocate & legal & legal & legal & $\begin{array}{c}\text { ClockStarted- } \\
\text { Error }\end{array}$ \\
\hline addController & $\begin{array}{c}\text { NotRealized- } \\
\text { Error }\end{array}$ & legal & legal & $\begin{array}{c}\text { Clockstarted- } \\
\text { Errox }\end{array}$ \\
\hline remove Controller & $\begin{array}{c}\text { NotRealized- } \\
\text { Error }\end{array}$ & legal & legal & $\begin{array}{c}\text { Clockstarted- } \\
\text { Error }\end{array}$ \\
\hline mapToTimeBase & $\begin{array}{c}\text { Clockstopped- } \\
\text { Exception }\end{array}$ & $\begin{array}{c}\text { Clockstopped- } \\
\text { Exception }\end{array}$ & $\begin{array}{c}\text { Clockstopped- } \\
\text { Exception }\end{array}$ & legal \\
\hline
\end{tabular}

\section{B.4. Funcionamento Básico de um Player}

O funcionamento básico de um Player é provido pelos métodos responsáveis pela transição de seus estados e pelo início e término da apresentação da mídia a ele associada. As interfaces Clock e Player definem os métodos usados para iniciar e parar um Player, enquanto que a interface Controller é responsável pela implementação dos métodos usados no gerenciamento de seus estados. 


\section{B.4.1. Iniciando e Parando um Player}

Em geral, inicia-se a apresentação de um Player invocando-se o método start. O método start faz com que o Player inicie a apresentação de sua mídia associada o mais rápido possível. No entanto, a maioria dos Players não podem ser iniciados instantaneamente. Antes que possam iniciar, algumas condições a nível de software e hardware devem ser satisfeitas. Por exemplo, se - Player nunca tiver sido iniciado, será provavelmente necessário alocar buffers de memória para armazenar os dados de sua mídia associada. Se esta mídia estiver armazenada em um servidor remoto, o Player deverá estabelecer uma conexão de rede para que possa fazer a recuperação do arquivo de mídia antes de iniciar a apresentação.

A API JMF Player divide o processo de preparação de um Player para iniciar em duas fases, chamadas Realizing e Prefetching. As atividades realizadas nestas duas fases minimizam o tempo gasto pelo Player para começar a apresentar sua mídia associada quando o método start é invocado, ou seja, estas atividades minimizam o tempo de latência para o início da apresentação.

Para iniciar a apresentação de uma mídia pode-se usar, além do start, o método syncStart. O syncStart é usado quando deseja-se iniciar duas ou mais mídias sincronamente. A Seção B.6 Gerenciamento de Temporização e Sincronização - aborda com detalhes a utilização do método syncStart.

É possível também iniciar a apresentação de um stream em um ponto específico do seu tempo de mídia. Para tanto, usa-se o método setMediaTime para ajustar o ponto do stream no qual desejase iniciar a apresentação. Em seguida, basta invocar o método start para que a apresentação inicie no ponto desejado.

Para interromper a apresentação de um Player invoca-se o método stop. No entanto, existem outras situações que causam a interrupção na apresentação de um Player. São elas:

- Quando o Player encontra um ponto de parada previamente especificado;

- Quando o buffer do Player fica vazio;

- Quando o Player recebe dados numa taxa muito baixa, impossibilitando que o mesmo mantenha a taxa de playback requerida pelo usuário; 
Para especificar um ponto de parada usa-se o método setStopTime. Para obter um ponto de parada previamente especificado usa-se o método getStopTime. Para remover um ponto de parada previamente especificado usa-se o métodò setStopTime com a opção UNSET, ou seja, setStopTime(UNSET).

\section{B.4.2. Gerenciando os Estados de Um Player}

Os métodos start e stop, já abordados, juntamente com os métodos realize, prefetch, deallocate e close são responsáveis por gerenciar a transição de estados de um Player. Para tanto, é necessário implementar a interface ControllerListener, que serve para invocar o método apropriado de acordo com as mudanças no estado do Player.

O gerenciamento dos estados de um Player é uma tarefa importantíssima, uma vez que a maioria dos métodos definidos para um Player só podem ser invocados em determinados estados de seu ciclo (ver Tabela B.1). Por exemplo, só é possível obter os componentes de um Player (componente visual, painel de controle, etc.) quando o mesmo já tiver concluído o processo de Realizing, ou seja, quando o Player receber o evento Realize CompleteEvent.

Gerenciando os estados de um Player é possível prepará-lo para iniciar a exibição de seu arquivo de mídia associado, determinar o tempo de latência para que ele inicie a apresentação e fazer a liberação dos recursos usados por ele, quando a apresentação estiver concluída.

\section{Determinando o Tempo de Latência de Início de um Player}

Para se determinar o tempo necessário para iniciar um Player deve-se invocar o método getStartLatency. Para Players que possuem um tempo de latência de início variável, o valor retornado pelo método getStartLatency representa o maior tempo de latência de início possível. Para alguns tipos de mídia, não é possível determinar o tempo de latência de início e, nestes casos, o método getStartLatency retorna LATENCY_UNKNOWN.

O tempo de latência de início pode variar de acordo com o estado em que o Player se encontra. Assim, um Player que já tenha terminado o processo de Prefetching certamente terá um tempo de latência de início menor que um outro que ainda esteja no processo de Prefetching ou Realizing. 


\section{Liberação de Recursos Usados pelo Player}

Após a apresentação de seu arquivo de mídia associado, um Player deve liberar os recursos utilizados na apresentação. O método deallocate tem a função de liberar todo recurso de uso exclusivo (placa de som, por exemplo) e minimizar o uso de recursos não exclusivos, como é o caso dos buffers de memória.

O método deallocate deve ser invocado quando o Player não estiver mais sendo usado. Um applet, por exemplo, deve chamar o método deallocate como parte de seu método stop. Quando um programa chama o método deallocate, ele libera recursos para uso do sistema, mas ainda mantém referências ao Player, podendo reiniciá-lo a qualquer momento.

O método close, ao contrário do método deallocate, deve ser chamado somente quando se tiver certeza que o Player não será mais executado. A chamada ao método close libera todos os recursos usados pelo Player, impossibilitando que ele seja reiniciado no futuro.

\section{B.5. A Interface ControllerListener}

Quando passa de um estado para outro, um Player gera eventos chamados TransitionsEvents. A ocorrência desses eventos pode ser capturada pela interface ControllerListener.

A interface ControllerListener é uma interface assíncrona usada para manipular eventos gerados por objetos do tipo Controller. Um Controller é um tipo mais simples de Player (Player é subclasse de Controller). O uso da interface ControllerListener permite gerenciar a temporização das operações de um Player que são potencialmente consumidoras de tempo, como Realizing e Prefetching.

A implementação da interface ControllerListener pela classe que está definindo um Player implica a correspondente implementação do método componente desta classe, chamado ControllerUpdate. Através da implementação deste método é feita a manipulação dos eventos gerados pelo Player.

O método ControllerUpdate é geralmente implementado como uma série de declaraçōes if-else, detectando os eventos que são de interesse para a aplicação e que serão por ela tratados. Assim, a 
organização básica do corpo do método ControllerUpdate pode ser representada pelo esquema mostrado na Figura B.4.

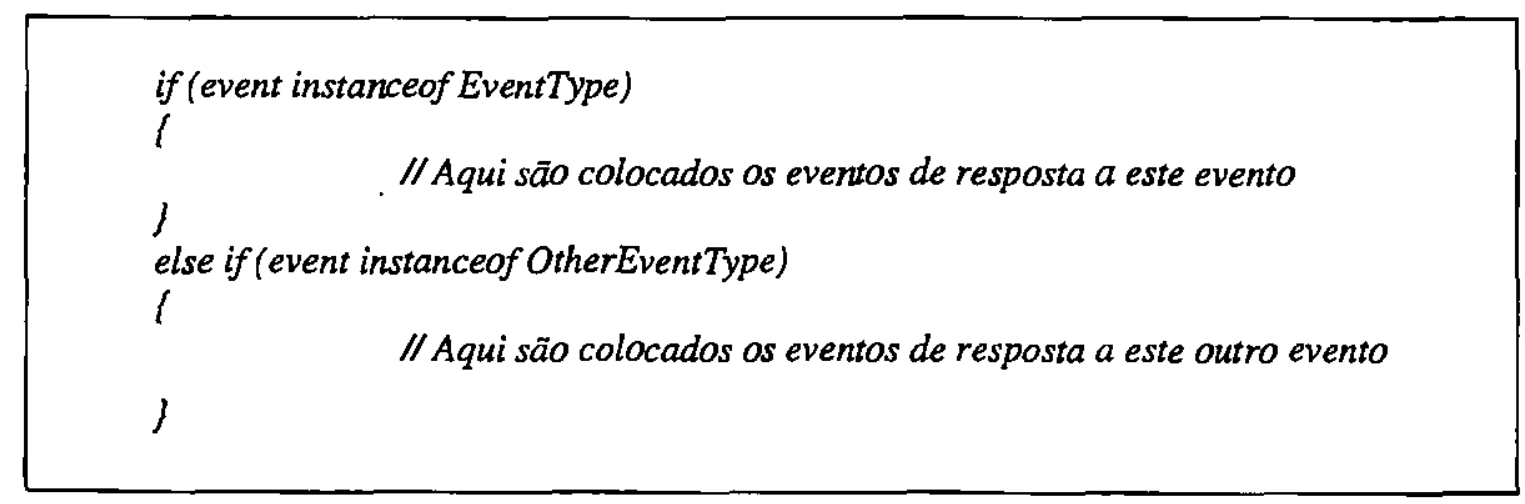

Figura B.4 - Corpo do método ControllerUpdate

Além da implementação da interface ControllerListener, é também necessária a invocação do método addControllerListener, especificando como listener dos eventos de controle do Player o próprio objeto da classe que define este Player. Esta sequiência de ações obedece ao novo modelo de eventos da API AWT, disponibilizada a partir da versão 1.1 do Java Development Kit (JDK 1.1).

A API AWT realiza um papel importante na apresentação de um Player, pois é ela que oferece a interface gráfica usada pelo Player para apresentar vídeos e interagir com o usuário. Dessa forma, pode-se, resumidamente, definir que a apresentação de um Player é coordenada pelo modelo de temporização do JMF Player, enquanto que os componentes de interface são apresentados usando-se o pacote AWT. Neste contexto, é possível distinguir duas categorias básicas de componentes AWT em um Player:

- Componente Visual: onde o Player efetivamente apresenta seu stream de mídia. Só existe se o stream a ser apresentado possuir um componente de vídeo; 
- Componentes de Controle: conjunto de botões, sliders e outros objetos integrantes do pacote AWT, que compõem um painel de controle permitindo ao usuário interagir com a mídia que está sendo apresentada pelo Player.

A interface ControllerListener é capaz de notificar, através de seu método ControllerUpdate, uma série de eventos que possibilitam monitorar o estado de um Player e capturar o resultado das interações que o usuário realiza em seus componentes de controle. Assim, o método ControllerUpdate recebe notificações tanto de eventos assíncronos gerados internamente pelo próprio Player, como também eventos assíncronos gerados através da interação do usuário com o painel de controle do Player.

De modo geral, a invocação de qualquer método em um Player tem como resultado a geração de um evento. Assim, quando se invoca o método Start() em um Player, o evento StartEvent será gerado, a não ser que o Player não possa ser iniciado. Neste caso, um evento de erro será gerado.

\section{B.6. Gerenciamento de Temporização e Sincronização}

As interfaces TimeBase e Clock, providas pela API JMF Player, definem mecanismos para gerenciamento de temporização e sincronização de mídias. Para tanto, estas interfaces utilizam os conceitos de tempo base (time-base time) e tempo de mídia (media time).

O tempo base representa um fluxo de tempo contínuo que não pode ser alterado. $O$ tempo de mídia, por outro lado, representa um ponto no tempo do stream que o Player está apresentando. Tal ponto serve para referenciar of frame que está sendo correntemente apresentado pelo Player, ou seja, o tempo de mídia tem a finalidade de indicar a posição temporal do frame corrente com relação ao tempo total de um stream de mídia contínua que está sendo apresentado. A interface Clock define um mapeamento entre o tempo de mídia e o tempo base. Este mapeamento é mostrado na Figura B.5. 


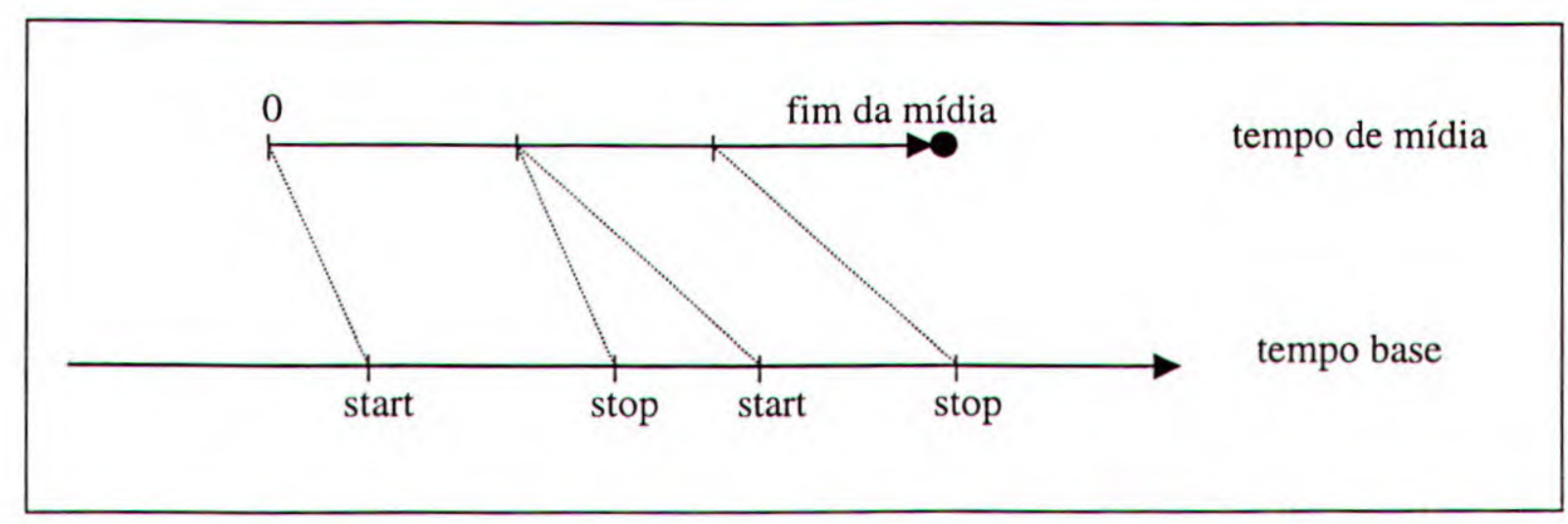

Figura B.5 - Mapeamento entre o tempo de mídia e o tempo base [JMP97]

Observando a Figura B.5, nota-se que a invocação do método stop() só paralisa o tempo de mídia; o tempo base continua a evoluir. O tempo base é geralmente fornecido pelo System Clock e medido em nanosegundos, podendo ser acessado através do método Manager.getSystemTimeBase.

Não são somente os métodos start e stop que modificam o valor do tempo de mídia. Através da invocação do método setMediaTime pode-se acessar qualquer ponto de um stream. É perfeitamente possível, portanto, iniciar a apresentação de um stream em qualquer ponto do seu tempo de mídia. De forma análoga, pode-se também ajustar o tempo de término da apresentação de um stream, usando como referência seu tempo de mídia. Para tanto basta usar o método setStopTime.

Em qualquer ponto da apresentação de um stream é possível obter o tempo de mídia e o tempo base correntes. Para tanto basta usar os métodos getMediaTime e getTimeBaseTime, respectivamente. A API JMF provê ainda métodos para se ajustar a taxa de apresentação de um stream (setRate) e para se conhecer a duração de um stream (getDuration), desde que o mesmo já tenha terminado seu processo de Prefetching.

A API JMF Player provê, ainda, facilidades para realizar a sincronização de dois ou mais Players. Existem duas formas de se realizar esta sincronização. A primeira delas consiste no controle manual da sincronização. A segunda, mais eficiente, consiste no uso de um Player para 
gerenciar e sincronizar outros Players. A implementação dessas duas formas de sincronização é descrita a seguir.

- Sincronização manual de Players: para realizar a sincronização manual de Players, basta fazer com que o tempo base de todos os Players que se deseja sincronizar seja o mesmo e invocar o método Syncstart em todos os Players, levando em consideração o maior tempo de latência entre os Players envolvidos na sincronização. Para utilizar este esquema de sincronização é necessário capturar os eventos de transição gerados por cada Player envolvido na sincronização, uma vez que o método SyncStart só pode ser invocado em Players que tenham terminado o estado de Prefetching. De forma similar, é necessário capturar em todos os Players os eventos que respondem à invocação de um método, a fim de certificar que todos eles executaram corretamente o método invocado.

- Sincronização através do uso de um Player gerente: neste esquema, um Player é escolhido como gerente de um grupo de Players envolvidos em uma mesma apresentação sincronizada. As interações realizadas com o Player gerente são automaticamente repassadas aos demais Players, que, ao se subordinarem a um Player gerente, passam a ser chamados de Controllers. Através dos métodos addController e removeController, invocados no Player gerente, novos Players podem ser adicionados e removidos da lista de Controllers. Quando um Player passa a gerenciar um Controller, as seguintes ações são realizadas:

- O Controller assume o tempo base do Player;

- A duração do Player se torna a maior duração entre a sua e a de todos os Controllers sob sua gerência.

- O tempo de latência do Player se torna o maior tempo de latência entre o seu e o de todos os Controllers sob sua gerência.

Neste esquema de sincronização, a invocação de um método no Player gerente é propagada por ele para os Controllers de forma apropriada. Assim, antes de repassar a invocação de um método para um Controller, o Player gerente se certifica que o mesmo está em um estado adequado para execução do referido método. 